\title{
Leren werken in het Nederlandse beroepsonderwijs : Vraag- en aanbodontwikkelingen voor de BBL 1999- 2004
}

Citation for published version (APA):

Borghans, L., Smits, W., Vlasblom, J. D., \& Jacobs, A. E. J. P. (2000). Leren werken in het Nederlandse beroepsonderwijs : Vraag- en aanbodontwikkelingen voor de BBL 1999-2004. Researchcentrum voor Onderwijs en Arbeidsmarkt, Faculteit der Economische Wetenschappen. ROA Reports No. 2 https://doi.org/10.26481/umarep.2000002

Document status and date:

Published: 01/01/2000

DOI:

10.26481/umarep.2000002

Document Version:

Publisher's PDF, also known as Version of record

Please check the document version of this publication:

- A submitted manuscript is the version of the article upon submission and before peer-review. There can be important differences between the submitted version and the official published version of record.

People interested in the research are advised to contact the author for the final version of the publication, or visit the DOI to the publisher's website.

- The final author version and the galley proof are versions of the publication after peer review.

- The final published version features the final layout of the paper including the volume, issue and page numbers.

Link to publication

\footnotetext{
General rights rights.

- You may freely distribute the URL identifying the publication in the public portal. please follow below link for the End User Agreement:

www.umlib.nl/taverne-license

Take down policy

If you believe that this document breaches copyright please contact us at:

repository@maastrichtuniversity.nl

providing details and we will investigate your claim.
}

Copyright and moral rights for the publications made accessible in the public portal are retained by the authors and/or other copyright owners and it is a condition of accessing publications that users recognise and abide by the legal requirements associated with these

- Users may download and print one copy of any publication from the public portal for the purpose of private study or research.

- You may not further distribute the material or use it for any profit-making activity or commercial gain

If the publication is distributed under the terms of Article 25fa of the Dutch Copyright Act, indicated by the "Taverne" license above, 


\title{
Leren en werken in het Nederlandse beroepsonderwijs
}

Vraag- en aanbodontwikkelingen voor de BBL 1999-2004

ROA-R-2000/2

\author{
L. Borghans \\ W. Smits \\ J.D. Vlasblom \\ A. Jacobs
}

Researchcentrum voor Onderwijs en Arbeidsmarkt

Faculteit der Economische Wetenschappen en Bedrijfskunde Universiteit Maastricht

Maastricht, december 1999 
ISBN 90-5321-273-6

Sec99.180/LB 


\section{Inhoudsopgave}

Bladzijde

Voorwoord

1. Inleiding 1

2. De vraag naar BBL-leerlingen 5

2.1 Inleiding 5

2.2 Waarom nemen bedrijven BBL-leerlingen in dienst?

Korte- versus lange-termijn motieven 5

2.3 De empirische relevantie van korte- en lange-termijn motieven

2.5 Het effect van werkgelegenheidsgroei op de vraag naar $\begin{array}{ll}B B L-\text { en BOL-leerlingen } & 23\end{array}$

3. De vraag naar gediplomeerden uit de BBL $\quad 27$

$\begin{array}{ll}3.1 \text { Inleiding } & 27\end{array}$

3.2 Waarom nemen bedrijven BOL'ers of BBL'ers in dienst? 28

$\begin{array}{ll}3.3 \text { Voorkeuren van werkgevers } & 30\end{array}$

3.4 De voorkeuren van werkgevers nader bekeken:
de garagesector en de zorg

4. Het aanbod van leerlingen en gediplomeerden 39

$\begin{array}{ll}4.1 \text { Inleiding } & 39\end{array}$

4.2 Leerlingen in opleiding 39

4.3 Het aanbod van leerlingen naar opleidingstype $\quad 40$

4.4 Het aanbod van gediplomeerden naar opleidingstype 42

$\begin{array}{ll}\text { 5. Confrontatie van vraag en aanbod } & 49\end{array}$

5.1 Inleiding 49

5.2 De actuele situatie op de arbeidsmarkt $\quad 49$

$\begin{array}{ll}5.3 \text { Beschikbaarheid van bpv-plaatsen } & 50\end{array}$

5.4 Prognoses voor de vraag naar onderwijsverlaters van de
BOL en de BBL

5.5 Perspectieven voor BOL en BBL 56

6. Conclusies $\quad 59$

$\begin{array}{ll}\text { Literatuur } & 63\end{array}$

$\begin{array}{ll}\text { Appendix: De bedrijfsenquête } & 67\end{array}$ 



\section{Voorwoord}

In het hoofdlijnenakkoord inzake versterking werkend leren (Werkend leren is kansen creëren) tussen het Ministerie van Onderwijs, Cultuur en Wetenschappen, het Ministerie van Sociale Zaken en Werkgelegenheid en de sociale partners is afgesproken dat een nadere analyse plaats dient te vinden naar de mogelijkheden om het concept werkend leren te versterken. In dit rapport wordt - in opdracht van het Ministerie van Onderwijs, Cultuur en Wetenschappen - ingegaan op de positie van leerlingen en gediplomeerden van de $B B L$ op de arbeidsmarkt en de ontwikkelingen in vraag en aanbod zoals die voor de periode 1999-2004 worden voorzien.

De auteurs zijn de heren C. Hoogendijk van MKB Nederland en R. Roelofse van het CNV erkentelijk voor hun commentaar in de begeleidingsgroep van dit onderzoek. 


\section{Inleiding}

De meeste beroepskwalificaties op middelbaar niveau kunnen zowel via de beroepsopleidende leerweg (BOL) als de beroepsbegeleidende leerweg (BBL) worden behaald. Momenteel wordt getracht de BBL te versterken (zie: Werkend leren is kansen creëren: hoofdlijnenakkoord inzake versterking werkend leren). Omdat de $B B L$ reeds tijdens het leertraject zeer sterk is gekoppeld aan de arbeidsmarkt is het voor gerichte beleidsmaatregelen ter versterking van de BBL noodzakelijk om een helder inzicht te verkrijgen in de arbeidsmarktpositie van deze leerweg. Het gaat dan zowel om het aanbod van en de vraag naar beroepspraktijkvormingsplaatsen (de markt voor bpv-plaatsen voor leerlingen van de BBL) als de mogelijkheden die de arbeidsmarkt biedt na afloop van het leertraject (de arbeidsmarkt voor onderwijsverlaters van de $\mathrm{BBL}$ ). De ontwikkelingen op beide markten hangen nauw samen. Zowel het aanbod van beroepspraktijkvormingsplaatsen als de vraag naar gekwalificeerde vakmensen vanuit verschillende beroepsgroepen zijn sterk afhankelijk van de arbeidsmarktontwikkelingen in deze beroepsgroepen.

Het aanbod van beroepspraktijkvormingsplaatsen door bedrijven zal echter niet alleen door deze actuele werkgelegenheidsontwikkeling worden bepaald, maar ook door de (verwachte) toekomstige vraag naar personen die een opleiding via de BBL hebben afgerond. Sommige bedrijven leiden immers leerlingen op met het oog op een toekomstige behoefte aan gekwalificeerd personeel. De ontwikkeling in het aantal beroepspraktijkvormingsplaatsen kan daarom niet los worden gezien van de toekomstige vraag naar onderwijsverlaters van de BBL, maar er is ook zeker geen sprake van een één-op-één relatie. Ten eerste zijn er bedrijven die wel behoefte hebben aan gekwalificeerd personeel maar niet zelf leerlingen opleiden. Ten tweede kunnen ook verschillende niet-economische factoren een rol spelen bij de beslissing om een beroepspraktijkvormingsplaats in te stellen.

Ontwikkelingen bij de BBL kunnen daarnaast niet los worden gezien van de ontwikkelingen bij verwante opleidingen bij de BOL en de rest van de arbeidsmarkt. Interactie tussen beide leerwegen komt zowel voor aan het begin als na afloop van het leertraject. Hierbij geldt dat er zowel voor werkgevers als voor leerlingen mogelijkheden bestaan tot substitutie tussen de BBL en de BOL. Werkgevers kunnen bij het beschikbaar stellen van beroepspraktijkvormingsplaatsen een afweging maken tussen een leerplaats voor de BBL of andere mogelijkheden om in hun huidige en toekomstige personeelsbehoefte te voorzien. Ze kunnen bijvoorbeeld een stageplaats voor iemand van de BOL aanbieden of ongeschoold personeel aannemen. Verwacht wordt dat in de meeste sectoren bedrijven heel andere overwegingen hebben bij het instellen van een stageplaats dan bij het aanbieden van een beroepspraktijkvormingsplaats voor de BBL. In het laatste geval hebben leerlingen naast een leercontract meestal ook een arbeidscontract en zijn ze ook direct productief inzetbaar. Toch kunnen bedrijven, als stagiaires relatief goedkoop zijn ten opzichte van leerlingen via de BBL, stagiaires als substituut voor leerlingen gaan zien. De substitutiemogelijkheden die werkgevers hebben tussen BBL en BOL na 
afloop van de opleiding zijn mogelijk groter dan tijdens de opleiding. Daar beide leerwegen in principe opleiden tot gelijke kwalificaties kunnen naar verwachting veel vacatures door schoolverlaters van beide leerwegen worden vervuld. Hierdoor hebben tekorten of overschotten bij de ene leerweg invloed op de ontwikkelingen bij de andere leerweg. Beide groepen hebben een grotendeels overlappend beroependomein en hebben dus een gezamenlijke deelmarkt. Vaak zal bij bedrijven echter wel sprake zijn van een zekere voorkeur voor één van beide leerwegen. Deze voorkeuren houden waarschijnlijk verband met de bedrijfstak en het vakgebied. Natuurlijk zullen bij de afweging ook andere factoren dan de leerweg, zoals persoonskenmerken van kandidaten, een rol spelen. Ook leerlingen kunnen kiezen tussen de $B O L$ en de $B B L$, en als gevolg van de omstandigheden besluiten een andere variant te kiezen. Zo zal een deel van de leerlingen die in eerste instantie een opleiding via de BBL wilden gaan doen maar geen bpv-plaats heeft kunnen krijgen, mogelijk alsnog voor de BOL kiezen. Het is echter ook mogelijk dat personen die geen beroepspraktijkvormingsplaats hebben kunnen vinden van de opleiding afzien en kiezen voor een werkplek zonder opleidingscomponent.

De overwegingen die bedrijven hebben bij het aannemen van leerlingen kunnen van invloed zijn op de inhoud van de opleidingen. De gedachte is dat als een bedrijf de leerlingen nu nodig heeft om een personeelskrapte op te lossen, dit bedrijf er bij gebaat is om het opleidingsgedeelte beperkt te houden, maar daarnaast ook om deze opleiding zeer specifiek te richten op de uit te voeren productieve taken. Als een bedrijf gebaat is bij een goed opgeleide werknemer op termijn, dan zal deze balans waarschijnlijk meer in evenwicht zijn.

In dit rapport wordt de arbeidsmarkt voor de BBL nader geanalyseerd. Voor de verdere versterking van de $B B L$ is het van belang om zicht te hebben op de redenen waarom bedrijven leerplaatsen beschikbaar stellen en de afwegingen die ze maken bij in dienst houden of het werven van gediplomeerden van de BBL. Daarnaast is een goed beeld van vraag- en aanbodontwikkelingen op zowel de markt voor bpvplaatsen als de arbeidsmarkt voor gekwalificeerde onderwijsverlaters van de BBL van groot belang. Dit rapport geeft antwoord op de volgende vier vragen:

1. Welke afwegingen maken werkgevers bij het beschikbaar stellen van bpvplaatsen voor BBL-leerlingen?

2. Welke afwegingen maken werkgevers bij het werven c.q. in dienst houden van gekwalificeerde onderwijsverlaters van de BBL?

3. Wat zijn de verwachte ontwikkelingen tot 2004 met betrekking tot de markt voor bpv-plaatsen?

4. Wat zijn de verwachte ontwikkelingen tot 2004 met betrekking tot de arbeidsmarkt voor gekwalificeerde onderwijsverlaters van de BBL?

Deze vragen zijn uiteraard sterk aan elkaar gerelateerd. Om te kunnen analyseren welke ontwikkelingen te verwachten zijn met betrekking tot het beschikbaar stellen van bpv-plaatsen (vraag 3 ) is ook een beeld nodig van de afwegingen die werkgevers op dit punt maken (vraag 1). Het aanbod van bpv-plaatsen is verder 
afhankelijk van de ontwikkeling van vraag en aanbod op de arbeidsmarkt (vraag 4). Bij de beantwoording van de vraag hoe de vraag naar onderwijsverlaters van de BBL zich de komende jaren ontwikkelt (vraag 4), is, zoals reeds werd opgemerkt, inzicht in het afwegingsproces van de werkgever onontbeerlijk (vraag 2).

Er zullen zowel voor beroepspraktijkvormingsplaatsen als voor schoolverlaters van de $B B L$ vraag- en aanbodprognoses worden gemaakt. Voor het maken van prognoses voor de vraagzijde van de arbeidsmarkt voor de BBL (de vraag naar leerlingen ofwel het aanbod van beroepspraktijkvormingsplaatsen en de vraag naar onderwijsverlaters van de $\mathrm{BBL}$ ) moet in eerste instantie een duidelijk inzicht worden verkregen in de factoren die van invloed zijn op de vraag. Hierbij is het ook van belang om na te gaan in welke mate werkgevers de BBL en de BOL als elkaars substituut zien. Er moet dan zowel worden gekeken naar de substitutiemogelijkheden die werkgevers hebben bij aanvang van de opleiding als bij intrede op de arbeidsmarkt na afloop van de opleiding. Ook de mate waarin leerlingen beide leerwegen als elkaars substituut zien moet worden onderzocht. Voor een analyse van de vraagzijde van de markt is een (telefonische) enquête onder werkgevers gehouden. Daarnaast is voor een analyse van de aanbodzijde gebruik gemaakt van meerdere jaargangen van de schoolverlatersenquête RUBS.

Een goed inzicht in bovengenoemde aspecten van de arbeidsmarkt voor de BBL maakt het ook mogelijk om ervaren tekorten aan beroepspraktijkvormingsplaatsen kritisch te evalueren. Bij het evalueren van deze tekorten zijn namelijk meerdere invalshoeken mogelijk. Als de vraag naar beroepspraktijkvormingsplaatsen het aanbod overtreft heeft dit nadelige gevolgen voor de mogelijkheid een dergelijke opleiding te volgen. In dat geval heeft immers niet iedereen die de opleiding wil gaan volgen toegang tot de meest wezenlijke component van de opleiding. Daarbij is tevens van belang in hoeverre het tekort aan beroepspraktijkvormingsplaatsen bij de $\mathrm{BBL}$ kan worden opgevangen door een toename van de instroom in de BOL. Vanuit economisch oogpunt is er alleen sprake van een tekort als het beperkte aanbod van beroepspraktijkvormingsplaatsen in de toekomst zal leiden tot een tekort aan gekwalificeerd personeel. Bovenstaande maakt duidelijk dat het voor het voeren van een adequaat beleid van belang is, dat bekend is wat de achtergrond van de ervaren tekorten aan beroepspraktijkvormingsplaatsen is.

Dit rapport is als volgt opgebouwd. In hoofdstuk 2 wordt ingegaan op de afwegingen die ten grondslag liggen aan het beschikbaar stellen van bpv-plaatsen: de vraag naar leerlingen. De resultaten in dit hoofdstuk zijn grotendeels gebaseerd op de telefonische enquête onder bedrijven. In hoofdstuk 3 wordt vervolgens ingegaan op het afwegingsproces van werkgevers bij het in dienst nemen/houden van onderwijsverlaters van de BBL. Met name de positie van de $B B L$ ten opzichte van de $B O L$ komt hierbij aan de orde. Ook hierbij is de telefonische enquête onder bedrijven de belangrijkste bron. In aanvulling daarop wordt voor een tweetal sectoren - de garagesector en zorginstellingen - aanvullende informatie gegeven op basis van een vignetonderzoek. In hoofdstuk 4 wordt ingegaan op het aanbod van leerlingen voor de $B B L$ en het aanbod van gediplomeerden met een kwalificatie op het niveau van 
het secundair beroepsonderwijs. In hoofdstuk 5 wordt ingegaan op de ontwikkelingen in de vraag naar opgeleiden uit het secundair beroepsonderwijs in zijn algemeenheid en BBL'ers in het bijzonder. In dit hoofdstuk wordt tevens ingegaan op de verwachte ontwikkelingen in het aanbod van bpv-plaatsen. Hoofdstuk 6 ten slotte geeft een overzicht van de belangrijkste bevindingen in dit rapport. 


\section{De vraag naar BBL-leerlingen}

\subsection{Inleiding}

In dit hoofdstuk wordt ingegaan op de afwegingen die spelen bij het beschikbaar stellen van bpv-plaatsen door bedrijven. Om vanuit een macrodoelmatigheidsperspectief de aansluiting tussen de BBL en de arbeidsmarkt zo goed mogelijk te laten verlopen, zou in een ideale situatie de beschikbaarheid van bpv-plaatsen af moeten hangen van de verwachte toekomstige vraag in de sector. Omdat leerlingen voor een groot deel van hun werktijd betrokken zijn bij het productieproces en bedrijven de activiteiten van de leerling in zullen moeten passen in de bedrijfsvoering, zullen actuele ontwikkelingen in het bedrijf echter een belangrijke determinant zijn van de vraag naar leerlingen. Daarnaast zullen bedrijven ook bpv-plaatsen beschikbaar stellen vanuit de toekomstige behoefte aan personeel. Omdat het hier gaat om de personeelsbehoefte van het bedrijf zelf en niet om de behoefte van de sector als geheel kan ook hier een spanning tussen gewenste en beschikbare hoeveelheid bpv-plaatsen ontstaan.

\subsection{Waarom nemen bedrijven BBL-leerlingen in dienst? Korte- versus lange- termijn motieven}

Bedrijven kunnen verschillende motieven hebben om BBL-leerlingen in dienst te nemen. In de economische literatuur wordt meestal een onderscheid gemaakt tussen korte- en lange-termijn motieven (zie bijvoorbeeld, Borghans en Smits, 1997 en Smits, 1997, Lindley, 1975 en Stevens, 1994).

Korte-termijn motieven hebben betrekking op de periode van de leeraanstelling. Die is in Nederland in de regel twee jaar. Meestal leveren BBL-leerlingen al tijdens de leerperiode een positieve bijdrage aan de productie van een bedrijf. Dat betekent dat tegenover het salaris en de kosten van het begeleiden van leerlingen ook baten in de vorm van productiviteit staan. In sommige bedrijven is het productieproces zelfs zo ingericht dat leerlingen een vast aandeel in de productie hebben. De vraag naar BBL-leerlingen kan in dat geval direct gekoppeld worden aan de huidige personeelsbehoefte. Als louter korte-termijn motieven van belang zijn, betekent dit dat de directe baten in de vorm van geleverde productiviteit van leerlingen de kosten, zoals begeleiding en salaris overtreffen.

Daarnaast kan een bedrijf ook lange-termijn motieven hebben bij het opleiden van BBL-leerlingen. Wellicht zijn de directe baten van een leerling in de vorm van zijn productiviteit niet hoog genoeg om de gemaakte kosten onmiddellijk te dekken. Het bedrijf zou dan toch voordeel kunnen hebben omdat deze investering bijdraagt aan de toekomstige behoefte aan geschoold personeel. Lange-termijn motieven hebben dus betrekking op de periode na de opleiding. Dit onderscheid tussen korte- en lange-termijn motieven is vanuit twee perspectieven essentieel. 
In de eerste plaats is de leeromgeving in een bedrijf veel minder gestructureerd dan op school. Hoewel de kwalificatiestructuur eisen oplegt aan de inhoud van het onderwijs en bedrijven een erkenning als leerbedrijf moeten krijgen is het bij deze vorm van praktijkleren moeilijk om van buitenaf de kwaliteit van het onderwijs te optimaliseren. De waarde van de leeromgeving hangt immers sterk af van de aard van de opdrachten die een leerling krijgt en de feedback die hij hierbij ontvangt. Een bedrijf dat zelf ook belang heeft bij een goede opleiding van de leerlingen, omdat beoogd is dat de leerlingen bij het bedrijf in dienst blijven, vormt daarom een extra garantie voor een kwalitatief hoogstaande leeromgeving (zie ook Borghans en Smits, 1997).

In de tweede plaats is het aanbod van bpv-plaatsen conjunctuurgevoelig (zie bijvoorbeeld ROA, 1997). Vanuit een macrodoelmatigheidsperspectief zou wenselijk zijn dat het aantal beschikbare plaatsen afgestemd is op de toekomstige vraag naar geschoold personeel. Als de drijfveer van bedrijven is om te voorzien in een toekomstige personeelsbehoefte wordt deze kwantitatieve aansluiting voor hun eigen bedrijf optimaal bevorderd. Discrepanties tussen de gewenste hoeveelheid bpv-plaatsen en de werkelijke hoeveelheid bpv-plaatsen kunnen ontstaan doordat er ook vraag naar gediplomeerde BBL'ers zal zijn vanuit bedrijven die zelf niet bijdragen aan de opleiding en doordat naast deze lange-termijn motieven ook kortetermijn motieven de beschikbaarheid van bpv-plaatsen zullen beïnvloeden. Als bedrijven met name BBL-leerlingen aannemen op basis van korte-termijn motieven valt daardoor een anticyclisch opleidingsbeleid te vrezen. Bij een tijdelijke opleving van de vraag zullen BBL-leerlingen worden aangenomen die als ze eenmaal gediplomeerd zijn wellicht te maken krijgen met een terugvallende vraag.

Zowel de kwalitatieve als de kwantitatieve aansluiting van de BBL op de arbeidsmarkt is het meest gebaat bij bedrijven die leerlingen aannemen uit lange-termijn motieven. In de economische literatuur worden echter veel vraagtekens gezet bij deze lange-termijnmotieven van bedrijven. Het is immers de vraag waarom bedrijven bereid zouden zijn om opleidingskosten te maken die zij pas later terug kunnen verdienen. Ze zouden immers ook kunnen overwegen om direct gekwalificeerd personeel op de markt te werven. Bovendien loopt een bedrijf het risico dat intern opgeleide werknemers worden weggekocht door andere bedrijven. De afgelopen decennia zijn talrijke publicaties over deze problematiek verschenen. De meest invloedrijke publicatie is na 35 jaar nog steeds het artikel human capital van G.S. Becker (1964), die hiervoor onlangs de nobelprijs kreeg. In dit artikel maakt Becker onderscheid tussen wat hij aanduidt als algemene en bedrijfsspecifieke training. Volledig algemene training leidt tot kennis en vaardigheden die van nut zijn voor veel bedrijven buiten het leerbedrijf terwijl volledig bedrijfsspecifieke training alleen van nut is in het leerbedrijf. Hoewel deze theorie in de literatuur inmiddels op allerlei facetten is uitgebreid en aangepast, vormt dit onderscheid tussen bedrijfsspecifieke en algemene training nog steeds het uitgangspunt voor analyses van het opleidingsgedrag van bedrijven. Ook in de politieke discussie rond de invoering van de WEB speelde deze notie impliciet een rol bij het vaststellen van de rol die de overheid heeft bij het bekostigen van training: Opleidingen zouden 
voldoende 'breedte' moeten hebben en niet moeten leiden tot kennis en vaardigheden die alleen in een specifieke functie van belang zijn.

De economische theorie laat zien dat onder volledige concurrentie om gekwalificeerde werknemers het marktloon van een werknemer gelijk is aan zijn (marginale) productiviteit. Algemene training leidt daarom onder dergelijke omstandigheden altijd tot een stijging van het marktloon. Het leerbedrijf kan een intern opgeleide werknemer niet minder betalen dan zijn marktloon omdat deze werknemer dit loon elders wel kan krijgen. Dit betekent dat de opbrengsten van algemene training volledig ten goede komen aan de leerling. Het leerbedrijf heeft geen lange-termijn-opbrengsten, ongeacht of de leerling blijft of niet. Werkgevers zullen, volgens Becker, om deze reden niet bereid zijn om voor training te betalen, maar, zo beargumenteerde hij, dit is geen probleem omdat leerlingen zelf bereid zullen zijn de kosten te dragen.

Bedrijfsspecifieke training leidt daarentegen niet tot een hoger marktloon. Immers, als een leerling na afloop van de opleiding het leerbedrijf verlaat kan hij elders zijn opleiding niet te gelde maken. Het bedrijf kan de intern opgeleide werknemer daarom minder betalen dan zijn productiviteit. Echter, als de leerling na afloop van de opleiding het leerbedrijf verlaat verliest het leerbedrijf zijn investering. Het leerbedrijf zal daarom de leerling iets meer betalen dan zijn marktloon. De opbrengsten van bedrijfsspecifieke training gaan dus gedeeltelijk naar het leerbedrijf en gedeeltelijk naar de leerling. Om die reden zullen beide bereid zijn ook een deel van de kosten te dragen. Algemene training wordt dus geheel door de leerling betaald terwijl de kosten van bedrijfsspecifieke training worden gedeeld.

Training in het kader van de BBL leidt tot algemeen erkende beroepskwalificaties. Dit zijn kwalificaties die niet alleen van belang zijn in het leerbedrijf maar ook in andere bedrijven waar het betreffende beroep uitgeoefend kan worden. Volgens de definitie van Becker is training in het kader van de BBL dus grotendeels algemeen. Dit zou betekenen dat bedrijven geen lange-termijn belangen hebben bij het beroepsbegeleidend onderwijs en alleen meewerken als de leerlingen of de overheid de opleiding zelf volledig betalen, of als er voldoende korte-termijn baten zijn.

Het werk van Becker heeft grote invloed gehad op het overheidsbeleid in met name Engeland. Het leidde tot de conclusie dat bedrijven niet meer gestimuleerd hoefden te worden om werknemers op te leiden en daarmee tot de afbraak van het leerlingwezen (zie Stevens, 1994, 1996). In de loop der jaren is er een hele reeks van artikelen verschenen die proberen aan te tonen waarom Becker's analyse niet altijd opgaat en waarom bedrijven wel degelijk lange-termijn baten kunnen hebben bij het opleiden van BBL-leerlingen.

Ten eerste kunnen bedrijven de BBL gebruiken om de beste werknemers te selecteren (zie Franz en Soskice, 1995, Acemoglu en Pischke, 1998). Tijdens de leerperiode leert het bedrijf de kwaliteiten van individuele werknemers kennen, andere bedrijven kennen deze kwaliteiten niet. Aan het eind van de leerperiode 
krijgen de beste leerlingen een vervolgaanstelling aangeboden tegen het marktloon. Het marktloon is echter gebaseerd op de gemiddelde productiviteit van werknemers met deze opleiding, de productiviteit van de beste leerlingen zal iets hoger liggen dan gemiddeld. Het verschil tussen het loon en de productiviteit komt ten goede aan het leerbedrijf. Uit empirisch onderzoek in Duitsland blijkt dat dit argument vooral voor de grote bedrijven een grote rol speelt. Grote bedrijven kunnen het zich immers permitteren om meer leerlingen op te leiden dan ze in de toekomst nodig hebben, voor kleine bedrijven is dit veel moeilijker (zie ook Van Lieshout, 1996).

Een ander argument dat uit de literatuur naar voren komt is onvolledige informatie over de kwaliteit van de opleiding die iemand bij een ander bedrijf heeft gehad (Katz en Ziderman, 1990, en Chang en Wang, 1996). Andere bedrijven weten niet precies hoeveel training iemand heeft gehad en zijn dus niet bereid om een hoog loon te betalen aan werknemers die elders zijn opgeleid. Dit beperkt de mobiliteit van intern opgeleide werknemers. Het leerbedrijf kan hiervan profiteren door deze werknemers een loon betalen dat iets lager is dan de productiviteit. In Nederland zijn opleidingen in het kader van de BBL echter voor een belangrijk deel extern gelegitimeerd. Voor zover de kennis en vaardigheden die in een bepaald beroep van belang zijn ook daadwerkelijk in examens getoetst is, zal er dus geen onduidelijkheid bestaan over de kwaliteiten van de betreffende medewerkers. Werkgevers zullen daarom, zo valt te verwachten, over het algemeen niet al te veel twijfels hebben over de kwaliteit van de opleiding die werknemers elders genoten hebben.

Hoewel de BBL er op gericht is om algemeen erkende beroepsgerichte vaardigheden bij te brengen zal het onontkoombaar zijn dat ook enkele bedrijfsspecifieke vaardigheden worden geleerd. Een bedrijf heeft zijn eigen machines die wellicht niet door veel andere bedrijven worden gebruikt. Daarnaast is kennis van de bedrijfscultuur ook van essentieel belang voor het functioneren in een bedrijf. lemand die intern is opgeleid zal dit gelijk oppikken terwijl een extern opgeleide werknemer zich dit nog eigen moet maken (Franz en Soskice 1995, Acemoglu en Pischke 1999). De mogelijkheid om BBL-leerlingen naast algemeen erkende vaardigheden ook bedrijfsspecifieke kennis bij te brengen kan voor veel bedrijven een reden zijn om BBLleerlingen op te leiden. Ten slotte zijn werknemers in de praktijk ook minder mobiel dan in veel economische theorieën wordt aangenomen. Werknemers ontwikkelen een band met hun bedrijf, gaan in de buurt wonen etc., waardoor er feitelijk een drempel ontstaat om van baan te wisselen. Dergelijke drempels bieden bedrijven de ruimte om ook investeringen in algemene training op langere termijn terug te verdienen.

Er zijn dus verschillende argumenten waarom bedrijven wel degelijk lange-termijn belangen kunnen hebben bij het opleiden van BBL-leerlingen. Overigens sluiten korte- en lange-termijn motieven elkaar niet uit, meestal zullen beide factoren een rol spelen. Tenslotte kunnen ook niet-economische motieven - zoals liefde voor het vak - een rol spelen bij het opleiden van BBL-leerlingen. In de volgende paragrafen zal na worden gegaan in welke mate korte- en lange-termijn motieven een rol spelen voor het opleidingsbeleid van Nederlandse bedrijven. 


\subsection{De empirische relevantie van korte- en lange-termijn motieven}

In deze paragraaf zal op basis van de resultaten van de enquête onder bedrijven worden nagegaan waarom bedrijven in de verschillende sectoren BBL-leerlingen opleiden. Een beschrijving van de enquête is te vinden in Appendix $A$.

Korte-termijn belangen

Als een bedrijf met name korte-termijn belangen heeft bij het opleiden van een BBLleerling moeten de kosten van de opleiding in voldoende mate worden gecompenseerd door diens deelname in het productieproces. In deze paragraaf kijken we daarom eerst in welke mate een BBL-leerling kan worden ingezet in het productieproces en vervolgens of dit voldoende is om de kosten van de opleiding te compenseren.

Tabel 2.1

Percentage van de bedrijven dat zegt dat BBL-leerlingen een belangrijke rol in de bedrijfsvoering spelen

$\%$

$\begin{array}{llr}\text { Branche } & \text { Industrie } & 66 \\ & \text { Garage } & 76 \\ & \text { Landbouw } & - \\ & \text { Bouw } & 58 \\ & \text { Horeca } & 79 \\ & \text { Zakelijke dienstverlening } & 32 \\ & \text { Groot-, detailhandel } & 67 \\ & \text { Non-profit } & 69 \\ \text { Grootteklasse } & 1-9 \text { werknemers } & 58 \\ & 10-99 \text { werknemers } & 74 \\ \text { Alle bedrijven } & 100 \text { of meer werknemers } & 74 \\ & & 64\end{array}$

De rol van leerlingen in de bedrijfsvoering is voor bijna tweederde van de bedrijven een belangrijke overweging om BBL-leerlingen aan te nemen, zoals tabel 2.1 laat zien. Het belang van dit motief verschilt echter wel aanzienlijk tussen verschillende bedrijfssectoren. Dat geldt met name voor de zakelijke dienstverlening. In de zakelijke dienstverlening geeft slechts $32 \%$ van de bedrijven aan dat deze reden belangrijk is. Bedrijven uit de horeca en de garagesector geven juist veel vaker dan gemiddeld aan dat BBL-leerlingen een belangrijke rol in de bedrijfsvoering spelen. Opmerkelijk is dat middelgrote en grote bedrijven vaker dan kleine bedrijven aangegeven dat BBL-leerlingen een belangrijke rol hebben in de bedrijfsvoering. Dit spoort niet met de gedachte dat kleine bedrijven veel minder speciale opleidingsfaciliteiten hebben en leerlingen daar dus eerder in het productieproces mee zullen draaien.

Vervolgens kijken we wat de rol van BBL-leerlingen in de bedrijfsvoering feitelijk inhoudt. Bedrijven kunnen leerlingen op verschillende manieren inzetten. Ze kunnen 
leerlingen eenvoudige en ondersteunende taken geven of juist op dezelfde manier inzetten als andere medewerkers. Een en ander zal sterk afhankelijk zijn van de tijd dat de BBL-leerling al bij het leerbedrijf in dienst is. Een leerling die al enige tijd rondloopt zal andere werkzaamheden verrichten dan iemand die net begint. Ook is het mogelijk dat de werkzaamheden die een leerling uitvoert specifiek op de opleiding zijn gericht om een zo groot mogelijk leereffect te bereiken. Dat zal dan vaak ten koste gaan van het productiviteitseffect. Tabel 2.2 geeft voor verschillende werkzaamheden het percentage van de leerbedrijven dat zegt dat BBL-leerlingen deze vervullen. Het gaat hierbij om de werkzaamheden van een BBL-leerling die al enige tijd bij het bedrijf in dienst is. De verschillende categorieën sluiten elkaar niet uit, werkgevers konden meerdere antwoorden geven. Meer dan de helft van de bedrijven zegt dat BBL-leerlingen in wezen hetzelfde soort werk doen als andere medewerkers. Heel opvallend is dat bedrijven uit de zakelijke dienstverlening dit nog veel vaker dan gemiddeld zeggen. Bedrijven uit deze sector geven immers juist gemiddeld minder vaak aan dat BBL-leerlingen een belangrijke rol in de bedrijfsvoering spelen.

Tabel 2.2

Werkzaamheden van BBL-leerlingen

\begin{tabular}{|c|c|c|c|c|c|}
\hline & & $\begin{array}{l}\text { Eelfde soort } \\
\text { verk als andere } \\
\text { nedewerkers } \\
\%\end{array}$ & $\begin{array}{l}\text { Eenvoudiger } \\
\text { assisterend } \\
\text { werk } \\
\%\end{array}$ & $\begin{array}{l}\text { Taken om } \\
\text { veel van } \\
\text { te leren } \\
\%\end{array}$ & $\begin{array}{l}\text { Taken waar } \\
\text { ze goed in } \\
\text { zijn } \\
\quad \%\end{array}$ \\
\hline \multirow[t]{5}{*}{ Branche } & \multirow{5}{*}{$\begin{array}{l}\text { Industrie } \\
\text { Garage } \\
\text { Landbouw } \\
\text { Bouw } \\
\text { Horeca } \\
\text { Zakelijke } \\
\text { dienstverlening } \\
\text { Groot-, detail- } \\
\text { handel } \\
\text { Non-profit }\end{array}$} & $\begin{array}{l}54 \\
63\end{array}$ & $\begin{array}{l}49 \\
28\end{array}$ & $\begin{array}{l}38 \\
40\end{array}$ & $\begin{array}{l}23 \\
11\end{array}$ \\
\hline & & - & - & & \\
\hline & & $\begin{array}{l}51 \\
68\end{array}$ & $\begin{array}{l}41 \\
18\end{array}$ & $\begin{array}{l}49 \\
49\end{array}$ & $\begin{array}{l}19 \\
10\end{array}$ \\
\hline & & 72 & 8 & 69 & 7 \\
\hline & & $\begin{array}{l}45 \\
68\end{array}$ & $\begin{array}{l}20 \\
20\end{array}$ & $\begin{array}{l}37 \\
45\end{array}$ & $\begin{array}{r}33 \\
7\end{array}$ \\
\hline \multirow[t]{2}{*}{ Grootteklasse } & \multirow{2}{*}{$\begin{array}{l}1-9 \text { werknemers } \\
10-99 \text { werknemers } \\
100 \text { of meer werk- } \\
\text { nemers }\end{array}$} & $\begin{array}{l}55 \\
58\end{array}$ & $\begin{array}{l}26 \\
29\end{array}$ & $\begin{array}{l}49 \\
39\end{array}$ & $\begin{array}{l}22 \\
19\end{array}$ \\
\hline & & 61 & 20 & 40 & 8 \\
\hline \multicolumn{2}{|l|}{ Alle bedrijven } & 56 & 26 & 46 & 20 \\
\hline
\end{tabular}

Eenvoudiger en assisterend werk wordt door slechts een kwart van de bedrijven genoemd. Alleen in de industrie en de bouw doen BBL-leerlingen relatief vaak eenvoudig en assisterend werk. In de zakelijke dienstverlening doen BBL-leerlingen slechts heel zelden assisterend werk. Hoewel BBL-leerlingen vaak dezelfde werkzaamheden uitvoeren als andere medewerkers betreft dit toch ook vaak werkzaamheden waar ze veel van kunnen leren.

Bijna de helft van de bedrijven zegt dat BBL-leerlingen taken krijgen waar ze zoveel mogelijk van kunnen leren, voor de zakelijke dienstverlening is dat percentage zelfs 
bijna $70 \%$. Ten slotte houden bedrijven weinig rekening met de vaardigheden die leerlingen al hebben, ze worden meestal niet speciaal op taken gezet waar ze goed in zijn. Veel BBL-leerlingen doen weliswaar het zelfde soort werk als andere werknemers, maar dit wil niet zeggen dat ze ook even productief zijn als andere werknemers. Vaak moeten ze het werk al doende leren, ze zullen dus minder snel werken en meer fouten maken. Met name als het werk tevens zo is ingericht dat ze er zoveel mogelijk van kunnen leren zal, zoals gezegd, de productiviteit van BBLleerlingen een stuk lager liggen. Tabel 2.3 laat zien dat volgens werkgevers de productiviteit van een BBL-leerling ongeveer $60 \%$ is van de productiviteit van een gediplomeerde werknemer. Er zijn hierin weinig verschillen tussen bedrijfssectoren. Alleen de horeca en de zakelijke dienstverlening springen er wat dit betreft uit. Bij de eerstgenoemde ligt de gemiddelde productiviteit wat hoger dan gemiddeld, bij de laatste beduidend lager dan gemiddeld. Dit zijn overigens ook precies de bedrijfssectoren waar bedrijven respectievelijk vaker en minder vaak dan gemiddeld aangeven dat BBL-leerlingen een belangrijke rol in de bedrijfsvoering vervullen. In de zakelijke dienstverlening worden BBL-leerlingen weliswaar ingezet op hetzelfde werk als andere medewerkers maar wel op zo'n wijze dat ze daar zo veel mogelijk van leren, wat leidt tot een erg lage productiviteit van leerlingen. Dit is mogelijk omdat $\mathrm{BBL}-$ leerlingen geen belangrijke rol in de bedrijfsvoering vervullen.

Naast de directe inzet van BBL-leerlingen in het productieproces kunnen BBLleerlingen ook een positieve inbreng hebben doordat ze nieuwe kennis in huis brengen. Leerlingen leren op school wellicht nieuwe technieken waar het bedrijf anders niet zo snel mee in aanraking komt. Ruim $69 \%$ van de bedrijven zegt inderdaad dat dit een belangrijke reden is om BBL-leerlingen in dienst te hebben. Opnieuw geeft de zakelijke dienstverlening een afwijkend beeld te zien. Hier zegt maar $30 \%$ van de bedrijven dat dit een belangrijke reden is. Ook onder bouwbedrijven en garagebedrijven is dit percentage aanzienlijk lager dan gemiddeld. Bedrijven in de handel en de horeca geven juist relatief vaak aan dat het feit dat leerlingen nieuwe kennis binnenbrengen een belangrijke reden is om ze in dienst te hebben. Ook op dit punt laten kleine bedrijven een ander beeld zien dan middelgrote of grote bedrijven. Kleine bedrijven zeggen minder vaak dat leerlingen nieuwe kennis in huis brengen.

Tot nu toe hebben we gekeken naar de baten van BBL-leerlingen tijdens de leerperiode. We zullen nu ingaan op de kosten. De grootste kostenpost wordt gevormd door de loonkosten. Deze hoge loonkosten worden soms gedeeltelijk gecompenseerd door de fiscale aftrek en andere subsidies. Daarnaast moet een leerling begeleid worden door ervaren personeel. Sommige bedrijven hebben hiervoor zelfs speciale opleiders in dienst. Ten slotte zijn er nog kosten van materialen, leermiddelen etc. 
Tabel 2.3

Schatting van de gemiddelde productiviteit van een BBL-leerling t.o.v. een gediplomeerde, ingewerkte werknemer per bedrijf

\begin{tabular}{llcc}
\hline & & Gemiddelde & $\begin{array}{c}\text { Standaard } \\
\text { deviatie }\end{array}$ \\
\hline Branche & Industrie & 59 & 22 \\
& Garage & 60 & 15 \\
& Landbouw & - & - \\
& Bouw & 60 & 17 \\
& Horeca & 71 & 17 \\
& Zakelijke dienstverlening & 44 & 18 \\
Grootteklasse & Groot-, detailhandel & 61 & 13 \\
& Non-profit & 66 & 19 \\
& 1-9 werknemers & 60 & 18 \\
& 10-99 werknemers & 60 & 19 \\
& 100 of meer werknemers & 65 & 19 \\
\hline
\end{tabular}

Zoals gezegd vormen de loonkosten vaak een grote kostenpost. Veel leerlingen hebben naast hun leercontract ook een arbeidscontract en ontvangen loon. Er zijn echter ook leerlingen die alleen een leercontract hebben. Deze leerlingen ontvangen meestal alleen een (beperkte) onkosten- of stagevergoeding. De kosten van leerlingen zullen in sectoren waar leerlingen meestal geen arbeidscontract hebben gemiddeld beduidend lager zijn dan in sectoren waar leerlingen wel een arbeidscontract hebben. Tabel 2.5 geeft het percentage leerbedrijven dat aangeeft dat BBLleerlingen meestal alleen een leercontract hebben. Gemiddeld heeft in $30 \%$ van de bedrijven een leerling alleen een leercontract. In de zakelijke dienstverlening is dit percentage veel hoger, namelijk $65 \%$. Dus tegenover de lage opbrengst van leerlingen in deze sector staan ook lagere kosten doordat leerlingen vaak geen loon ontvangen. Ook in de non-profit sector is het percentage met alleen een leercontract hoog, namelijk 50\%. In de garagesector en de handel zijn er juist relatief weinig bedrijven waar BBL-leerlingen alleen een leercontract krijgen. Tabel $2.5 \mathrm{geeft}$ ook het percentage bedrijven dat BBL-leerlingen in dienst heeft die een contract hebben via een speciale sectororganisatie of GOA (gemeenschappelijke opleidingsactiviteiten). Hier liggen de zaken vrij ingewikkeld. Door sommige sectororganisaties wordt aan bedrijven waar BBL-leerlingen worden gedetacheerd detacheringskosten in rekening gebracht, door andere weer niet.

Een andere aanzienlijke kostenpost is de begeleiding van de BBL-leerling door ervaren collega's of door speciale opleiders die het bedrijf in dienst heeft. Gemiddeld kost een BBL-leerling 14 uur begeleidingstijd per week. Dit is uiteraard een erg hoog cijfer. Onduidelijk is echter in welke mate begeleidingstijd ten koste gaat van de eigen werkzaamheden van de begeleider. De echte kosten van begeleiding worden natuurlijk alleen gevormd door de productiviteit van de begeleiders die verloren gaat. Als een ervaren kracht, terwijl hij zelf aan het werk is, tips en instructies aan een leerling geeft, zal zijn eigen productiviteit nauwelijks worden aangetast. 
Het aantal uur begeleidingstijd varieert echter sterk tussen bedrijven zoals blijkt uit de standaarddeviatie. Deze sterke variatie kan er op duiden dat veel bedrijven veel moeite hebben om aan te geven hoeveel begeleidingstijd ze gemiddeld per week per leerling kwijt zijn. Sommige bedrijven overschatten de opleidingskosten andere onderschatten ze. Vooral als de begeleiding ad hoc is, tussen andere werkzaamheden door is het moeilijk om een schatting te geven. Als een bedrijf speciale opleiders in dienst heeft is dit makkelijker.

Tabel 2.4

Percentage van de bedrijven dat zegt dat BBL-leerlingen nieuwe kennis binnen het bedrijf brengen

$\%$

\begin{tabular}{llc}
\hline Branche & Industrie & 62 \\
& Garage & 49 \\
& Landbouw & - \\
& Bouw & 29 \\
& Horeca & 71 \\
& Zakelijke dienstverlening & 30 \\
Grootteklasse & Groot-, detailhandel & 86 \\
& Non-profit & 77 \\
Alle bedrijven & $1-9$ werknemers & 57 \\
& $10-99$ werknemers & 68 \\
& 100 of meer werknemers & 70 \\
\hline
\end{tabular}

Tabe/ 2.5

Het soort contract van BBL-leerlingen

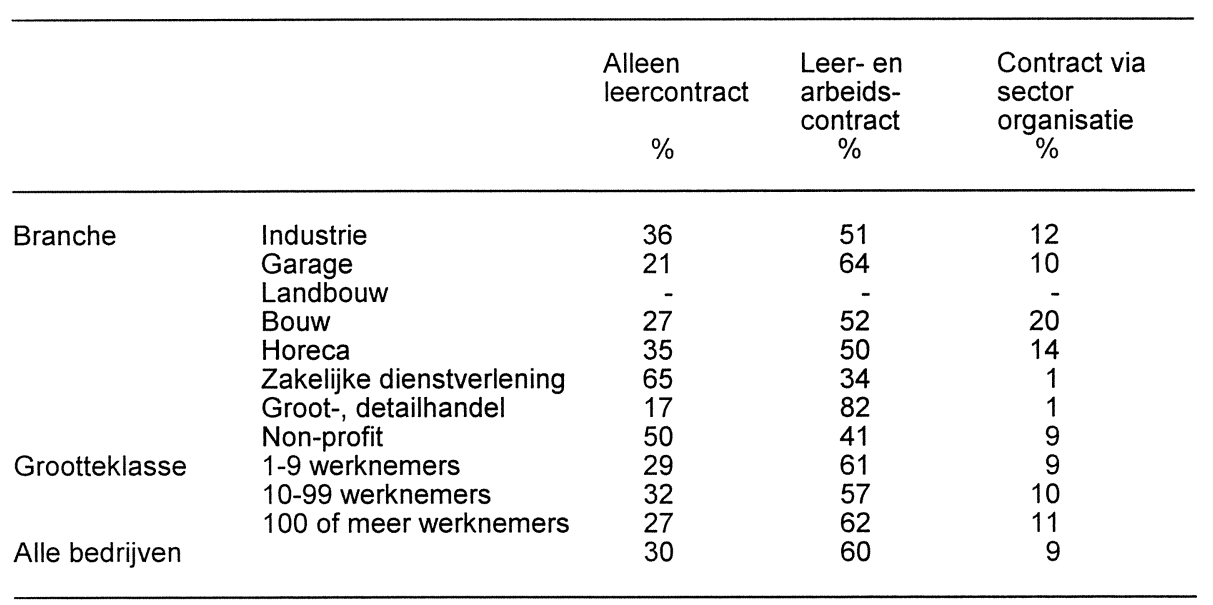

Een deel van de kosten wordt gecompenseerd door subsidies en de fiscale aftrekmogelijkheid. In totaal maakt $75 \%$ van de bedrijven gebruik van de fiscale aftrek of andere subsidies. In de zakelijke dienstverlening is dit percentage wat lager, maar in deze branche hebben BBL-leerlingen vaak geen arbeidscontract. In dat geval is het niet mogelijk om fiscale aftrek te krijgen. Er wordt immers geen loon betaald. 
Tabel 2.6

Schatting van het gemiddelde aantal uren begeleidingstijd per BBL-leerling per week

\begin{tabular}{llcc}
\hline & & Gemiddelde & $\begin{array}{l}\text { Standaard } \\
\text { deviatie }\end{array}$ \\
\hline Branche & Industrie & 13 & 20 \\
& Garage & 11 & 9 \\
& Landbouw & - & - \\
& Bouw & 18 & 12 \\
& Horeca & 16 & 15 \\
& Zakelijke dienstverlening & 15 & 19 \\
Grootteklasse & 15 & 14 \\
& Groot-, detailhandel & 10 & 11 \\
Alle bedrijven & 1-9 werknemers & 15 & 48 \\
& 10-99 werknemers & 12 & 15 \\
\hline & 100 of meer werknemers & 25 & \\
\hline
\end{tabular}

De fiscale aftrek is bedoeld om bedrijven te stimuleren meer leerlingen in dienst te nemen. Verwacht mag worden dat met name bedrijven waarvoor de BBL net niet rendabel is, gevoelig zijn voor een dergelijke maatregel. Dankzij de aftrekmogelijkheid wordt het dan wellicht net wel rendabel om leerlingen in dienst te nemen. Uit de enquêtegegevens blijkt dat bijna $40 \%$ van alle leerbedrijven zegt minder leerlingen te gaan aannemen als de subsidie weg zou vallen.

Tabel 2.7

Percentage bedrijven dat gebruik maakt van de fiscale faciliteit of andere subsidies

\begin{tabular}{lll}
\hline & & $\%$ \\
\hline \multirow{3}{*}{ Branche } & Industrie & 68 \\
& Garage & 84 \\
& Landbouw & $-\overline{7}$ \\
& Bouw & 77 \\
& Horeca & 57 \\
& Zakelijke dienstverlening & 75 \\
& Groot-, detailhandel & 70 \\
Grootteklasse & Non-profit & 80 \\
& 1-9 werknemers & 64 \\
Alle bedrijven & 10-99 werknemers & 74 \\
& 100 of meer werknemers & 75 \\
\hline
\end{tabular}

Hierbij moet echter wel met de mogelijkheid rekening worden gehouden dat bedrijven bij het beantwoorden van een dergelijke vraag neigen tot overdrijven omdat het in hun belang is dat de fiscale aftrek zal blijven bestaan. Van de bedrijven die al gebruik maken van de fiscale aftrek zeg verder bijna $60 \%$ meer leerlingen aan te gaan nemen als de fiscale aftrek verdubbelt. Hetzelfde geldt ook voor bedrijven die nu nog geen gebruik maken van de fiscale aftrek. Echter, ook deze resultaten moeten met de nodige voorzichtigheid worden geïnterpreteerd, omdat bedrijven er alle baat bij hebben het belang van de fiscale aftrek te overdrijven. 
Ten slotte is nog gevraagd of BBL-leerlingen zich tijdens de leerperiode terugverdienen. Uit tabel 2.8 blijkt dat tweederde van de bedrijven aangeeft dat leerlingen zich tijdens de leerperiode terugverdienen. Onder garagebedrijven, in de horeca en in de industrie is dit percentage nog veel hoger respectievelijk $87 \%, 77 \%$ en $73 \%$. Overigens geldt wel dat in de meeste garagebedrijven een leerling zich maar net terugverdient. In de industrie en horeca verdienen leerlingen zich ook vaak ruim terug. Het is nauwelijks verbazingwekkend dat de helft van de bedrijven in de zakelijke dienstverlening aangeeft dat leerlingen zich niet terugverdienen, gezien de lage productiviteit van leerlingen in deze sector. Bij kleine bedrijven vormen leerlingen vaker een netto kostenpost dan bij middelgrote en grote bedrijven.

Overigens is het percentage bedrijven dat zegt dat BBL-leerlingen geen netto kostenpost vormen opvallend hoog, zeker in vergelijking met ander onderzoek naar de kosten en baten van leerlingwezen voor bedrijven. Uit dergelijk onderzoek blijkt meestal dat leerlingen een hoge kostenpost vormen. Ook blijkt uit deze literatuur dat bedrijven zich daar vaak niet bewust van zijn (zie De Vries en Heere, 1993). Mogelijkerwijs onderschatten bedrijven de kosten van leerlingen. Echter, de beslissing om wel of geen BBL-leerlingen aan te nemen is vaak niet gebaseerd op een uitgebreide analyse van kosten en baten maar op een globale inschatting. De eigen inschatting is dus doorslaggevend. Daarnaast is het mogelijk dat bij een expliciete analyse bepaalde kosten of baten ten onrechte niet worden meegerekend.

Tabel 2.8

Percentage van de bedrijven dat zegt dat BBL-leerlingen zich terug verdienen

\begin{tabular}{llc}
\hline & & $\%$ \\
\hline \multirow{3}{*}{ Branche } & Industrie & 73 \\
& Garage & 87 \\
& Landbouw & - \\
& Bouw & 65 \\
& Horeca & 76 \\
& Zakelijke dienstverlening & 45 \\
Grootteklasse & Groot-, detailhandel & 59 \\
& Non-profit & 71 \\
Alle bedrijven & 1-9 werknemers & 59 \\
& $10-99$ werknemers & 78 \\
& 100 of meer werknemers & 68 \\
& & 66 \\
\hline
\end{tabular}

De meeste bedrijven hebben al tijdens de leerperiode baat bij BBL-leerlingen. Echter, voor eenderde van de bedrijven zijn leerlingen een netto kostenpost. Als deze bedrijven toch leerlingen in dienst hebben moeten er kennelijk lange-termijn-baten tegenover staan.

\section{Lange-termijn belangen}

Een eerste voorwaarde voor het bestaan van lange-termijn motieven is dat het voordeliger is om zelf mensen op te leiden dan op termijn gekwalificeerd personeel op de 
markt te werven. Voordelen zijn, zoals gezegd, onder andere de mogelijkheid om zo de beste werknemers te kunnen selecteren en de mogelijkheid om BBL-leerlingen bedrijfsspecifieke vaardigheden aan te leren. Een tweede vereiste is dan natuurlijk dat er een redelijke kans bestaat dat de leerling na afloop van de opleiding inderdaad enige tijd bij het leerbedrijf blijft.

Tabel 2.9 geeft het percentage bedrijven dat BBL-leerlingen opleidt om in de toekomst voldoende gekwalificeerd personeel in huis te hebben. Het blijkt dat dit voor bijna alle bedrijven (92\%) een belangrijke reden is. De verschillen tussen bedrijfssectoren zijn minimaal. Alleen in de horeca is het percentage lager dan gemiddeld, maar toch ook nog $87 \%$. Overigens is de horeca een van de sectoren waar de korte-termijn baten het grootst zijn doordat leerlingen een belangrijke rol in de bedrijfsvoering spelen. $\mathrm{Er}$ is enige invloed van bedrijfsomvang, grote bedrijven zeggen iets vaker leerlingen op te leiden vanwege een toekomstige behoefte dan kleine bedrijven, maar ook hier zijn de verschillen minimaal.

Tabel 2.9

Percentage van de bedrijven dat zegt dat BBL-leerlingen van belang zijn om in de toekomst voldoende gekwalificeerd personeel in huis te hebben

\begin{tabular}{lll}
\hline & & $\%$ \\
\hline \multirow{3}{*}{ Branche } & Industrie & 91 \\
& Garage & 82 \\
& Landbouw & - \\
& Bouw & 86 \\
& Horeca & 98 \\
& Zakelijke dienstverlening & 97 \\
& Groot-, detailhandel & 93 \\
Grootteklasse & Non-profit & 99 \\
& 1-9 werknemers & 92 \\
Alle bedrijven & 10-99 werknemers & 93 \\
& 100 of meer werknemers & 97 \\
& & 92 \\
\hline
\end{tabular}

Veel bedrijven zeggen BBL-leerlingen op te leiden met het oog op een toekomstige personeelsbehoefte. Het is nu de vraag of bedrijven leerlingen ook daadwerkelijk in dienst houden na afloop van de opleiding. Overigens heeft een aanzienlijk deel van de leerlingen al tijdens de opleiding een vaste aanstelling. Als een leerling al een vaste aanstelling heeft dan is het zeer waarschijnlijk dat het bedrijf de opleiding ook daadwerkelijk ziet als investering in het personeel, dus dat er sprake is van langetermijn-baten. Tabel 2.10 geeft het percentage bedrijven dat BBL-leerlingen in dienst heeft met een vaste aanstelling. Het arbeidscontract is dan niet beperkt tot de duur van de opleiding. Het blijkt dat maar liefst bij een kwart van de bedrijven sprake is van vaste contracten voor leerlingen. Een uitschieter vormen de garagebedrijven waar maar liefst bij $47 \%$ sprake is van een vaste aanstelling. Ook in de handel ligt het percentage ver boven gemiddeld. In de zakelijke dienstverlening hebben leerlingen slechts zelden een vaste aanstelling maar we zagen al eerder dat de meeste leerlingen daar sowieso geen arbeidscontract hebben. Verder blijkt dat leerlingen in kleine en middelgrote bedrijven vaker een vaste aanstelling hebben dan 
in grote bedrijven. Dit is niet verbazingwekkend, daar grote bedrijven meer mogelijkheden hebben om meer leerlingen op te leiden dan ze in de toekomst nodig hebben met het oog op mogelijke uitval. Bijvoorbeeld vanwege ongeschiktheid of het niet afmaken van de opleiding etc.

Tabel 2.10

Percentage van de bedrijven dat leerlingen heeft met een vaste aanstelling

\begin{tabular}{llc}
\hline & & $\%$ \\
\hline \multirow{2}{*}{ Branche } & Industrie & 18 \\
& Garage & 47 \\
& Landbouw & - \\
& Bouw & 16 \\
& Horeca & 20 \\
& Zakelijke dienstverlening & 5 \\
& Groot-, detailhandel & 38 \\
Grootteklasse & Non-profit & 19 \\
& 1-9 werknemers & 25 \\
Alle bedrijven & $10-99$ werknemers & 26 \\
& 100 of meer werknemers & 13 \\
& & 25 \\
\hline
\end{tabular}

Tabel 2.11

Kans dat het bedrijf een leerling zonder vaste aanstelling na de opleiding een vervolgaanstelling aanbiedt

\begin{tabular}{lll}
\hline & & $\%$ \\
\hline \multirow{3}{*}{ Branche } & Industrie & \\
& Garage & 84 \\
& Landbouw & 84 \\
& Bouw & - \\
& Horeca & 96 \\
& Zakelijke dienstverlening & 46 \\
& Groot-, detailhandel & 77 \\
Grootteklasse & Non-profit & 66 \\
& 1-9 werknemers & 72 \\
Alle bedrijven & 10-99 werknemers & 76 \\
& 100 of meer werknemers & 81 \\
& & 74 \\
\hline
\end{tabular}

De kans dat een bedrijf een BBL-leerling die nog geen vaste aanstelling heeft een vervolgcontract aanbiedt is $74 \%$, zoals tabel 2.11 laat zien. Bij bedrijven in de industrie, garagesector en de bouw is deze kans echter nog een stuk hoger. In de bouw hebben overigens erg weinig BBL-leerlingen al een vast contract tijdens de opleiding. Dit gemis aan zekerheid wordt dus gecompenseerd door de zeer hoge kans op een vervolgaanstelling. In de horeca is de gemiddelde kans lager dan $50 \%$. Dit is niet zo verbazingwekkend omdat deze sector minder vaak mensen opleidt vanwege een toekomstige behoefte aan gekwalificeerd personeel. 
Zoals verwacht hangt de kans dat iemand een vervolgaanstelling wordt aangeboden met name af van de kwaliteiten van de betreffende persoon en in iets mindere mate van de behoefte aan personeel op dat moment.

De behoefte aan geschoold personeel kan veelal van te voren worden ingeschat. De kwaliteiten van de betreffende werknemer kunnen niet worden voorzien, omdat de leerperiode juist benut wordt om zich een beeld van de leerling te vormen. Daarnaast zullen bedrijven echt goede werknemers ook willen houden als er op dat moment even wat minder werk is. Dit komt overeen met de eerder genoemde selectiehypothese. Bedrijven leiden BBL-leerlingen op omdat ze op die wijze de beste werknemers kunnen selecteren. Het is overigens opvallend dat de kwaliteiten van de leerlingen in de horeca en de non-profit sector een veel minder belangrijke rol spelen bij het aanbieden van een vervolgaanstelling.

Een andere reden om BBL-leerlingen op te leiden kan zijn dat het moeilijk is om personeel dat elders is opgeleid in te zetten. Bijvoorbeeld omdat men onvoldoende informatie heeft over de kwaliteit van de opleiding bij dat andere bedrijf of als bedrijfsspecifieke vaardigheden van groot belang zijn om in het eigen bedrijf te functioneren. In totaal zegt bijna een kwart van de bedrijven dat het moeilijk is om BBL-leerlingen in te zetten die elders zijn opgeleid. In de garagesector is dat bijna de helft en in de zakelijke dienstverlening ruim de helft van de bedrijven. In de hore$\mathrm{ca}$, de handel en non-profit organisaties is het juist makkelijk om leerlingen die elders zijn opgeleid in te zetten. Overigens weet ruim $10 \%$ van de bedrijven (en in de bouw 25\%) het antwoord op deze vraag niet. Mogelijk speelt hier toch dat ze onvoldoende inzicht hebben in de kwaliteit van de opleiding die elders is genoten.

Tabel 2.12

Percentage bedrijven dat zegt dat het al dan niet aanbieden van een vervolgaanstelling sterk afhangt van de personeelsbehoefte op dat moment of de kwaliteit van de leerling

\begin{tabular}{llcc}
\hline & & $\begin{array}{c}\text { Behoefte aan } \\
\text { personeel } \\
\%\end{array}$ & $\begin{array}{c}\text { Kwaliteit } \\
\text { leerling } \\
\%\end{array}$ \\
\hline Branche & Industrie & 44 & 76 \\
& Garage & 58 & 82 \\
& Landbouw & - & - \\
& Bouw & 39 & 87 \\
& Horeca & 42 & 61 \\
& Zakelijke dienstverlening & 63 & 94 \\
Grootteklasse & Groot-, detailhandel & 64 & 64 \\
& Non-profit & 65 & 84 \\
1-9 werknemers & 57 & 81 \\
& 10-99 werknemers & 49 & 76 \\
& 100 of meer werknemers & 52 & 83 \\
\hline
\end{tabular}

Voor de meeste BBL-leerlingen is het wel vrij makkelijk om buiten het leerbedrijf werk te vinden. Slechts $3 \%$ van de bedrijven meldt dat het voor zijn BBL-leerlingen moeilijk is om elders werk te vinden. Dit antwoord wordt mogelijk ook door de 
huidige arbeidskrapte beïnvloed. Het is misschien moeilijk voor andere bedrijven om leerlingen van dit bedrijf in te zetten maar de huidige arbeidsmarktkrapte maakt dat ze het toch gaan proberen zodat leerlingen elders toch snel werk vinden.

Tabel 2.13

Percentage bedrijven dat zegt dat hun BBL-leerlingen moeilijk elders werk kunnen vinden en/of dat het moeilijk is om werknemers in te zetten die elders zijn opgeleid

\begin{tabular}{|c|c|c|c|}
\hline & & $\begin{array}{l}\text { Moeilijk om elders } \\
\text { werk te vinden } \\
\quad \%\end{array}$ & $\begin{array}{l}\text { Moeilijk om elders } \\
\text { opgeleid personeel } \\
\text { in te zetten } \\
\%\end{array}$ \\
\hline \multirow[t]{7}{*}{ Branche } & $\begin{array}{l}\text { Industrie } \\
\text { Garage }\end{array}$ & $\begin{array}{l}36 \\
47\end{array}$ & $\begin{array}{l}22 \\
12\end{array}$ \\
\hline & Landbouw & - & - \\
\hline & Bouw & 25 & 22 \\
\hline & Horeca & 19 & 26 \\
\hline & Zakelijke dienstverlening & 54 & 14 \\
\hline & Groot-, detailhandel & 13 & 19 \\
\hline & Non-profit & 14 & 20 \\
\hline \multirow[t]{3}{*}{ Grootteklasse } & $1-9$ werknemers & 23 & 21 \\
\hline & 10-99 werknemers & 28 & 18 \\
\hline & 100 of meer werknemers & 24 & 27 \\
\hline Alle bedrijven & & 24 & 20 \\
\hline
\end{tabular}

Tabel 2.14

Kans dat een BBL-leerling bij het leerbedrijf wil blijven

\begin{tabular}{llc}
\hline & & $\%$ \\
\hline \multirow{2}{*}{ Branche } & Industrie & 79 \\
& Garage & 74 \\
& Landbouw & - \\
& Bouw & 82 \\
& Horeca & 57 \\
& Zakelijke dienstverlening & 76 \\
& Groot-, detailhandel & 67 \\
Grootteklasse & Non-profit & 77 \\
& 1-9 werknemers & 68 \\
Alle bedrijven & 10-99 werknemers & 78 \\
& 100 of meer werknemers & 83 \\
& & 72 \\
\hline
\end{tabular}

De gemiddelde kans dat een BBL-leerling die een vervolgaanstelling aangeboden krijgt ook blijft is ruim $70 \%$. In de bouw en industrie ligt deze gemiddelde kans hoger namelijk op respectievelijk $82 \%$ en $79 \%$. In de horeca is deze kans juist weer een stuk lager. In de horeca kunnen leerlingen ook heel eenvoudig elders werk vinden. De kans loopt ook duidelijk op met de bedrijfsgrootte. Voor kleine bedrijven is de kans minder dan $70 \%$ en voor grote bedrijven boven de $80 \%$.

Ten slotte kan een bedrijf ook leerlingen in dienst hebben zonder dat het daar zelf direct baat bij heeft. In veel bedrijfssectoren zijn er bijvoorbeeld afspraken gemaakt over het aantal leerlingen dat in de sector moet worden opgeleid. Door sectoraal 
afspraken te maken over het opleidingsbeleid kan 'free rider' gedrag van bedrijven worden voorkomen. Alle bedrijven in een sector hebben er immers belang bij dat er voldoende gekwalificeerd personeel beschikbaar is, maar een individueel bedrijf heeft er geen belang bij om werknemers op te leiden als andere bedrijven in de sector dat al doen. Tabel 2.15 laat zien dat afspraken in de sector inderdaad voor veel bedrijven een belangrijke reden is om leerlingen in dienst te nemen. Alleen in de zakelijke dienstverlening zijn sectorafspraken niet van belang. Daarnaast speelt ook de wil om bij te dragen aan scholing een zeer belangrijke rol voor de meeste bedrijven, ook indien er geen specifieke afspraken zijn, zoals in de zakelijke dienstverlening.

Tabel 2.15

Overige redenen om BBL-leerlingen te hebben

\begin{tabular}{llcc}
\hline & & $\begin{array}{c}\text { Wil bijdragen } \\
\text { aan scholing } \\
\%\end{array}$ & $\begin{array}{c}\text { Afspraken } \\
\text { binnen sector } \\
\%\end{array}$ \\
\hline Branche & Industrie & 91 & 57 \\
& Garage & 82 & 54 \\
& Landbouw & - & 53 \\
& Bouw & 86 & 74 \\
& Horeca & 98 & 20 \\
& Zakelijke dienstverlening & 97 & 79 \\
Grootteklasse & Groot-, detailhandel & 93 & 60 \\
& Non-profit & 99 & 70 \\
Alle bedrijven & 1-9 werknemers & 92 & 68 \\
& 10-99 werknemers & 93 & 63 \\
\hline
\end{tabular}

\subsection{Bedrijven zonder leerlingen}

Niet alle bedrijven die baat zouden kunnen hebben bij de beroepsbegeleidende leerweg hebben ook BBL-leerlingen in dienst. Om een goed beeld te krijgen van de factoren die van belang zijn voor de vraag naar leerlingen is het van belang om ook naar de overwegingen van niet-leerbedrijven te kijken. Zijn er voor deze bedrijven redenen om toch te overwegen leerlingen in dienst te nemen, en zo ja door welke belemmeringen doen zij dit toch niet?

De meeste niet-leerbedrijven noemen de toekomstige behoefte aan gekwalificeerd personeel een belangrijke reden om eventueel toch BBL-leerlingen in dienst te nemen. De verschillen tussen bedrijfssectoren zijn op dit punt niet zo groot, zoals blijkt uit tabel 2.16. In de landbouw wordt deze reden wat minder belangrijk gevonden dan in andere sectoren, maar zelfs hier noemt nog ruim $70 \%$ deze reden belangrijk.

Daarnaast wordt ook de rol van de BBL-leerling in de bedrijfsvoering, de inbreng van nieuwe kennis en de wil om bij te dragen aan scholing in de sector door veel nietleerbedrijven belangrijk gevonden. Geconcludeerd kan worden dat ook veel bedrij- 
ven die nu geen BBL-leerlingen in dienst hebben hier toch baat bij kunnen hebben. Blijkbaar worden momenteel deze baten echter teniet gedaan door de hoge kosten of zijn er andere belemmeringen die de bedrijven ervan weerhouden leerlingen in dienst te nemen.

Tabe/ 2.16

Redenen om eventueel toch BBL-leerlingen in dienst te nemen

\begin{tabular}{|c|c|c|c|c|c|}
\hline & & $\begin{array}{l}\text { Rol in de } \\
\text { bedrijfs- } \\
\text { voering } \\
\quad \%\end{array}$ & $\begin{array}{l}\text { Inbreng } \\
\text { nieuwe } \\
\text { kennis } \\
\%\end{array}$ & $\begin{array}{c}\text { Toekomstige } \\
\text { behoefte aan } \\
\text { gekwalificeerd } \\
\text { personeel } \\
\%\end{array}$ & $\begin{array}{c}\text { Wil bijdragen } \\
\text { aan scholing } \\
\%\end{array}$ \\
\hline $\begin{array}{l}\text { Grootteklasse } \\
\text { Alle bedrijven }\end{array}$ & $\begin{array}{l}\text { Industrie } \\
\text { Garage } \\
\text { Landbouw } \\
\text { Bouw } \\
\text { Horeca } \\
\text { Zakelijke dienstverlening } \\
\text { Groot-, detailhandel } \\
\text { Non-profit } \\
1-9 \text { werknemers } \\
10-99 \text { werknemers } \\
100 \text { of meer werknemers }\end{array}$ & $\begin{array}{r}49 \\
56 \\
57 \\
58 \\
58 \\
5 \quad 61 \\
90 \\
70 \\
66 \\
63 \\
58 \\
5 \quad 60 \\
63\end{array}$ & $\begin{array}{l}55 \\
46 \\
65 \\
36 \\
75 \\
70 \\
78 \\
72 \\
70 \\
60 \\
68 \\
69\end{array}$ & $\begin{array}{l}81 \\
85 \\
72 \\
94 \\
83 \\
90 \\
82 \\
84 \\
84 \\
89 \\
89 \\
84\end{array}$ & $\begin{array}{l}57 \\
58 \\
65 \\
72 \\
65 \\
64 \\
66 \\
63 \\
64 \\
73 \\
81 \\
65\end{array}$ \\
\hline
\end{tabular}

Tabel 2.17

Redenen om geen BBL-leerlingen in dienst te hebben

\begin{tabular}{|c|c|c|c|c|c|c|}
\hline & & $\begin{array}{l}\text { Te veel } \\
\text { admini- } \\
\text { stratie } \\
\\
\quad \%\end{array}$ & $\begin{array}{l}\text { Te hoge } \\
\text { kosten }\end{array}$ & $\begin{array}{l}\text { Te grote } \\
\text { kans dat } \\
\text { leerling na } \\
\text { opleiding } \\
\text { vertrekt } \\
\%\end{array}$ & $\begin{array}{l}\text { Te veel } \\
\text { belemme- } \\
\text { ringen om } \\
\text { erkend te } \\
\text { worden } \\
\quad \%\end{array}$ & $\begin{array}{l}\text { Moeilijk } \\
\text { om } \\
\text { leerling- } \\
\text { en te } \\
\text { vinden } \\
\quad \%\end{array}$ \\
\hline \multirow[t]{3}{*}{ Branche } & \multirow{5}{*}{$\begin{array}{l}\text { Industrie } \\
\text { Garage } \\
\text { Landbouw } \\
\text { Bouw } \\
\text { Horeca } \\
\text { Zakelijke } \\
\text { dienstverlening } \\
\text { Groot-, detail- } \\
\text { handel } \\
\text { Non-profit } \\
1-9 \text { werknemers } \\
10-99 \text { werknemers } \\
100 \text { of meer werk- } \\
\text { nemers }\end{array}$} & $\begin{array}{l}22 \\
42 \\
46 \\
38 \\
24\end{array}$ & $\begin{array}{l}47 \\
35 \\
38 \\
45 \\
40\end{array}$ & $\begin{array}{l}55 \\
68 \\
40 \\
75 \\
49\end{array}$ & $\begin{array}{l}42 \\
25 \\
35 \\
37 \\
56\end{array}$ & $\begin{array}{l}60 \\
69 \\
51 \\
77 \\
66\end{array}$ \\
\hline & & 26 & 36 & 48 & 49 & 55 \\
\hline & & $\begin{array}{l}18 \\
20\end{array}$ & $\begin{array}{l}38 \\
36\end{array}$ & $\begin{array}{l}43 \\
32\end{array}$ & $\begin{array}{l}28 \\
50\end{array}$ & $\begin{array}{l}56 \\
33\end{array}$ \\
\hline Grootteklasse & & $\begin{array}{l}26 \\
22\end{array}$ & $\begin{array}{l}39 \\
35\end{array}$ & $\begin{array}{l}46 \\
54\end{array}$ & $\begin{array}{l}40 \\
37\end{array}$ & $\begin{array}{l}56 \\
56\end{array}$ \\
\hline Alle bedrijven & & $\begin{array}{l}19 \\
25\end{array}$ & $\begin{array}{l}38 \\
39\end{array}$ & $\begin{array}{l}50 \\
47\end{array}$ & $\begin{array}{l}11 \\
40\end{array}$ & $\begin{array}{l}65 \\
56\end{array}$ \\
\hline
\end{tabular}

Tabel 2.17 geeft de belangrijkste redenen waarom niet-leerbedrijven geen BBLleerlingen in dienst hebben. Als belangrijkste argument wordt genoemd dat het moeilijk is om leerlingen te vinden en vervolgens dat de kans dat de BBL-leerling na afloop vertrekt te groot is. Meer dan de helft van de bedrijven zonder leerlingen zou 
dus best BBL-leerlingen in dienst willen nemen maar kan ze gewoon niet vinden. In de bouw is het tekort aan leerlingen het grootst, in deze sector zegt meer dan driekwart van de bedrijven dat dit een belangrijke reden is om geen leerlingen in dienst hebben. Uit tabel 2.16 bleek al dat de toekomstige behoefte aan gekwalificeerd personeel voor de meeste niet-leerbedrijven toch een reden zou kunnen zijn $B B L-l e e r l i n g e n$ in dienst te nemen. Deze reden zal echter alleen doorslaggevend zijn als er ook een redelijke kans is dat leerlingen na afloop van de opleiding ook bij het leerbedrijf blijven. De meeste niet-leerbedrijven schatten deze kans echter erg laag in, bijna $50 \%$ van de bedrijven geeft aan dat dit punt een belangrijke reden is om geen leerlingen aan te nemen. Andere redenen die van belang zijn, zijn de hoge opleidingskosten en belemmeringen om als leerbedrijf erkend te worden. Dit laatste punt speelt overigens vooral bij het midden- en kleinbedrijf. De hoeveelheid administratie waarmee het in dienst nemen en opleiden van leerlingen gepaard gaat is voor veel minder bedrijven een reden om geen leerlingen in dienst te nemen.

Tabel 2.18

Percentage van de niet -leerbedrijven dat zegt dat BBL-leerlingen zich terugverdienen

\begin{tabular}{lll}
\hline & & $\%$ \\
\hline \multirow{3}{*}{ Branche } & Industrie & 57 \\
& Garage & 26 \\
& Landbouw & 58 \\
& Bouw & 49 \\
& Horeca & 67 \\
& Zakelijke dienstverlening & 47 \\
& Groot-, detailhandel & 76 \\
Grootteklasse & Non-profit & 50 \\
& 1-9 werknemers & 61 \\
Alle bedrijven & $10-99$ werknemers & 55 \\
& 100 of meer werknemers & 38 \\
& & 60 \\
\hline
\end{tabular}

Dat de hoge kosten voor het merendeel van de niet-leerbedrijven niet de voornaamste reden is om geen leerlingen op te leiden, blijkt ook uit tabel 2.18. De tabel laat zien dat $60 \%$ van alle niet-leerbedrijven denkt dat BBL-leerlingen zich zelf tijdens de aanstelling terug zullen verdienen. Eerder bleek al dat van de leerbedrijven $66 \%$ zegt dat leerlingen zich terugverdienen. Overigens zijn er op bedrijfssectorniveau wel grote verschillen tussen bedrijven met en zonder BBL-leerlingen. Dat geldt in sterke mate voor de garagesector. Terwijl in deze sector $87 \%$ van de leerbedrijven aangeeft dat leerlingen zich zullen terugverdienen, is dit percentage onder niet-leerbedrijven slechts $26 \%$. Opvallend genoeg geven de niet-leerbedrijven in de garagesector niet vaker dan in andere sectoren aan dat de hoge opleidingskosten een reden zijn om geen leerlingen op te leiden. Waarschijnlijk zijn deze bedrijven dus wel bereid om de hoge kosten te dragen, als ze er zeker van zouden zijn dat de BBL-leerling na afloop enige tijd in het leerbedrijf zou blijven werken. De meeste niet-leerbedrijven in de garagesector schatten deze kans erg laag in. Het zelfde argument geldt voor bedrijven in de bouw en in de industrie. 
Geconcludeerd kan worden dat veel bedrijven die nu nog geen BBL-leerlingen in dienst hebben dit wel overwegen. De belangrijkste belemmeringen zijn momenteel echter niet de hoge opleidingskosten maar een tekort aan leerlingen. Daarnaast vinden veel bedrijven het risico dat een BBL-leerling na afloop van de opleiding vertrekt te groot. De belangrijkste reden om BBL-leerlingen op te leiden, namelijk de toekomstige personeelsvoorziening, vervalt hierdoor.

\subsection{Het effect van werkgelegenheidsgroei op de vraag naar BBL- en BOL-leer- lingen}

In de vorige paragrafen bleek al dat veel bedrijven de BBL zien als een middel om in de toekomstige personeelsbehoefte te voorzien. Daarnaast speelt ook de directe inzet van de leerling in het bedrijfsproces een rol. In deze paragraaf zal worden bekeken in hoeverre bedrijven hun opleidingsbeleid aanpassen bij verwachte groei van het bedrijf. Hierbij spelen meerdere factoren een rol. Ten eerste is van belang of de groei tijdelijk of structureel is. Als er tijdelijk extra behoefte is aan personeel, dan loont het alleen om leerlingen in dienst te nemen als ze ook direct in het productieproces kunnen worden ingezet. Als er structureel behoefte is aan extra personeel dan kan het bedrijf hierin voorzien door zelf leerlingen op te leiden. Een belangrijke voorwaarde is dan natuurlijk wel dat deze leerlingen na afloop van de opleiding ook enige tijd bij het leerbedrijf blijven werken. Daarnaast is van belang in welke mate een bedrijf het aantal leerlingen kan laten variëren. Meer leerlingen betekent immers ook dat de opleidingscapaciteit van het bedrijf moet worden vergroot. Er moeten dan bijvoorbeeld meer mensen worden ingezet voor de begeleiding. Bij een grote behoefte aan extra mankracht kan het moeilijk zijn om hier personeel voor vrij te maken. Verwachte groei van het bedrijf hoeft dus niet direct tot een toename van het aantal leerlingen te leiden. Het kan ook zijn dat een bedrijf pas meer leerlingen gaat aannemen als de groei reeds is gerealiseerd. Het bedrijf hanteert dan bijvoorbeeld een vaste vuistregel voor het aantal leerlingen ten opzichte van het totale personeelsbestand.

In de enquête onder bedrijven is gevraagd welke mensen men zou willen aannemen als er tijdelijk dan wel structureel behoefte is aan extra personeel. Bij een tijdelijke behoefte gaat het dan om maximaal twee jaar. Dit is de duur van de meeste BBL-en BOL-opleidingen. Verwacht mag worden dat bedrijven die leerlingen in dienst nemen vanwege lange-termijn overwegingen alleen leerlingen aannemen bij een structurele behoefte aan extra personeel. Bedrijven die zeggen dat ze alleen bij een tijdelijke behoefte leerlingen willen aan nemen hebben duidelijk korte-termijn overwegingen bij het opleiden van leerlingen. Ten slotte kunnen bedrijven die zowel bij een tijdelijke als bij een structurele extra personeelsbehoefte leerlingen aannemen zowel korte- als lange-termijn motieven hebben.

Tabel 2.19 geeft het percentage bedrijven dat bij een tijdelijke of structurele groei BBL-leerlingen zou willen aannemen. De meeste bedrijven die BBL-leerlingen zouden willen aannemen bij groei, doen dit zowel bij een tijdelijke als structurele behoefte aan extra personeel. Er zijn hierin echter grote verschillen tussen de 
sectoren. In de bouw neemt men vrijwel alleen bij structurele groei BBL-leerlingen aan terwijl in de handel juist vaker alleen bij een tijdelijke personeelsbehoefte BBLleerlingen worden aangenomen. Opvallend is overigens dat bijna driekwart van de bedrijven helemaal niet reageert op verwachte groei. Dat geldt zowel voor bedrijven die al BBL-leerlingen in dienst hebben als bedrijven die (nog) geen leerlingen hebben.

Tabel 2.19

Percentage bedrijven dat bij tijdelijke of structurele groei BBL-leerlingen aanneemt

\begin{tabular}{llrrr}
\hline & & $\begin{array}{c}\text { Tijdelijk } \\
\%\end{array}$ & $\begin{array}{c}\text { Structureel } \\
\%\end{array}$ & $\begin{array}{c}\text { Beide } \\
\%\end{array}$ \\
\hline \multirow{2}{*}{ Branche } & Industrie & 7 & 14 & 12 \\
& Garage & 11 & 8 & 16 \\
& Landbouw & 11 & 6 & 14 \\
& Bouw & 2 & 10 & 1 \\
& Horeca & 3 & 5 & 28 \\
& Zakelijke dienstverlening & 1 & 2 & 15 \\
& Groot-, detailhandel & 14 & 1 & 12 \\
Grootteklasse & Non-profit & 7 & 6 & 14 \\
& 1-9 personen & 7 & 4 & 14 \\
& 10-99 personen & 9 & 6 & 14 \\
& 100 of meer & 9 & 5 & 14 \\
\hline
\end{tabular}

Tabel 2.20

Percentage bedrijven dat bij tijdelijke of structurele groei BOL-leerlingen aanneemt

\begin{tabular}{llccc}
\hline & & $\begin{array}{c}\text { Tijdelijk } \\
\%\end{array}$ & $\begin{array}{c}\text { Structureel } \\
\%\end{array}$ & $\begin{array}{c}\text { Beide } \\
\%\end{array}$ \\
\hline \multirow{3}{*}{ Branche } & & & 12 & 13 \\
& Industrie & 6 & 2 & 5 \\
& Garage & 8 & 6 & 13 \\
& Landbouw & 13 & 2 & 8 \\
& Bouw & 5 & 1 & 14 \\
& Horeca & 9 & 24 & 13 \\
& Zakelijke dienstverlening & 4 & 8 & 13 \\
& Groot-, detailhandel & 14 & 5 & 16 \\
\multirow{5}{*}{ Alle bedrijven } & Non-profit & 11 & 2 & 14 \\
& 1-9 personen & 10 & 6 & 15 \\
& 10-99 personen & 9 & 5 & \\
& 100 of meer & 8 & 2 & 11 \\
& & 10 & 6 & \\
\hline
\end{tabular}

Tabel 2.20 geeft ten slotte het percentage bedrijven dat bij tijdelijke of structurele behoefte aan extra personeel BOL-leerlingen aan wil nemen. In de meeste bedrijfssectoren wil men bij extra personeelsbehoefte even vaak BOL-leerlingen als BBL-leerlingen inzetten. Uitzonderingen daarin zijn echter de garagesector, de bouw en de zakelijke dienstverlening. In de twee eerstgenoemde sectoren wil men vaker BBL- dan BOL-leerlingen aannemen terwijl in de laatsgenoemde sector BOLleerlingen vaak de voorkeur hebben. 
Geconcludeerd kan worden dat de meeste bedrijven het aantal leerlingen dat ze in dienst hebben niet laten afhangen van de verwachte groei van het bedrijf. Dat geldt zowel voor BBL- als BOL-leerlingen. Hoewel de toekomstige behoefte aan personeel een belangrijk motief is om leerlingen op te leiden, is het kennelijk niet mogelijk om snel het aantal leerlingen aan te passen bij veranderingen in de groei.

Overigens blijkt in de praktijk dat in bepaalde sectoren de beschikbaarheid van bpvplaatsen conjunctuurgevoelig is. Hoewel uit bovenstaande tabellen het beeld naar voren komt dat bedrijven zeer terughoudend reageren op veranderende omstandigheden, zou een sterke groei in de sector dan dus toch tot een sterke groei van het aantal bpv-plaatsen leiden. De oorzaak hiervoor is waarschijnlijk dat BBLleerlingen gezien hun bijdrage aan de productiviteit al snel een aantrekkelijk substituut voor gekwalificeerd personeel vormen. Niet zozeer als een bedrijf zelf een groei doormaakt, maar met name als de markt voor gekwalificeerd personeel erg gespannen is, zal dus een groot aantal werkgevers in hun personeelswerving uitwijken naar leerlingen, om toch de gewenste bedrijfsomzet in stand te kunnen houden. Naast ontwikkelingen op bedrijfsniveau zal daardoor ook de personeelsschaarste in de sector als geheel de beschikbaarheid van bpv-plaatsen beïnvloeden. Deze invloeden zijn echter vaak erg kortstondig, zodat op de middel-lange termijn de structurele tendensen weer de overhand zullen krijgen. 


\section{De vraag naar gediplomeerden uit de BBL}

\subsection{Inleiding}

Sinds de invoering van de WEB (Wet Educatie en Beroepsonderwijs) zijn de opleidingen in wat voorheen het MBO en het leerlingwezen heette binnen één kader geplaatst. $\mathrm{Er}$ is daardoor een structuur ontstaan waarbij in principe op vier niveaus beroepsopleidingen worden verzorgd die dan wel hoofdzakelijk op school - de beroepsopleidende leerweg, BOL - dan wel hoofdzakelijk in de praktijk - de beroepsbegeleidende leerweg, BBL - kunnen worden gevolgd ${ }^{1}$. De eindtermen voor deze beide leerwegen - zoals die geformuleerd zijn in de kwalificatiestructuur - zijn echter gelijk, waardoor de gelijkwaardigheid van beide leerwegen vanuit deze optiek wordt gegarandeerd. Leerlingen uit beide leerwegen beschikken over de in de eindtermen geformuleerde kennis en vaardigheden die voor de uitoefening van het betreffende beroep van belang worden geacht.

Deze formele gelijkschakeling van de BOL en de BBL betekent overigens nog niet dat ook altijd de arbeidsmarktpositie van gediplomeerden uit beide leerwegen gelijk is. Onderwijs is immers een zeer complex proces. De verschillen tussen leerlingen als zij instromen in het onderwijs zijn heel groot en ook bij het leerproces zelf spelen veel meer factoren dan alleen de formele eindtermen een rol. Nijhof (1998) merkt in zijn overzichtsartikel over curricula en arbeidsmarktperspectieven reeds op dat het eindresultaat van een opleiding wordt bepaald door een viertal hoofdfactoren: eigenschappen van leerlingen, inputkenmerken, omgevingskenmerken en proceseigenschappen. Bij de eigenschappen van leerlingen zijn intelligentie, motivatie, leerstijl en locus of control belangrijke aspecten. Bij inputkenmerken noemt Nijhof naast de formele leerdoelen of eindtermen ook de gehanteerde pedagogiek, wijze van toetsen en de nominale studieduur. Bij omgevingskenmerken kan gedacht worden aan de beschikbare technologie, maar ook aan (regionale) economische ontwikkelingen. Gegeven deze drie startpunten, vormt echter de wijze waarop het leerproces plaatsvindt een belangrijke determinant van het eindresultaat. De wijze waarop een leerling gedurende zijn opleiding feedback krijgt, de begeleiding die hij krijgt, de werkervaring die hij opdoet, maar ook de wijze waarop op deze ervaring wordt gereflecteerd bepalen de ontwikkeling die een leerling doormaakt.

In dit leerproces verwerft een leerling niet alleen vakkennis en specifieke competenties die voor zijn beroep van belang zijn, maar ontwikkelt hij ook sociaalnormatieve kennis, communicatieve vaardigheden en leert hij te leren. Omdat de $B O L$ en $B B L$ sterk verschillen in de wijze waarop het leerproces wordt ingericht, valt te verwachten dat beide systemen sterk (kunnen) verschillen in het type leerling dat wordt aangetrokken, maar ook in het proces waarmee deze leerlingen kennis vergaren.

1. Opleidingen op niveau 4 in het kader van de BBL komen overigens nog nauwelijks voor. 
Het valt dan ook te verwachten dat werkgevers ondanks de formele equivalentie binnen de kwalificatiestructuur, wel degelijk een onderscheid maken tussen gediplomeerden van beide leerwegen. Deze afweging zal overigens zelf ook weer bepaald worden door een groot aantal factoren. Voor bepaalde leerlingen zal de BOL geschikter zijn dan de BBL, terwijl voor andere leerlingen de beroepsbegeleidende variant juist weer geschikter is. Daarnaast zal ook de aard van het beroep en het soort bedrijf invloed hebben op deze afwegingen. Om een goed beeld te krijgen van de consequenties die verwachte arbeidsmarktontwikkelingen hebben voor de arbeidsmarktpositie van beide leerwegen is daarom inzicht in dit afwegingsproces onontbeerlijk.

In dit hoofdstuk wordt daarom ingegaan op de voorkeuren die werkgevers hebben voor gediplomeerden uit beide leerwegen. Allereerst wordt in paragraaf 3.2, op basis van de literatuur, nagegaan welke oorzaken ten grondslag aan deze afweging tussen BBL- en BOL-gediplomeerden kunnen liggen. Vervolgens wordt in paragraaf 3.3 gekeken naar de feitelijke voorkeuren van werkgevers in verschillende bedrijfssectoren voor gediplomeerden van de ene dan wel de andere leerweg. Uiteraard wordt hierbij ook ingegaan op het onderscheid tussen het MKB en grotere bedrijven. De gegevens zijn gebaseerd op de BBL-enquête die het ROA in het kader van dit onderzoek heeft laten uitvoeren onder een groot aantal bedrijven. Om een meer gedetailleerd beeld van dit keuzeproces te krijgen is in aanvulling op deze grootschalige enquête een vignetonderzoek uitgevoerd. In paragraaf 3.4 wordt het afwegingsproces van bedrijven op basis van dit vignetonderzoek voor een tweetal sectoren - de garagesector en de zorgsector - uitgelicht. Bekeken wordt in welke mate de gevolgde leerweg van belang is als selectiecriterium, maar ook in welke mate andere kenmerken van kandidaten een rol spelen bij de keuze die werkgevers maken. De inzichten uit dit hoofdstuk zullen later in dit rapport als uitgangspunt dienen om de ontwikkelingen zoals die voor de komende jaren op de arbeidsmarkt worden voorzien, te vertalen naar de betekenis die zij hebben voor de BBL.

\subsection{Waarom nemen bedrijven BOL'ers of BBL'ers in dienst?}

Ofschoon de eindtermen zoals geformuleerd in de kwalificatiestructuur voor BOL en BBL gelijk zijn, blijken werkgevers veelal toch een zekere voorkeur te hebben voor werknemers die een bepaalde leerweg hebben gevolgd. $\mathrm{Er}$ is een aantal argumenten waarom werkgevers voorkeur kunnen hebben voor leerlingen uit een van beide trajecten. De argumenten hebben betrekking op het leerproces zelf en de competenties die daarmee worden verworven, maar ook op het sorteermechanisme dat ontstaat binnen een onderwijssysteem dat een keuzemogelijkheid tussen beide leerwegen biedt.

Allereerst het leerproces zelf. De BBL is een traject dat in hoge mate bepaald wordt door de werkervaring in de leerbedrijven. Leren op school heeft slechts een aanvullende functie op deze werkervaring en heeft vooral tot doel de kennis die in de praktijk is opgedaan terug te plaatsen in een breder kader. Zodoende gaat de leerling de theoretische achtergrond inzien van wat hij in het bedrijf leert zodat hij het 
geleerde ook in een andere context zal kunnen toepassen. Daarnaast zijn er uiteraard ook een aantal vakken die moeilijk in de beroepspraktijk kunnen worden aangeleerd. Ook voor dergelijke kennis - te denken valt aan talenkennis of kennis over relevante regelgeving - zorgen de lessen die in aanvulling op het praktijkleren worden gegeven. De omgeving waarin leerlingen de vakkennis op moeten doen is echter minder gestructureerd dan op school en niet in elk leerbedrijf zal het leerproces als zodanig centraal staan. Dat betekent dat de werkzaamheden die een leerling verricht niet altijd puur vanuit een pedagogische optiek worden geselecteerd, maar dat soms ook toevallige werkzaamheden die zich voordoen mede de inhoud van het curriculum bepalen. Hierdoor zal de kwaliteit van de leeromgeving meer variatie hebben dan op school en zal mogelijk ook meer variatie zitten in de specifieke aspecten van het vak die aan de orde zijn gekomen.

Bij de BOL voert schools leren de boventoon. In het onderwijs is ruim plaats voor stages, zodat de leerlingen kennis zullen maken met de praktijk, maar het primaat ligt toch bij het klassikale leren. De consequentie hiervan is dat - in tegenstelling tot de $B B L$ - hier juist de vertaalslag van leerboek naar praktijk een kwetsbaar punt vormt. Daarnaast zullen BOL-leerlingen veel minder dan BBL-leerlingen in aanraking komen met specifieke gewoontes en handigheden zoals die in een bepaald beroep worden gehanteerd en zal ook het inzicht in bedrijfsprocessen na het behalen van het diploma nog niet volop aanwezig zijn. BOL'ers zijn daardoor meer gewend aan leren buiten een specifieke context, maar lopen wellicht achter in de concrete vaardigheid binnen het vak.

Van der Velden en Lodder (1993) analyseren de vraag in hoeverre leerlingen uit de verschillende leerwegen een verschillende positie op de arbeidsmarkt hebben. Het blijkt in deze studie - die overigens betrekking heeft op de situatie voor de invoering van de WEB - dat de kansen voor de werknemers afkomstig uit het voltijdsonderwijs groter zijn dan die voor de werknemers uit het duale systeem. Dit impliceert dat werkgevers onder verschillende omstandigheden de voorkeur geven aan mensen uit een van beide routes. De verhouding waarin gediplomeerden uit de beide leerwegen aangenomen worden hangt af van het belang dat werkgevers voor diverse functies hechten aan de nadruk die binnen beide trajecten op de 'leer'- en de 'werk'-component valt. Op basis van bovenstaande overwegingen kan verwacht worden dat voor functies waarbij de nadruk ligt op eenzelfde groep vaardigheden, ze de voorkeur aan BBL-gediplomeerden geven, terwijl voor functies die meer gericht zijn op een breder, en minder vaststaand aantal taken, de voorkeur wordt gegeven aan BOL-gediplomeerden. Ook zou een werkgever in een omgeving die aan veranderingen onderhevig is, of dat naar verwachting zal worden, de voorkeur geven aan BOL-gediplomeerden, die over meer algemene vaardigheden en leercapaciteiten beschikken, of althans, verondersteld worden daarover te beschikken.

Van der Velden en Lodder wijzen er echter ook op dat er sprake kan zijn van een sorteermechanisme dat de voorkeuren van werkgevers kan beïnvloeden. In de economische literatuur worden dergelijke mechanismen aangeduid als 'signalling' en statistical discrimination. Als de BBL met name geschikt is voor leerlingen die over 
technische vaardigheden beschikken en de BOL een betere leerweg is voor de meer cognitief ingestelde leerlingen, dan verraadt de leerweg die men kiest iets over de aard van de leerling. Ook een meer cognitief ingestelde leerling die de BBL volgt zal daardoor mogelijk worden geassocieerd met vakbekwaamheid. Als een van de twee profielen door werkgevers hoger wordt aangeslagen dan de ander kan dit er toe leiden dat leerlingen een neiging krijgen de bijbehorende leerweg te volgen, ook al is dit voor hen vanuit pedagogisch perspectief niet optimaal. Zij hopen zo (wellicht onbewust) naar werkgevers uit te stralen dat ook zij over dit gewenste profiel beschikken. Dit effect, dat 'signalling' wordt genoemd, kan er toe leiden dat steeds meer leerlingen de als beter gewaardeerde leerweg kiezen. Alleen leerlingen voor wie de best gewaardeerde leerweg absoluut geen optie is kiezen dan nog voor de minst gewaardeerde leerweg. Op deze wijze kan één van beide leerwegen gemarginaliseerd worden. In het verleden heeft een dergelijke verschuiving van LBO naar MAVO geleid tot een enorme reductie van de belangstelling voor het lager beroepsonderwijs.

\subsection{Voorkeuren van werkgevers}

Om een beeld te krijgen van de wijze waarop werkgevers aankijken tegen gediplomeerden van de BBL en BOL zijn hen in de enquête een aantal vragen over beide groepen voorgelegd. Werkgevers is allereerst gevraagd om voor verschillende aspecten aan te geven wie daar beter op scoren, gediplomeerden van de BBL of van de BOL. Deze aspecten behelzen verschillende zaken die in de werksituatie van belang kunnen zijn. Een belangrijk aspect is ten eerste of iemand een goede vakkracht is. Daarnaast spelen ook nog andere factoren een rol in de beroepspraktijk. Gevraagd is naar het oordeel over probleemoplossen, flexibiliteit, leervermogen, inwerktijd en benodigde nascholing.

Tabel 3.1

Beoordeling van beide leerwegen op verschillende aspecten. Percentage bedrijven dat vindt dat BBL'ers of BOL'ers beter scoren of vindt dat er geen verschil is

\begin{tabular}{lccc}
\hline & $\begin{array}{c}\text { BBL } \\
\%\end{array}$ & $\begin{array}{c}\text { BOL } \\
\%\end{array}$ & $\begin{array}{c}\text { geen verschil } \\
\%\end{array}$ \\
\hline Wie zijn betere vakkrachten & 40 & 11 & 34 \\
Wie lossen sneller een probleem op & 37 & 11 & 39 \\
Wie zijn meer flexibel & 37 & 9 & 40 \\
Wie leren makkelijker nieuwe dingen bij & 19 & 20 & 41 \\
Wie zijn sneller ingewerkt & 47 & 10 & 30 \\
Wie hebben minder nascholing nodig & 23 & 25 & 36 \\
\hline
\end{tabular}

Tabel 3.1 geeft per aspect het percentage werkgevers aan dat vindt dat BBL'ers of BOL'ers beter scoren of dat er geen verschil is tussen gediplomeerden van beide leerwegen. Zeer duidelijk komt naar voren dat BBL'ers op de meeste aspecten beter scoren dan BOL'ers. Zo vindt rond de $40 \%$ van de bedrijven dat BBL'ers betere vakkrachten zijn, sneller een probleem oplossen en meer flexibel zijn. Nauwelijks verrassend is dat bijna de helft van de werkgevers vindt dat BBL'ers sneller zijn 
ingewerkt. Zij hebben ten slotte ook meer werkervaring dan BOL'ers omdat ze tijdens de opleiding al werkzaam waren. Op het gebied van nascholing en het vermogen om nieuwe zaken bij te leren scoren BBL'ers iets minder gunstig maar het verschil met BOL'ers is slechts gering. Respectievelijk $23 \%$ en $19 \%$ van de bedrijven heeft op dit vlak een voorkeur voor BBL'ers terwijl $25 \%$ en $20 \%$ van de bedrijven BOL'ers op dit front hoger aanslaat. Opvallend is overigens ook het grote aantal bedrijven dat aangeeft dat er geen verschil is tussen gediplomeerden van beide leerwegen. Voor bijna ieder aspect heeft minstens een op de drie bedrijven geen voorkeur voor een van beide leerwegen.

Tabel 3.2

Totale beoordeling van beide leerwegen door bedrijven met en zonder leerlingen. Percentage bedrijven dat vindt dat BBL'ers of BOL'ers beter scoren of dat neutraal is

\begin{tabular}{lccc}
\hline & $\begin{array}{c}\text { BBL } \\
\%\end{array}$ & $\begin{array}{c}\text { BOL } \\
\%\end{array}$ & $\begin{array}{c}\text { Neutraal } \\
\%\end{array}$ \\
\hline $\begin{array}{l}\text { Bedrijven met leerlingen } \\
\text { Bedrijven zonder leerlingen }\end{array}$ & 50 & 34 & 16 \\
Alle bedrijven & 53 & 18 & 28 \\
\hline
\end{tabular}

Zoals gezegd zal het afhankelijk zijn van de functie hoeveel belang bedrijven aan de verschillende aspecten hechten bij het selecteren van personeel. Om een totaal beeld te kunnen presenteren van de beoordeling van BBL'ers en BOL'ers veronderstellen we hier dat elk aspect even belangrijk is voor bedrijven. Op basis van de totale score over alle aspecten kunnen we concluderen dat meer dan de helft van de bedrijven in eerste instantie een voorkeur heeft voor BBL-gediplomeerden, ongeveer $20 \%$ voor BOL-gediplomeerden en iets meer dan een kwart vindt dat er geen verschil is tussen gediplomeerden van beide leerwegen.

Tabel 3.3

Totale beoordeling van beide leerwegen door bedrijven. Percentage bedrijven dat vindt dat BBL'ers of BOL'ers beter scoren of dat neutraal is

\begin{tabular}{lllcc}
\hline & & $\begin{array}{c}\text { BBL } \\
\%\end{array}$ & $\begin{array}{c}\text { BOL } \\
\%\end{array}$ & $\begin{array}{c}\text { Neutraal } \\
\%\end{array}$ \\
\hline \multirow{3}{*}{ Branche } & Industrie & 53 & 33 & 14 \\
& Garage & 58 & 29 & 13 \\
& Landbouw & 49 & 34 & 17 \\
& Bouw & 51 & 26 & 23 \\
& Horeca & 78 & 12 & 10 \\
& Zakelijke dienstverlening & 36 & 24 & 40 \\
& Groot-, detailhandel & 59 & 15 & 26 \\
Grootteklasse & Non-profit & 61 & 20 & 18 \\
& 1-9 werknemers & 52 & 20 & 17 \\
& 10-99 werknemers & 56 & 27 & 15 \\
& 100 of meer werknemers & 68 & 17 & 26 \\
\hline
\end{tabular}


Verwacht mag worden dat het oordeel over gediplomeerden sterk afhankelijk is van de ervaring die men met gediplomeerden van beide leerwegen heeft en daarom is het goed mogelijk dat bedrijven die zelf leerlingen opleiden anders oordelen dan bedrijven die dat niet doen. Uit tabel 3.2 blijkt dat bedrijven met BBL-leerlingen minder vaak neutraal staan tegenover beide leerwegen dan bedrijven zonder leerlingen. Kennis van zaken leidt dus tot een duidelijker oordeel over de kwaliteit van beide leerwegen.

Uit tabel 3.3 blijkt dat de score van BBL- en BOL-gediplomeerden afhangt van de branche. De BBL krijgt de beste inschatting in de horeca, terwijl de waardering voor de BBL het laagst is in de zakelijke dienstverlening. In laatsgenoemde branche zijn bovendien erg veel bedrijven die de BBL en BOL gelijk waarderen. Toch zijn er ook in deze branche per saldo meer bedrijven die BBL'ers beter vinden dan BOL'ers. Opvallend is verder dat de BBL wat beter scoort bij grote bedrijven dan bij het midden- en kleinbedrijf.

Het kwaliteitsoordeel heeft betrekking op de gemiddelde gediplomeerde van beide leerwegen. In de praktijk zal de geschiktheid van medewerkers echter niet alleen afhangen van de leerweg die men heeft gevolgd, maar zal er binnen beide groepen ook een aanzienlijke variatie bestaan. Het is goed mogelijk dat de kwaliteitsverdeling voor beide groepen elkaar voor een groot deel overlappen. In dat geval zijn de relatief goede BOL-gediplomeerden toch beter dan de relatief slechte BBLgediplomeerden. Uit tabel 3.4 blijkt dat uiteindelijke de voorkeur van een bedrijf inderdaad sterk afhangt van de eigenschappen van de persoon in kwestie. Maar liefst $75 \%$ van de werkgevers zegt dat de uiteindelijke voorkeur sterk afhankelijk is van de persoon. Van de bedrijven die wel een duidelijke voorkeur hebben, heeft het merendeel de voorkeur voor BBL-gediplomeerden.

Opvallend is ook dat in de horeca geen enkel bedrijf aangeeft het liefst een BOL'er aan te willen nemen. In de zakelijke dienstverlening geeft ruim $20 \%$ van de bedrijven aan het liefst een gediplomeerde van de BBL te willen aannemen. Bij de totale beoordeling scoorden BBL'ers in deze sector wat lager dan gemiddeld. Dit heeft te maken met het feit dat gediplomeerden van de BBL in deze sector erg laag scoren wat betreft het leervermogen. Blijkbaar hechten bedrijven echter weinig belang aan dit aspect bij de personeelsselectie wanneer ze snel iemand nodig hebben.

Hoewel BBL'ers bij grote bedrijven vaak beter scoren dan bij kleinere bedrijven, nemen grote bedrijven toch minder vaak gediplomeerde BBL'ers aan. Slechts $2 \%$ zegt de voorkeur voor een BBL'er te hebben indien er onmiddellijk behoefte is aan een nieuwe werknemer. Bij het midden- en kleinbedrijf is dit percentage respectievelijk $8 \%$ en $15 \%$. Waarschijnlijk hebben deze bedrijven vooral een voorkeur voor zelf opgeleide leerlingen van de BBL. Als ze toch een gediplomeerde extern moeten werven verdwijnt de voorsprong van de BBL. Daarnaast speelt ook de lagere score met betrekking tot het vermogen nieuwe zaken bij te leren een rol. Op dit punt scoren gediplomeerden van de BBL namelijk slechter in de middelgrote en grote bedrijven dan in de kleine bedrijven. 
Tabel 3.4

Voorkeur van werkgevers voor gediplomeerden van beide leerwegen indien er per onmiddellijk behoefte is aan een nieuwe medewerker

\begin{tabular}{llrrr}
\hline & BBL & BOL & $\begin{array}{c}\text { afhankelijk } \\
\text { van persoon } \\
\%\end{array}$ \\
& & $\%$ & $\%$ & 75 \\
Branche & Industrie & 12 & 8 & 78 \\
& Garage & 9 & 7 & 63 \\
& Landbouw & 11 & 4 & 82 \\
& Bouw & 17 & 7 & 62 \\
& Horeca & 15 & 8 & 76 \\
& Zakelijke dienstverlening & 21 & 5 & 77 \\
Grootteklasse & Groot-, detailhandel & 10 & 10 & 77 \\
& Non-profit & 8 & 6 & 75 \\
\hline \multirow{5}{*}{ Alle bedrijven } & 1-9 werknemers & 15 & 7 & \\
& 10-99 werknemers & 8 & 14 & \\
& 100 of meer werknemers & 2 & 6 & \\
& & 14 & &
\end{tabular}

Zoals gezegd zal de voorkeur sterk afhankelijk zijn van het soort functie. In functies waarbij de nadruk ligt op vakkennis zullen bedrijven eerder de voorkeur hebben voor iemand van de BBL terwijl in functies waar men steeds te maken krijgt met technologische veranderingen, het vermogen om nieuwe zaken bij te leren belangrijk is. In het laatste geval zullen werkgevers relatief vaker de voorkeur hebben voor een gediplomeerde van de BOL. Ook is belangrijk of men tijdelijk iemand nodig heeft of voor de lange termijn. In het laatste geval is het leervermogen, ook in verband met mogelijke doorgroei binnen het bedrijf van groter belang. Bedrijven is daarom ook gevraagd welk personeel ze zouden willen aannemen als ze tijdelijk behoefte hebben aan personeel (maximaal twee jaar) of structureel behoefte hebben aan een nieuwe medewerker. Het ging daarbij overigens niet alleen om BOL- en BBL-gediplomeerden maar om alle categorieën arbeid, waaronder ook leerlingen en stagiaires en hoger opgeleid personeel. Tabel 3.5 geeft voor bedrijven met en zonder leerlingen aan of ze bij een tijdelijke behoefte aan extra personeel BBL- en/of BOL gediplomeerden zouden aannemen. lets meer dan de helft van de bedrijven zou in dat geval BBL-gediplomeerden willen aannemen en meer dan éénderde BOL-gediplomeerden. Opvallend is dat bedrijven die leerlingen in dienst hebben zowel vaker BBL- als BOL-gediplomeerden willen aannemen dan bedrijven zonder leerlingen. Hier speelt waarschijnlijk dat deze bedrijven in het algemeen meer behoefte hebben aan gediplomeerden op het niveau van secundair beroepsonderwijs.

Uit tabel 3.6 blijkt vervolgens dat bij een structurele personeelsbehoefte iets minder vaak BBL-gediplomeerden worden aangenomen dan bij een tijdelijke behoefte aan personeel. Het verschil is echter minimaal. Ook het percentage van de bedrijven dat een BOL-gediplomeerde zou willen aannemen hangt niet af van de vraag of het gaat om een tijdelijke of een structurele behoefte. De relatieve voorkeur voor gediplomeerden van beide leerwegen verandert dus nauwelijks als er sprake is van een structurele personeelsbehoefte in plaats van een tijdelijke behoefte. 
Tabel 3.5

Bedrijf neemt BBL- of BOL-gediplomeerden bij tijdelijk extra personeelsbehoefte

\begin{tabular}{lcc}
\hline & $\begin{array}{c}\text { BBL } \\
\%\end{array}$ & $\begin{array}{c}\text { BOL } \\
\%\end{array}$ \\
\hline Bedrijven met leerlingen & 58 & 39 \\
Bedrijven zonder leerlingen & 52 & 35 \\
Alle bedrijven & 52 & 36 \\
\hline
\end{tabular}

Tabel 3.6

Bedrijf neemt BBL- of BOL-gediplomeerden bij structureel extra personeelsbehoefte

\begin{tabular}{lcc}
\hline & $\begin{array}{c}\text { BBL } \\
\%\end{array}$ & $\begin{array}{c}\text { BOL } \\
\%\end{array}$ \\
\hline Bedrijven met leerlingen & 56 & 43 \\
Bedrijven zonder leerlingen & 48 & 35 \\
Alle bedrijven & 49 & 36 \\
\hline
\end{tabular}

Geconcludeerd kan worden dat in de meeste sectoren het merendeel van de werkgevers gediplomeerden van de BBL hoger aanslaan dan gediplomeerden van de BOL. Echter, de gevolgde leerweg is slechts één van de selectiecriteria bij het aannemen van personeel. Driekwart van de bedrijven zegt immers dat de uiteindelijke voorkeur sterk afhankelijk zal zijn van de persoon.

\subsection{De voorkeuren van werkgevers nader bekeken: de garagesector en de zorg}

Om een beeld te krijgen van de rol die de gevolgde leerweg speelt in het totaal aan selectiecriteria zijn twee branches nader bestudeerd. Dit zijn de garagesector en de zorgsector (non-profit). In beide branches heeft het beroepsbegeleidende onderwijs een sterke traditie en is de bekendheid met beide leerwegen groot ${ }^{2}$. In de vorige paragraaf bleek al dat bedrijven die bekend zijn met beide leerwegen een meer uitgesproken voorkeur hebben voor één van beide leerwegen en dus minder vaak neutraal zijn. De homogeniteit van beide branches maakt het mogelijk om op basis van kleinschalig onderzoek toch betrouwbare uitspraken te doen. Het is daarbij met name van belang in hoeverre de resultaten van dit onderzoek de resultaten van de bedrijfsenquête ondersteunen.

In de genoemde branches is een kleinschalig vignetonderzoek onder bedrijven gehouden. De medewerker die verantwoordelijk is voor het werven van personeel bij een bedrijf kreeg een aantal gefingeerde profielen van kandidaten voor een functie voorgelegd en moest dan deze profielen rangschikken op basis van zijn voorkeur. Ook moest men aangeven welke kandidaten niet meer acceptabel zouden zijn voor

2. De voorganger in de BBL voor veel zorgopleidingen was het inservice onderwijs. 
de functie ${ }^{3}$. In de garagebedrijven bleek meestal de eigenaar de personeelswerving uit te voeren. Bij de zorginstellingen was dit in de regel een personeelsfunctionaris. De respondenten kregen globale informatie over de functie. Het ging steeds om twee verschillende functieniveaus, in de garagesector om een assistentautotechnicus (niveau 1) en een autotechnicus (niveau 2) en in de zorg om een helpende (niveau 2) of een verzorgende (niveau 3). Daarnaast kon het zowel om een tijdelijke aanstelling van maximaal een jaar of om een vaste aanstelling gaan.

Het profiel geeft zowel opleidingskenmerken als persoonlijke kenmerken van kandidaten. Tabel 3.7 geeft een voorbeeld van een gefingeerd profiel dat is gehanteerd in de zorgsector en een profiel dat is gehanteerd voor de garagesector. Het belangrijkste opleidingskenmerk is de gevolgde leerweg, BBL of BOL. Daarnaast is het niveau van de opleiding van belang. Het opleidingsniveau van de kandidaat is niet altijd gelijk gesteld aan het gevraagde functieniveau. Voor de functie van helpende konden bijvoorbeeld ook personen met een opleiding tot verzorgende kandidaat zijn. Dit maakt het mogelijk om na te gaan of de voorkeuren van werkgevers voor BBL of BOL ook verband houden met het opleidingsniveau.

Tabel 3.7

Voorbeelden van vignetten

\begin{tabular}{ll}
\hline & \\
Naam: & Ilona van der Stoel \\
Geslacht: & Vrouw \\
Leeftijd: & 25 \\
Nationaliteit: & Nederlands \\
Gevolgde opleiding: & BOL Verzorgende \\
Eindcijfer Verplegende elementen: & 8 \\
Eindcijfer Interactie in beroepssituaties: & 7 \\
Werkervaring: & Geen \\
Hobby: & Uitgaan \\
& \\
Naam: & Kevin van der Velden \\
Geslacht: & Man \\
Leeftijd: & 25 \\
Nationaliteit: & Nederlands \\
Gevolgde opleiding: & BBL Assistent autotechnicus \\
Eindcijfer Pers. en Maatsch. Vorming: & 7 \\
Eindcijfer (pers.) autotechniek: & 7 \\
Werkervaring: & Stage \\
Hobby: & Karten \\
& \\
\hline
\end{tabular}

De persoonlijke kenmerken zijn leeftijd, geslacht, nationaliteit en hobby's. Omdat in werkelijkheid het percentage vrouwen in de autobranche en het percentage mannen in de zorg erg laag is hebben we dit kenmerk niet gevarieerd binnen een sector. In de zorg zijn alleen vrouwelijke kandidaten en in de autobranche alleen mannen als gefingeerde kandidaten opgenomen. Alle kandidaten hebben de Nederlandse nationaliteit. Voor hobby's hebben we een onderscheid gemaakt tussen hobby's die een positief signaal kunnen zijn gezien de functie, en hobby's die los staan van de functie-eisen. In de autobranche is onderscheid gemaakt tussen technische hobby's

3. Voor een uitgebreide beschrijving van het vignet onderzoek zie Borghans et al. (2000) 
en sport. Omdat het in de zorg erg belangrijk lijkt te zijn om met mensen te kunnen omgaan is hier het onderscheid gemaakt tussen hobby's die men in een groep uitoefent en hobby's die individueel worden beoefend. Ten slotte varieert ook de werkervaring van kandidaten. Weliswaar doet het merendeel van de BOL'ers een stage en heeft het merendeel van de BBL'ers werkervaring, maar het is mogelijk dat ook een BOL'er voor de opleiding al enige tijd werkervaring in het vak heeft opgedaan.

Aan de hand van een regressieanalyse is voor beide sectoren bekeken in hoeverre bepaalde kenmerken de selectie beïnvloeden. Tabel 3.8 geeft de resultaten voor de zorgsector. Per kenmerk wordt aangegeven of een kenmerk een positieve, negatieve of helemaal geen invloed heeft op de relatieve voorkeur van de werkgevers voor een kandidaat.

Tabel 3.8

Impact van verschillende opleidings- en persoonskenmerken op de voorkeuren van werkgevers in de zorgsector

\begin{tabular}{ll}
\hline & Effect \\
\hline & \\
Leerweg BOL voor baan met vaste aanstelling & 0 \\
Leerweg BOL voor baan met tijdelijke aanstelling & - \\
Opleidingsniveau: basisberoepsopleiding & - \\
Opleidingsniveau: basisberoepsopleiding voor baan op niveau van & 0 \\
Cijfer voor vak 'Verplegende elementen' & + \\
Cijfer voor vak 'Interactie in beroepssituaties' & + \\
Stage & + \\
2 Jaar werkervaring & + \\
Leeftijd & + \\
Sociale hobby & 0
\end{tabular}

Als er sprake is van een tijdelijke functie hebben werkgevers een lichte voorkeur voor BBL-gediplomeerden ten opzichte van BOL-gediplomeerden. Bij een structurele behoefte is er geen significant verschil in voorkeur voor beide leerwegen. Werkgevers in de zorg hebben dus geen speciale voorkeur voor de BBL of BOL. Werkgevers hebben een voorkeur voor kandidaten met een opleiding voor verzorgende. Zoals verwacht willen werkgevers voor een positie van helpende wel iemand aannemen met een opleiding tot verzorgende maar andersom niet iemand met een opleiding tot helpende voor de functie van verzorgende. De eindresultaten van beide studieonderdelen hebben een sterke invloed op de relatieve voorkeur van werkgevers. Daarnaast is werkervaring erg bepalend voor de voorkeur en in iets mindere mate de stage. Verder hebben werkgevers een voorkeur voor wat oudere kandidaten. Hobby's hebben weinig invloed. Geconcludeerd kan worden dat in de zorg de gevolgde leerweg maar van beperkt belang is, andere kenmerken van kandidaten hebben veel meer invloed. Wel hebben BBL-gediplomeerden mogelijk de voorkeur in tijdelijke banen. Blijkbaar is dan hun relatief snelle inzetbaarheid een pré. 
Tabel 3.9 geeft vervolgens de resultaten voor de autobranche. Opvallend is dat in deze branche werkgevers de voorkeur voor iemand van de BOL hebben indien het gaat om een tijdelijke baan. Als het gaat om een structurele baan is er wederom weinig verschil in relatieve voorkeur van werkgevers voor de BBL dan wel de BOL. Ook in deze sector hebben werkgevers de voorkeur voor kandidaten met een zo hoog mogelijk opleidingsniveau. Cijfers zijn erg belangrijk, maar zoals verwacht heeft het cijfer voor het vakspecifieke onderdeel meer impact dan het cijfer voor het meer algemene studieonderdeel. Werkervaring is, zoals verwacht ontzettend belangrijk en in iets mindere mate de stage ook. In deze branche selecteren werkgevers niet op leeftijd. Hobby is wel een belangrijk selectiecriterium. Kandidaten met een technische hobby hebben de voorkeur boven kandidaten die aan sport doen.

De resultaten van het vignetonderzoek valideren de resultaten van de grootschalige bedrijfsenquête. Werkgevers selecteren slechts in beperkte mate op basis van de gevolgde leerweg. Andere kenmerken van kandidaten zijn veel belangrijker. Dit betekent dus dat de BBL en BOL, zoals beoogd in de WEB, door werkgevers in belangrijke mate als elkaars substituten worden gezien.

Tabel 3.9

Impact van verschillende opleidings- en persoonskenmerken op de voorkeuren van werkgevers in de garagebranche

Effect

Leerweg BOL voor baan met vaste aanstelling

Leerweg BOL voor baan met tijdelijke aanstelling

Opleidingsniveau: assistentenopleiding

Opleidingsniveau: assistentenopleiding voor baan op niveau van assistentenopleiding

Cijfer voor vak persoonlijke/maatschappelijke vorming

Cijfer voor vak autotechniek

Stage

2 Jaar werkervaring

Leeftijd

Technische hobby

0

$+$

0
+
+
+
+
+
+ 


\section{Het aanbod van leerlingen en gediplomeerden}

\subsection{Inleiding}

In de vorige twee hoofdstukken zijn respectievelijk de vraag naar leerlingen voor de BBL en de vraag naar gediplomeerden van de BBL aan bod gekomen. Tegenover deze vraag staat uiteraard het aanbod van leerlingen en gediplomeerden. In dit hoofdstuk zal worden ingegaan op het aanbod. Er worden prognoses gepresenteerd voor zowel de verwachte aantallen leerlingen die de komende jaren op zoek gaan naar een bpv-plaats als de uitstroom van gediplomeerden uit de BBL.

Paragraaf 4.2 zal de afwegingen behandelen die leerlingen kunnen maken bij de keuze om een middelbare beroepsopleiding te volgen via de beroepsopleidende dan wel de beroepsbegeleidende leerweg. In de paragraaf 4.3 komt vervolgens het verwachte aanbod van leerlingen in de periode 1999-2004 aan de orde. Deze prognoses zijn hoofdzakelijk gebaseerd op gegevens uit de onderwijsrekeningen van het CBS en de Referentieraming 1999 van het Ministerie van Onderwijs, Cultuur en Wetenschappen. In paragraaf 4.4 komt ten slotte het verwachte aanbod van gediplomeerden aan bod dat de komende vijf jaar de arbeidsmarkt zal gaan betreden. Basis voor deze prognoses vormen de prognoses voor instroom van schoolverlaters uit het door het ROA gepubliceerde rapport De Arbeidsmarkt naar Opleiding en Beroep tot 2004. Tevens worden in deze paragraaf enkele indicatoren besproken die de arbeidsmarktpositie van gediplomeerde BBL-schoolverlaters weergeven.

\subsection{Leerlingen in opleiding}

$\mathrm{Na}$ het afronden van een VMBO-opleiding gaan veel leerlingen een vervolgopleiding in het secundair beroepsonderwijs volgen. Hierbij kan men vrijwel altijd kiezen tussen enerzijds de beroepsopleidende leerweg (BOL) en anderzijds de beroepsbegeleidende leerweg $(\mathrm{BBL})$. Uit de literatuur komt naar voren dat deze keuze tussen beide leerwegen in sterke mate samenhangt met de manier waarop deze leerlingen het beste dingen leren en de houding die men heeft ten aanzien van school. Zoals reeds eerder is opgemerkt zullen meer cognitief geörienteerde leerlingen over het algemeen een voorkeur voor de BOL hebben terwijl meer praktische ingestelde jongeren die geen zin meer hebben om in de klas te moeten zitten, sneller de BBL kiezen.

De keuze voor een van beide leerwegen blijkt voor een groot gedeelte afhankelijk te zin van de 'schoolloopbaan' en daarmee indirect van de leeftijd van degene die een middelbare beroepsopleiding wil volgen. Uit eerder onderzoek (Smits, 1999) is gebleken dat personen die ervoor kiezen om een opleiding via de BBL te gaan volgen in het algemeen ouder zijn dan degenen die dezelfde opleiding via de BOL gaan volgen. Deze hogere leeftijd van instromers in de BBL is een gevolg van het feit dat deze personen vaak reeds werkervaring hebben opgedaan in een bedrijf. $\mathrm{Na}$ 
hun middelbare schooltijd zijn zij de arbeidsmarkt opgegaan en na een aantal jaren van werken kan op eigen initiatief of op initiatief van werkgeverszijde besloten worden om alsnog een opleiding te gaan volgen. Naast het feit dat de structuur van de BBL beter aansluit bij de werksituatie, de BBL bestaat namelijk voor $80 \%$ uit praktijk en $20 \%$ uit school, is ook het feit dat men loon ontvangt een reden om te kiezen voor de BBL-variant.

Echter, ook voor schoolverlaters blijkt er een duidelijke tweedeling te zijn tussen degenen die een BBL-opleiding en degenen die een BOL-opleiding volgen. Het lijkt er op dat veel leerlingen de twee leerwegen niet als een serieus alternatief zien. Voor zover de leerplicht geen belemmeringen met zich meebrengt, blijken jongeren die graag een opleiding in de BBL willen volgen, als ze geen leerplaats weten te krijgen eerder een andere baan te aanvaarden dan dat ze alsnog via de BOL gaan leren (zie Borghans en Smits, 1996).

\subsection{Het aanbod van leerlingen naar opleidingstype}

Tabel 4.1 presenteert de prognoses voor de instroom in de verschillende BBLopleidingstypen voor de komende vijf jaar. Zoals in de inleiding al is geschreven zijn deze prognoses gebaseerd op gegevens uit de Onderwijsrekeningen van het CBS en de Referentieraming 1999.

Uit de tabel blijkt dat er grote verschillen bestaan in instroomcijfers voor de verschillende BBL-opleidingstypen. De grootste absolute instroom in een BBL-opleiding zal werktuigbouw en mechanische techniek kennen. Tevens zien we een redelijk grote absolute instroom in opleidingstypen die tot de sector dienstverlening en gezondheidszorg worden gerekend.

De verwachtingen over de instroom in de $B B L$ zijn uiteraard in sterke mate afhankelijk van de deelname aan vooropleidingen op dit moment. Tabel 4.2 toont de herkomst van de mensen die in de periode 1999-2004 een opleiding via de BBL zullen volgen.

VMBO is, zoals verwacht kan worden, vanuit het onderwijs de 'hofleverancier' van de $\mathrm{BBL}$. In totaal zal de instroom uit het VMBO naar verwachting 117.000 mensen bedragen. Opmerkelijk is dat ook nog bijna 14.000 mensen zonder diploma, met dus alleen basisonderwijs, de BBL in zullen stromen. Daarnaast is er een redelijk omvangrijke groep leerlingen afkomstig uit een andere opleiding in het secundair beroepsonderwijs. Het grootste deel van de BBL-instroom, ruim de helft, bestaat echter uit mensen die reeds werkzaam zijn. Dit aantal bedraagt maar liefst 175.700 personen. Dit cijfer bevestigt dat een substantieel deel van de BBL-leerlingen vaak voordat met de opleiding begonnen wordt reeds werkervaring heeft opgedaan en op eigen initiatief of op initiatief van hun werkgever alsnog een kwalificatie in het secundair beroepsonderwijs wil behalen. Vanuit een reguliere baan gaat men dus een opleiding via de BBL volgen. Een overweging die hierbij een rol zal spelen is dat men op deze manier, met een relatief kleinere onderwijsinspanning de ervaring die 
men heeft opgedaan tijdens het werk, om kan zetten in een erkende kwalificatie. Voor iemand die reeds werk heeft zal het moeilijk zijn om via de beroepsopleidende leerweg een kwalificatie binnen het secundair beroepsonderwijs te behalen. In zekere zin fungeert de BBL daarmee als een methode voor de erkenning van verworven kwalificaties (Elders Verworven Competenties, EVC). De BBL brengt in beeld op welk niveau de kennis en vaardigheden van betrokkenen zich bevinden en vult waar nodig dit bereikte peil aan tot het niveau dat nodig is voor een volwaardige kwalificatie. Uiteraard zal met name het theoriegedeelte van de opleiding nog bijdragen aan de kennis van deze groep BBL'ers.

Tabel 4.1

Prognose instroom in BBL, 1999-2004

\begin{tabular}{|c|c|}
\hline Opleidingstype & Instroom BBL \\
\hline $\begin{array}{l}\text { Landbouw en natuurlijke omgeving } \\
\text { landbouw en veeteelt } \\
\text { milieu en groene ruimte }\end{array}$ & $\begin{array}{r}12.500 \\
6.800\end{array}$ \\
\hline $\begin{array}{l}\text { Techniek } \\
\text { laboratorium } \\
\text { bouw } \\
\text { grond-, weg- en waterbouw } \\
\text { installatietechniek } \\
\text { werktuigbouw en mechanische techniek } \\
\text { fijnmechanische techniek } \\
\text { motorvoertuigtechniek } \\
\text { vliegtuigtechniek } \\
\text { operationele techniek } \\
\text { ektrotechniek } \\
\text { grafische techniek } \\
\text { procestechniek } \\
\text { brood en banket } \\
\text { levensmiddelentechniek/vleesverwerking } \\
\text { vervoer en logistiek }\end{array}$ & $\begin{array}{r}40.900 \\
2.700 \\
17.200 \\
42.300 \\
1.500 \\
6.500 \\
1.700^{-} \\
11.500 \\
3.500 \\
3.500 \\
3.600 \\
4.700 \\
4.600\end{array}$ \\
\hline $\begin{array}{l}\text { Dienstverlening en gezondheidszorg } \\
\text { dokters-, tandarts- en dierenartsassistent } \\
\text { apothekersassistent } \\
\text { verpleging } \\
\text { sociaal-cultureel } \\
\text { verzorging } \\
\text { uiterlijke verzorging } \\
\text { horeca } \\
\text { beweging en therapie }\end{array}$ & $\begin{array}{r}4.500 \\
9.600 \\
10.800 \\
6.900 \\
10.500 \\
26.600 \\
24.700 \\
8.700\end{array}$ \\
\hline $\begin{array}{l}\text { Economie } \\
\text { administratie } \\
\text { handel } \\
\text { secretariaat } \\
\text { toerisme en recreatie }\end{array}$ & $\begin{array}{r}21.600 \\
14.900 \\
16.000\end{array}$ \\
\hline $\begin{array}{l}\text { Openbare orde en veiligheid } \\
\text { openbare orde en veiligheid }\end{array}$ & - \\
\hline
\end{tabular}

De streepjes in de tabel zijn ingevoegd voor die opleidingstypen waarvoor geen betrouwbare prognoses gemaakt konden worden.

Bron: ROA 
Een andere reden die de populariteit van de BBL onder personen die al een baan hebben kan verklaren is dat de kwalificatie in het secundair beroepsonderwijs ook kan worden gezien in het kader van up-grading. De ontwikkelingen in de jaren '90 laten een tendens zien dat de door werkgevers gestelde eisen verder toenemen. De snelle technologische ontwikkelingen leiden tot een toenemende complexiteit van veel functies. Daarnaast bewerkstelligen technologische vernieuwingen vaak ook organisatorische veranderingen, die op hun beurt de kwalificatie-eisen verder doen stijgen. Bovendien maakt massa-productie plaats voor op de consument afgestemd maatwerk waardoor de kwaliteit van de geleverde goederen en diensten hoger dient te zijn. In reactie daarop verwachten steeds meer bedrijven - ook van het zittend personeel - dat zij minstens een kwalificatie in het secundair beroepsonderwijs bezitten. De grote deelname aan BBL door mensen die al een reguliere baan hebben zal daardoor ook met deze ontwikkeling te maken hebben.

Tabel 4.2

Prognose herkomst instroom BBL, 1999-2004

\begin{tabular}{lc}
\hline Herkomst & Aantal \\
\hline & \\
Basisonderwijs & 13.900 \\
VMBO theorie & 20.500 \\
VMBO landbouw en natuurlijke omgeving & 12.900 \\
VMBO bouwtechniek & 17.000 \\
VMBO metaal: mechanische techniek & 13.400 \\
VMBO voertuigentechniek & 1.700 \\
VMBO elektrotechniek & 2.700 \\
VMBO grafische techniek & 600 \\
VMBO brood en banket & 2.100 \\
VMBO consumptief en levensmiddelentechniek & 9.200 \\
VMBO transport en logistiek & 2.000 \\
VMBO administratie, handel en mode & 11.200 \\
VMBO (uiterlijke) verzorging & 8.600 \\
HAVO/ VWO & 3.500 \\
MBO laboratorium & 2.500 \\
MBO bouw & 2.800 \\
MBO werktuigbouw en mechanische techniek & 1.800 \\
MBO techniek overig & 1.400 \\
MBO sociaal-cultureel & 3.800 \\
MBO verzorging & 1.700 \\
MBO administratie & 1.000 \\
MBO handel & 500 \\
MBO secretariaat & 1.100 \\
MBO toerisme en recreatie & 500 \\
MBO openbare orde en veiligheid & 1.800 \\
MBO overig & 3.200 \\
Arbeidsmarkt & 175.700 \\
& \\
\hline BrOn: ROA &
\end{tabular}

Bron: ROA

\subsection{Het aanbod van gediplomeerden naar opleidingstype}

In de vorige paragraaf is het aanbod van leerlingen die willen starten met een BBLopleiding aan de orde gekomen. In deze paragraaf komt het aanbod van gediplomeerden aan bod. Dit aanbod van gediplomeerde schoolverlaters van de BBL is gebaseerd op de prognoses zoals die gepubliceerd zijn in De Arbeidsmarkt naar 
Opleiding en Beroep tot 2004. In dit rapport staat de arbeidsmarktinstroom van gediplomeerden vanuit het secundair beroepsonderwijs in zijn totaal gepresenteerd. Basis voor deze instroomprognoses zijn de Referentieraming 1999 van het Ministerie van Onderwijs, Cultuur en Wetenschappen. Om de verwachte instroom van gediplomeerden vanuit de beroepsbegeleidende leerweg te prognosticeren is verder gebruik gemaakt van de Onderwijsrekeningen van het CBS.

Tabel 4.3

Arbeidsmarktinstroom Gediplomeerden 1999-2004

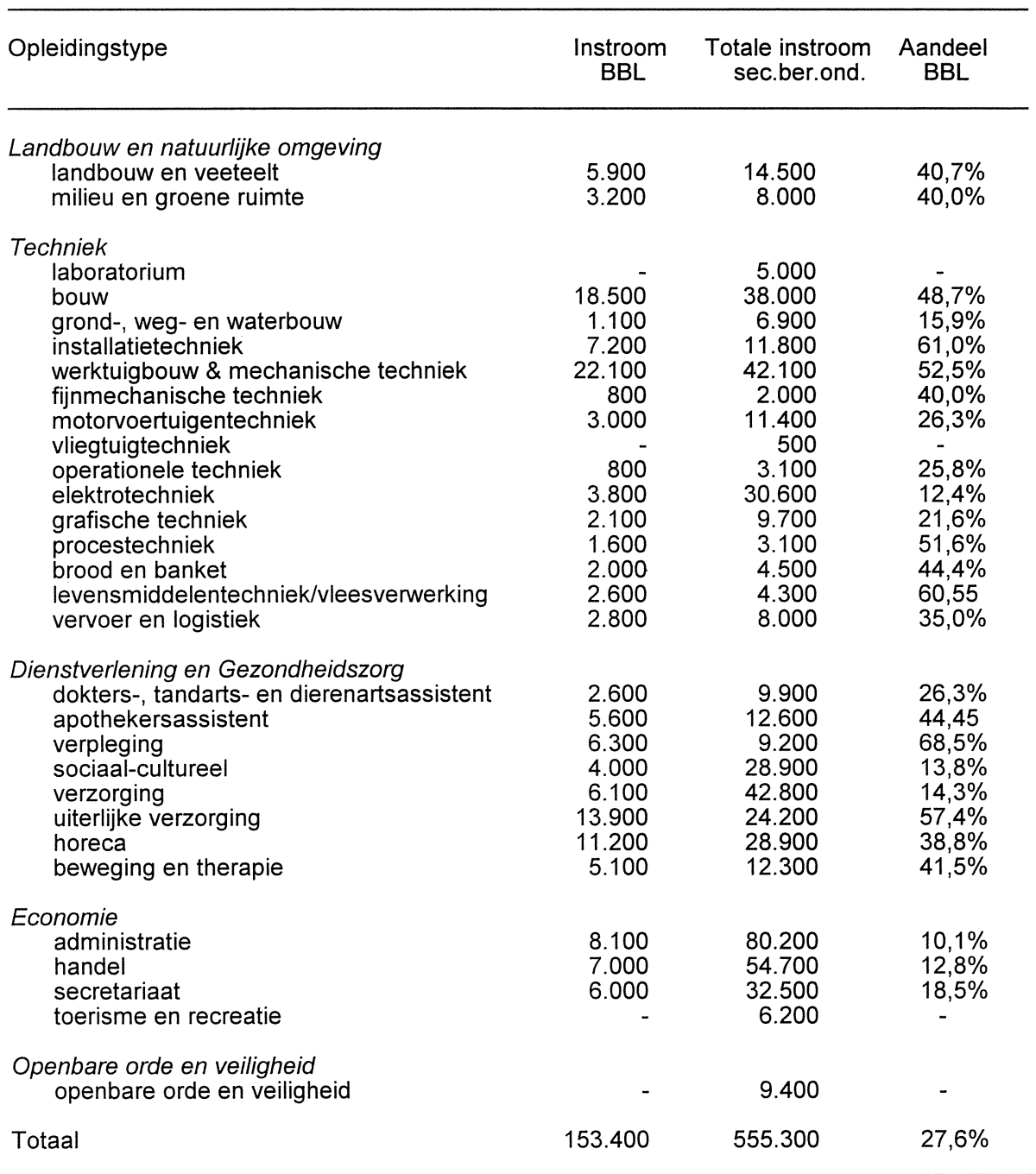

De streepjes in de tabel zijn ingevoegd voor die opleidingstypen waarvoor geen betrouwbare prognoses gemaakt konden worden.

Bron: ROA 
Om de instroom van gediplomeerden uit de BBL in perspectief te plaatsen zal eerst het totale verwachte arbeidsaanbod voor de periode 1999-2004 in de BVE-sector in beeld worden gebracht. Het gaat hierbij om mensen die de komende vijf jaar hun diploma behalen en zich daadwerkelijk aanbieden op de arbeidsmarkt. In de komende vijf jaar zullen naar verwachting circa 1.550 .000 schoolverlaters de arbeidsmarkt gaan betreden. In totaal kan met deze instroom van schoolverlaters jaarlijks ongeveer $4,3 \%$ van de werkende beroepsbevolking worden ververst. Van deze schoolverlaters zijn er circa 602.700 afkomstig uit het secundair beroepsonderwijs. Met deze instroom kan jaarlijks circa $4,2 \%$ worden ververst.

In de periode 1999-2004 zullen naar verwachting circa 163.000 schoolverlaters vanuit de $B B L$ de arbeidsmarkt opstromen. Dit betreft $27,1 \%$ van het totale aantal schoolverlaters op het niveau van secundair beroepsonderwijs. In vergelijking met de afgelopen vijf jaar (1993-1998) is dit aantal gediplomeerden vanuit de BBL zeer licht gedaald, toen bedroeg het aantal schoolverlaters nog 176.300 personen, terwijl het totale aantal schoolverlaters uit het secundair beroepsonderwijs destijds 623.100 bedroeg; dit komt neer op een percentage van $28,3 \%$. Tabel 4.3 geeft de aantallen gediplomeerden per opleidingstype die of via de BBL of via de BOL hun diploma hebben behaald. Daarnaast geeft deze tabel ook het aandeel van BBL weer in het totale aantal gediplomeerden op het niveau van secundair beroepsonderwijs.

Uit de tabel valt af te leiden dat het aandeel van de beroepsbegeleidende leerweg in het totale schoolverlatersaanbod van het secundair beroepsonderwijs circa een kwart bedraagt. Voor een aantal opleidingen geldt dat het aandeel BBL in het totale secundaire beroepsonderwijs meer dan $50 \%$ bedraagt. Het grootste aandeel wordt bereikt voor verpleging waar maar liefst $68,5 \%$ van de gediplomeerde schoolverlaters uit de BBL komt. Dit is niet verwonderlijk omdat traditioneel gezien verpleging het opleidingstype was dat vooral in de BBL-variant werd gevolgd, de zogenoemde in-service opleiding. Tegenover dit grote aandeel BBL-schoolverlaters voor verpleging staat het opleidingstype administratie waarvoor het aandeel van de BBL slechts $10,1 \%$ bedraagt. Bij dit opleidingstype wordt vooral theoretische kennis opgedaan die relatief makkelijk om te zetten is naar de praktijk. De leerlingwezentraditie is hierdoor minder sterk geworteld.

\section{Aansluiting opleiding en beroep}

Op basis van de schoolverlatersenquête RUBS wordt nu vervolgens een beeld gegeven van de arbeidsmarktintrede van schoolverlaters van de BBL- en BOL. Veel schoolverlaters van de BBL kunnen bij hun leerbedrijf blijven werken, in 1997 was dat maar liefst $47 \%$ (zie Smits 1999). Vaak betreft dit schoolverlaters die al voor de opleiding bij het bedrijf werkzaam waren. De positie van BBL-schoolverlaters verschilt daarmee wezenlijk van die van BOL-schoolverlaters die meestal wel nog op zoek moeten naar een baan. Verwacht mag worden dat de arbeidsmarktintrede van BBL'ers over het algemeen soepeler verloopt dan dat van BOL'ers. Daar zij vaak in de functie waarin zij zijn opgeleid blijven werken zal tevens de aansluiting tussen opleiding en beroep voor BBL'ers vaak beter zijn. In de schoolverlatersenquête 


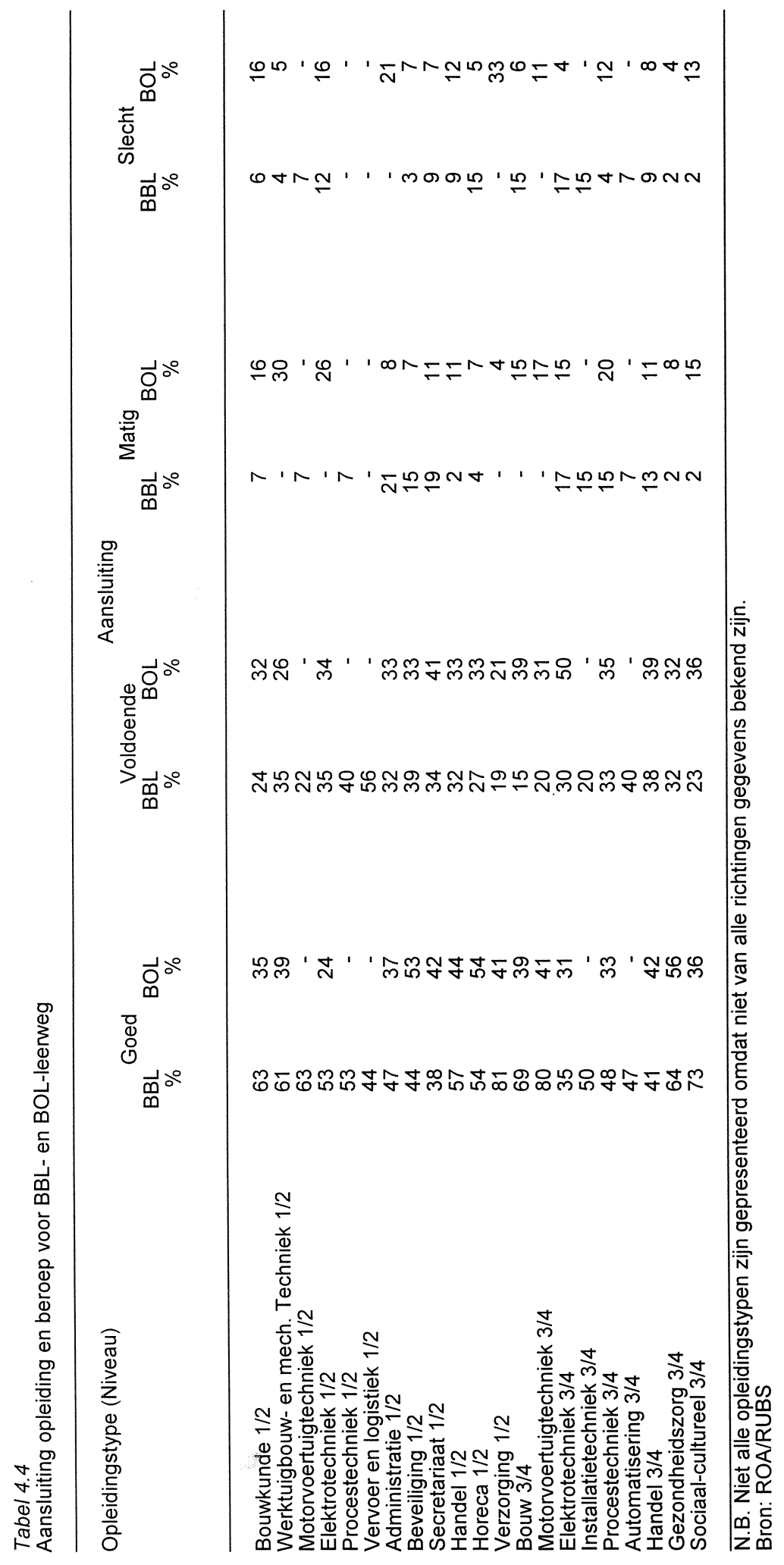


RUBS is aan zowel gediplomeerden van BBL-opleidingen als aan gediplomeerden van $\mathrm{BOL}$-opleidingen gevraagd hoe de aansluiting tussen genoten opleiding en beroep is. Tabel 4.4 presenteert deze gegevens.

Het blijkt dat bij de meeste opleidingstypen de aansluiting voor BBL inderdaad beter is dan voor BOL. De aansluiting tussen opleiding en beroep van de BBL-variant van verzorging op niveau 1 of 2 wordt bijvoorbeeld door maar liefst $81 \%$ van de ondervraagde gediplomeerde schoolverlaters als goed getypeerd, bij de BOL is dit slechts $41 \%$. Er zijn echter ook opleidingstypes waar weinig verschil is tussen BBL en BOL. Dat geldt voor horeca opleidingen op niveau $1 / 2$ en handel opleidingen op niveau 3/4. Er zijn zelfs enkele opleidingen waarbij de aansluiting voor BOL duidelijk beter is. Meer dan $80 \%$ van de BOL-schoolverlaters van de opleiding secretariaat op niveau $1 / 2$ noemt de aansluiting voldoende of goed terwijl slechts iets meer dan $70 \%$ van de BBL-schoolverlaters dit zegt. Dit is ook precies een opleiding waarin de leerlingwezentraditie minder sterk geworteld is. Blijkbaar is hier praktijkervaring minder belangrijk dan theoretische kennis voor een goede start op de arbeidsmarkt.

\section{Beloning}

Een tweede indicator om de arbeidsmarktpositie van gediplomeerde schoolverlaters van de BBL te vergelijken met de positie van gediplomeerde BOL-schoolverlaters is het gemiddelde bruto-uurloon. Tabel 4.5 schetst een vergelijking tussen het gemiddelde bruto-uurloon voor schoolverlaters van respectievelijk BBL en BOL.

Tabel 4.5

Beloning gediplomeerde schoolverlaters BBL en BOL

\begin{tabular}{lcc}
\hline Opleidingstype (Niveau) & \multicolumn{2}{c}{$\begin{array}{c}\text { Bemiddeld bruto-uurloon guldens } \\
\text { BBL }\end{array}$} \\
\hline & & - \\
Bouw $1 / 2$ & 19,38 & 14,10 \\
Werktuigbouw en mechanische techniek 1/2 & 14,87 & - \\
Motorvoertuigtechniek 1/2 & 12,38 & 12,08 \\
Elektrotechniek 1/2 & 14,59 & - \\
Procestechniek 1/2 & 25,89 & - \\
Vervoer en logistiek 1/2 & 14,93 & 15,93 \\
Administratie 1/2 & 24,86 & 18,83 \\
Beveiliging 1/2 & 17,20 & 14,51 \\
Secretariaat 1/2 & 15,85 & 11,04 \\
Handel 1/2 & 11,91 & 12,12 \\
Horeca 1/2 & 15,10 & 11,93 \\
Verzorging 1/2 & 17,37 & 18,17 \\
Bouw 3/4 & 23,73 & 16,54 \\
Motorvoertuigtechniek 3/4 & 19,13 & 18,02 \\
Elektrotechniek 3/4 & 21,18 & - \\
Installatietechniek 3/4 & 20,15 & 19,72 \\
Procestechniek 3/4 & 31,70 & - \\
Automatisering 3/4 & 19,85 & 14,29 \\
Handel 3/4 & 15,49 & 16,40 \\
Gezondheidszorg 3/4 & 20,06 & 17,51 \\
Sociaal-cultureel 3/4 & 17,11 & \\
& &
\end{tabular}

Bron: ROA/RUBS 
Uit bovenstaande tabel blijkt dat gediplomeerde schoolverlaters van de BBL gemiddeld per uur meer verdienen dan schoolverlaters van de BOL met hetzelfde opleidingstype. Bij sommige opleidingstypen wordt fors meer verdiend door BBL'ers dan BOL'ers, zo ligt het gemiddelde uurloon voor een gediplomeerde $B B L$ procestechniek ruim anderhalf keer zo hoog als voor een gediplomeerde $B O L$ procestechniek. Deze hogere uurlonen voor gediplomeerde schoolverlaters BBL kunnen van twee factoren afhankelijk zijn: gediplomeerde BBL'ers zijn over het algemeen ouder zodat zij niet meer in het minimumjeugdloon vallen. Daarnaast hebben zij ook vaker werkervaring en meer praktijkervaring wat zich eveneens vertaalt in een hoger brutouurloon.

Indien de twee arbeidsmarktindicatoren die hier boven besproken worden, aansluiting opleiding-arbeidsmarkt en bruto-uurloon, in ogenschouw worden genomen dan blijkt dat schoolverlaters van de BBL wat deze twee indicatoren betreft een betere positie op de arbeidsmarkt hebben dan schoolverlaters van de BOL. Uit onderzoek van Borghans en Smits (1996) en Smits (1999) kwam echter naar voren dat er een duidelijke splitsing is tussen degenen die het dienstverband na afloop van de opleiding bij dezelfde werkgever voortzetten en degenen die op zoek moeten naar ander werk. De laatste groep blijkt in de praktijk juist een zwakkere positie op de arbeidsmarkt in te nemen. 


\title{
5. Confrontatie van vraag en aanbod
}

\author{
5.1 Inleiding
}

In voorgaande hoofdstukken is ingegaan op de determinanten van de vraag naar leerlingen en gediplomeerden van de BBL. Op basis van de resultaten uit deze hoofdstukken worden in dit hoofdstuk prognoses voor zowel het aanbod van bpvplaatsen als de vraag naar BBL-gediplomeerden opgesteld. Allereerst zal echter een beeld worden gegeven van de actuele situatie met betrekking tot de werkgelegenheid voor mensen op het niveau van het secundair beroepsonderwijs. Vervolgens wordt ingegaan op de ontwikkelingen in de beschikbaarheid van bpv-plaatsen. Tot slot wordt gekeken naar de verwachte ontwikkelingen voor gediplomeerden op het niveau van het secundair beroepsonderwijs en de betekenis van deze ontwikkelingen voor de arbeidsmarktperspectieven voor BBL-gediplomeerden. Uiteraard wordt dit arbeidsmarktperspectief van de BBL in relatie gebracht tot de perspectieven zoals die voor de BOL worden voorzien.

\subsection{De actuele situatie op de arbeidsmarkt}

In tabel 5.1 wordt een overzicht gegeven van de werkgelegenheid voor opleidingstypen in het secundair beroepsonderwijs. Na jaren van forse groei is de werkgelegenheid voor werkenden op dit niveau de laatste jaren in rustiger vaarwater terecht gekomen. Achter deze zich stabiliserende werkgelegenheidsontwikkelingen gaan echter twee elkaar tegenwerkende tendensen schuil. Aan de ene kant neemt de werkgelegenheid voor ongediplomeerden en VBO'ers in een fors tempo af. Steeds meer wordt duidelijk dat op de Nederlandse arbeidsmarkt voor vrijwel al het werk een secundaire beroepsopleiding het basisniveau aan het worden is. $\mathrm{Er}$ is de laatste tijd sprake van een behoorlijke upgrading. Hierbij speelt ook de BBL een belangrijke rol, omdat zoals reeds werd opgemerkt, een aanzienlijk deel van de leerlingen een opleiding in het kader van de BBL volgt vanuit een normale arbeidsrelatie. Het bedrijf stelt hierbij dus niet een bpv-plaats beschikbaar waarvoor alsnog een leerling moet worden geworven, maar hanteert de BBL als faciliteit om zittende medewerkers een hoger kwalificatieniveau te laten verwerven.

Tegenover deze afnemende werkgelegenheid voor VBO en ongediplomeerden staat echter ook een duidelijke tendens bij bedrijven in andere marktsegmenten, om de opleidingseisen te verhogen van secundair onderwijs naar $\mathrm{HBO}$. Waar zij vroeger MBO'ers wierven nemen zij thans HBO'ers aan en van het zittende personeel wordt vaak verwacht dat ook zij hun kwalificatieniveau verhogen. Omdat deze ontwikkelingen sterk verschillen per sector, loopt ook de werkgelegenheidsontwikkeling bij de verschillende opleidingstypen in het secundair beroepsonderwijs sterk uiteen. 
Tabel 5.1

Aantal werkenden per opleidingstype, gemiddelde 1997-1998

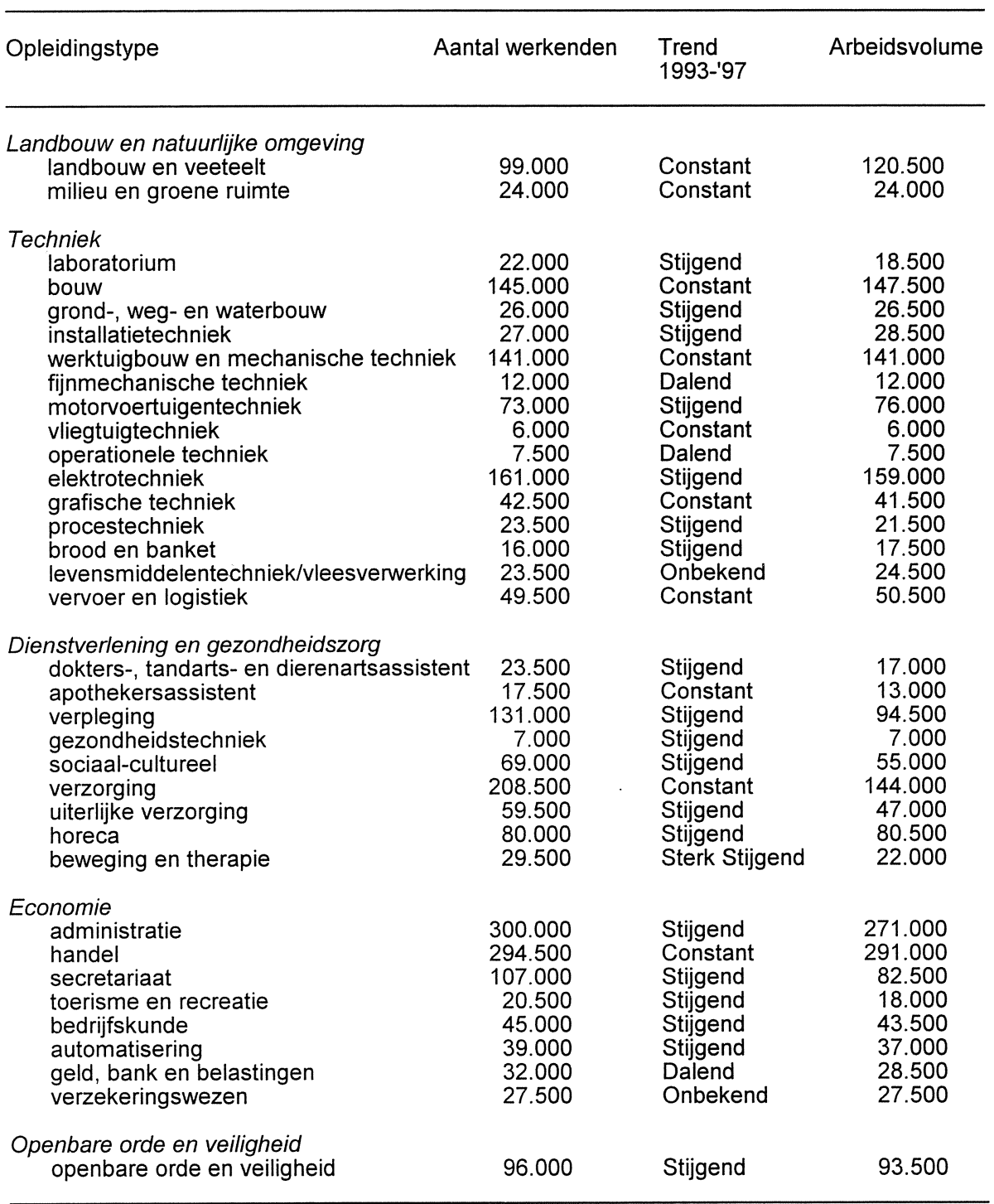

\section{Bron: CBS/ROA}

Toelichting: Het aantal werkenden heeft betrekking op iedereen die jonger is dan 65 en minstens 12 uur per week werkt. Arbeidsvolume is het totaal aantal normaal gewerkte arbeidsjaren gedeeld door 40 .

\subsection{Beschikbaarheid van bpv-plaatsen}

De beschikbaarheid van bpv-plaatsen hangt uiteraard sterk samen met de ontwikkelingen in de werkgelegenheid. Uit hoofdstuk 2 kwam reeds naar voren dat er in eerste instantie drie determinanten zijn die op middellange termijn deze beschikbaarheid van bpv-plaatsen bepalen. In de eerste plaats blijkt een aanzienlijk deel 
van leerplaatsen zeker op deze middellange termijn nauwelijks af te hangen van de specifieke werkgelegenheidsontwikkelingen. Bedrijven hebben afspraken binnen de branche of regio gemaakt of hebben een eigen beleid waarin het aantal leerplaatsen een vast gegeven is. In de tweede plaats komt een deel van de beschikbare bpvplaatsen voort uit korte-termijn overwegingen van bedrijven. Omdat men op dit moment behoefte heeft aan personeel om de gewenste productiviteit te bereiken worden ook bpv-plaatsen beschikbaar gesteld om zo ook leerlingen te kunnen werven. Deze component van de vraag is daarom sterk afhankelijk van de actuele werkgelegenheidsontwikkelingen bij de bedrijven. Ten derde komt echter een deel van de vraag naar leerlingen voort uit de behoefte van het bedrijf om zelf personeel op te leiden. Dit deel van de vraag komt dus voort uit de werk-gelegenheidsontwikkeling die men voor de toekomst voorziet.

Daarnaast vormen leerlingen ook een interessant substituut voor gekwalificeerde vakkrachten op het moment dat er schaarste ontstaat aan deze categorie personeel. Met name hierdoor blijkt in de praktijk de beschikbaarheid van bpv-plaatsen conjunctuurgevoelig te zijn.

Tabel 5.2 geeft een beeld van de verwachte ontwikkeling van het aantal leerplaatsen. Omdat het aantal leerplaatsen voor een deel gekoppeld is aan de werkgelegenheidsontwikkeling is in de tabel te zien dat de sectoren met de grootste verwachte uitbreidingsvraag ook de sterkste stijging van het aantal leerplaatsen valt waar te nemen. De opleidingen waarvoor de vraag zal dalen laten ook een daling van het aantal leerplaatsen zien.

Doordat werkgevers zich enerzijds laten leiden door gewoonte en anderzijds door de verwachte groei, groeit het aantal leerplaatsen altijd minder sterk dan de verwachte werkgelegenheidsgroei. Voor opleidingen waarbij er sprake is van een dalende werkgelegenheid, daalt het aantal leerplaatsen zelfs harder dan de werkgelegenheid. Hier speelt het effect dat bij een dalende werkgelegenheid het niet langer noodzakelijk is om leerlingen aan te nemen om in de toekomstige personeelsbehoefte te voorzien. Het aantal leerplaatsen daalt daarom sterker dan op grond van de uitbreidingsvraag verwacht mocht worden.

Als we de totale groei van bpv-plaatsen vertalen naar een vraag naar leerlingen, blijkt dat vraag en aanbod van BBL-leerlingen de komende jaren redelijk in evenwicht zullen zijn. De knelpunten op de markt voor bpv-plaatsen die zich de komende jaren zullen voordoen komen dan ook nauwelijks voort uit dergelijke discrepanties, maar hebben allereerst met name te maken met de huidige krapte op de arbeidsmarkt. Doordat het moeilijk is om aan personeel te komen, werven bedrijven ook nadrukkelijk onder leerlingen om daarmee in hun acute personeelsbehoefte te voorzien. Daarnaast tekent zich een tendens af dat steeds meer deelnemers aan de $\mathrm{BBL}$ werknemers zijn die reeds in dienst zijn van een bedrijf. Hoewel structureel gezien vraag en aanbod redelijk in evenwicht zijn, kan dit betekenen dat bedrijven die veel laag-gekwalificeerd personeel in huis hebben makkelijk de doorgroei kunnen maken naar hoger gekwalificeerd personeel, terwijl bedrijven die voor de invul- 
ling van bpv-plaatsen mensen moeten werven geen adequaat personeel kunnen vinden.

Tabel 5.2

Aantal BPV-plaatsen in 1999 en 2004

\begin{tabular}{|c|c|c|c|}
\hline Opleidingstype & \multicolumn{2}{|c|}{ Aantal BPV-plaatsen } & $\begin{array}{c}\text { groei '99-'04 } \\
\%\end{array}$ \\
\hline \multicolumn{4}{|l|}{ Landbouw en natuurlijke omgeving } \\
\hline landbouw en veeteelt & 4.200 & 4.400 & 4 \\
\hline milieu en groene ruimte & 2.300 & 2.500 & 7 \\
\hline \multicolumn{4}{|l|}{ Techniek } \\
\hline laboratorium & - & - & - \\
\hline bouw & 14.300 & 14.600 & 2 \\
\hline grond-, weg-en waterbouw & 900 & 900 & -0 \\
\hline installatietechniek & 5.800 & 5.800 & -0 \\
\hline werktuigbouw en mechanische techniek & 15.800 & 15.300 & -3 \\
\hline fijnmechanische techniek & 500 & 500 & 2 \\
\hline motorvoertuigentechniek & 2.200 & 2.200 & 1 \\
\hline vliegtuigtechniek & - & - & - \\
\hline operationele techniek & 500 & 500 & 5 \\
\hline elektrotechniek & 3.800 & 3.900 & 1 \\
\hline grafische techniek & 1.200 & 1.100 & -7 \\
\hline procestechniek & 1.400 & 1.500 & 6 \\
\hline brood en banket & 1.200 & 1.200 & -3 \\
\hline levensmiddelentechniek/vleesverwerking & 1.600 & 1.600 & 2 \\
\hline vervoer & 1.700 & 1.800 & 6 \\
\hline \multicolumn{4}{|l|}{ Dienstverlening en gezondheidszorg } \\
\hline dokters-, tandarts- en dierenartsassistent & 2.300 & 2.500 & 10 \\
\hline apothekersassistent & 3.200 & 3.700 & 15 \\
\hline verpleging & 5.500 & 5.900 & 8 \\
\hline gezondheidstechniek & & - & - \\
\hline sociaal-cultureel & 2.900 & 3.100 & 7 \\
\hline verzorging & 3.500 & 3.500 & -0 \\
\hline uiterlijke verzorging & 9.000 & 9.300 & 4 \\
\hline horeca & 8.300 & 9.100 & 10 \\
\hline beweging en therapie & 3.700 & 3.800 & 2 \\
\hline \multicolumn{4}{|l|}{ Economie } \\
\hline administratie & 7.300 & 7.600 & 5 \\
\hline handel & 6.200 & 6.300 & 2 \\
\hline secretariaat & 5.400 & 5.700 & 7 \\
\hline toerisme en recreatie & - & - & - \\
\hline bedrijfskunde & - & - & - \\
\hline automatisering & - & - & - \\
\hline geld, bank en belastingen & - & - & - \\
\hline verzekeringswezen & - & - & - \\
\hline \multicolumn{4}{|l|}{ openbare orde en veiligheid } \\
\hline openbare orde en veiligheid & - & - & - \\
\hline Totaal & 127.200 & 132.200 & 4 \\
\hline
\end{tabular}

Bron: ROA 


\subsection{Prognoses voor de vraag naar onderwijsverlaters van de BOL en de BBL}

Als eerste worden in deze paragraaf prognoses getoond voor de vraag naar onderwijsverlaters uit de BOL en de BBL. Hierbij wordt aansluiting gezocht bij de prognoses zoals deze in het kader van De Arbeidsmarkt naar Opleiding en Beroep tot 2004 gemaakt zijn. Deze prognoses zijn in eerste instantie gemaakt per opleidingsrichting, en niet verbijzonderd naar de gevolgde leerweg.

\section{De vraag naar afgestudeerden}

De totale vraag naar schoolverlaters kan worden onderscheiden in twee componenten, de vervangings- en de uitbreidingsvraag. Indien deze twee componenten worden gesommeerd resulteert het aantal baanopeningen. De definitie van baanopeningen luidt als volgt (ROA, 1999): De totale vraag naar nieuwkomers op de arbeidsmarkt, zoals deze is bepaald door de werkgelegenheidsgroei (positieve uitbreidingsvraag) en de vervangingsvraag.

De vervangingsvraag is de vraag naar nieuwe arbeidskrachten die ontstaat doordat de arbeidsplaatsen van werkenden die met pensioen gaan, arbeidsongeschikt worden of zich (tijdelijk) terugtrekken van de arbeidsmarkt, opnieuw moeten worden opgevuld. Vertrek van werkenden dat niet leidt tot vraag naar nieuwkomers uit hetzelfde opleidingstype of beroepsklasse wordt niet meegerekend als vervangingsvraag. De gemiddelde jaarlijkse vervangingsbehoefte als percentage van het totaal aantal werkenden is voor de periode $1999-20043,4 \%$. Dit is een daling ten opzichte van de gemiddelde vervangingsvraagprognose voor de periode 1997-2002, toen bedroeg dit percentage nog $3,7 \%$. De gemiddelde jaarlijkse vervangingsbehoefte op het niveau van het secundair beroepsonderwijs bedraagt circa $3,2 \%$, en ligt dus iets onder het gemiddelde totaalniveau.

Tabel 5.3 geeft een beeld van de vervangingsvraag bij het secundair beroepsonderwijs. Het blijkt dat vooral in de clusters techniek en dienstverlening en gezondheidszorg de komende vijf jaar de vervangingsbehoefte relatief hoog zal zijn. Een relatief groot aantal werkenden met deze opleidingsachtergronden zal zich in die periode (tijdelijk) van de arbeidsmarkt terugtrekken.

De uitbreidingsvraag is de vraag naar nieuwe arbeidskrachten die ontstaat door groei van de werkgelegenheid.

Als er sprake is van een werkgelegenheidsdaling is de uitbreidingsvraag negatief. De uitbreidingsvraag staat in tabel 5.4.

De som van uitbreidingsvraag en vervangingsvraag resulteert in het aantal baanopeningen per opleidingstype. Deze staan gepresenteerd in tabel 5.5 . 
Tabel 5.3

Verwachte vervangingsvraag per opleidingstype, 1999-2004

\begin{tabular}{|c|c|c|c|c|}
\hline Opleidingstype & Aantal & $\begin{array}{r}\text { totaal } \\
\%\end{array}$ & $\begin{array}{l}\text { gemiddeld } \\
\text { jaarlijks \% }\end{array}$ & typering \\
\hline \multicolumn{5}{|l|}{ Landbouw en natuurlijke omgeving } \\
\hline $\begin{array}{l}\text { landbouw en veeteelt } \\
\text { milieu en groene ruimte }\end{array}$ & $\begin{array}{r}19.700 \\
2.400\end{array}$ & $\begin{array}{l}21 \\
11\end{array}$ & $\begin{array}{l}3,9 \\
2,1\end{array}$ & $\begin{array}{l}\text { Gemiddeld } \\
\text { Laag }\end{array}$ \\
\hline \multicolumn{5}{|l|}{ Techniek } \\
\hline laboratorium & 4.200 & 20 & 3,7 & Gemiddeld \\
\hline bouw & 21.500 & 14 & 2,7 & Laag \\
\hline grond-, weg-en waterbouw & 3.000 & 12 & 2,3 & Laag \\
\hline installatietechniek & 3.900 & 13 & 2,5 & Laag \\
\hline $\begin{array}{l}\text { werktuigbouw en mechanische } \\
\text { techniek }\end{array}$ & 32.600 & 23 & 4,2 & $\mathrm{Hoog}$ \\
\hline fijnmechanische techniek & 2.500 & 18 & 3,3 & Gemiddeld \\
\hline motorvoertuigentechniek & 11.200 & 15 & 2,8 & Laag \\
\hline vliegtuigtechniek & 1.400 & 24 & 4,5 & Hoog \\
\hline operationele techniek & 1.100 & 16 & 2,9 & Gemiddeld \\
\hline elektrotechniek & 25.100 & 14 & 2,7 & Laag \\
\hline grafische techniek & 9.800 & 23 & 4,3 & Hoog \\
\hline procestechniek & 2.300 & 9 & 1,8 & Erg Laag \\
\hline $\begin{array}{l}\text { brood en banket } \\
\text { levensmiddelentechniek/ }\end{array}$ & 2.800 & 15 & 2,9 & Laag \\
\hline vleesverwerking & 4.400 & 18 & 3,4 & Gemiddeld \\
\hline vervoer en logistiek & 9.000 & 17 & 3,2 & Gemiddeld \\
\hline \multicolumn{5}{|c|}{ Dienstverlening en gezondheidszorg } \\
\hline $\begin{array}{l}\text { dokters-, tandarts- en } \\
\text { dierenartsassistent }\end{array}$ & & & & \\
\hline dierenartsassistent & 3.000 & 14 & 2,6 & Laag \\
\hline apothekersassistent & 4.800 & 28 & 5,1 & Erg Hoog \\
\hline verpleging & 20.400 & 16 & 2,9 & Gemiddeld \\
\hline gezondheidstechniek & - & - & - & - \\
\hline sociaal-cultureel & 10.000 & 15 & 2,9 & Laag \\
\hline verzorging & 34.200 & 16 & 3,0 & Gemiddeld \\
\hline uiterlijke verzorging & 11.200 & 18 & 3,3 & Gemiddeld \\
\hline horeca & 10.700 & 13 & 2,5 & Laag \\
\hline beweging en therapie & 7.100 & 23 & 4,2 & Hoog \\
\hline \multicolumn{5}{|l|}{ Economie } \\
\hline administratie & 50.000 & 16 & 2,9 & Gemiddeld \\
\hline handel & 56.800 & 18 & 3,4 & Gemiddeld \\
\hline secretariaat & 18.100 & 17 & 3,1 & Gemiddeld \\
\hline toerisme en recreatie & 1.500 & 8 & 1,6 & Erg Laag \\
\hline bedrijfskunde & - & - & - & - \\
\hline automatisering & - & - & - & - \\
\hline geld, bank en belastingen & - & - & - & - \\
\hline verzekeringswezen & - & - & - & - \\
\hline \multicolumn{5}{|l|}{ Openbare orde en veiligheid } \\
\hline openbare orde en veiligheid & 16.000 & 16 & 3,0 & Gemiddeld \\
\hline
\end{tabular}

Bron: ROA 
Tabel 5.4

Verwachte uitbreidingsvraag per opleidingstype, 1999-2004

\begin{tabular}{|c|c|c|c|c|}
\hline Opleidingstype & Aantal & $\begin{array}{r}\text { totaal } \\
\%\end{array}$ & $\begin{array}{l}\text { gemiddeld } \\
\text { jaarlijks \% }\end{array}$ & typering \\
\hline \multicolumn{5}{|c|}{ Landbouw en natuurlijke omgeving } \\
\hline $\begin{array}{l}\text { landbouw en veeteelt } \\
\text { milieu en groene ruimte }\end{array}$ & $\begin{array}{r}11.600 \\
4.100\end{array}$ & $\begin{array}{l}13 \\
19\end{array}$ & $\begin{array}{l}2,4 \\
3,5\end{array}$ & $\begin{array}{l}\text { Gemiddeld } \\
\text { Gemiddeld }\end{array}$ \\
\hline \multicolumn{5}{|l|}{ Techniek } \\
\hline laboratorium & 900 & 4 & 0,8 & Gemiddeld \\
\hline bouw & 10.600 & 7 & 1,4 & Gemiddeld \\
\hline grond-, weg-en waterbouw & -100 & 0 & $-0,1$ & Laag \\
\hline installatietechniek & -100 & 0 & $-0,1$ & Laag \\
\hline \multicolumn{5}{|l|}{ werktuigbouw en } \\
\hline mechanische techniek & -10.300 & -7 & $-1,5$ & Laag \\
\hline fijnmechanische techniek & -800 & -6 & $-1,2$ & Laag \\
\hline motorvoertuigentechniek & 2.300 & 3 & 0,6 & Gemiddeld \\
\hline vliegtuigtechniek & -700 & -12 & $-2,4$ & Laag \\
\hline operationele techniek & 900 & 12 & 2,3 & Gemiddeld \\
\hline elektrotechniek & 3.300 & 2 & 0,4 & Gemiddeld \\
\hline grafische techniek & -6.300 & $-1 \overline{5}$ & $-3,2$ & Erg Laag \\
\hline procestechniek & 3.500 & 14 & 2,7 & Gemiddeld \\
\hline $\begin{array}{l}\text { brood en banket } \\
\text { levensmiddelentechniek/ }\end{array}$ & -2.800 & -15 & $-3,3$ & Erg Laag \\
\hline vleesverwerking & 1.000 & 4 & 0,8 & Gemiddeld \\
\hline vervoer en logistiek & 7.700 & 15 & 2,8 & Gemiddeld \\
\hline \multicolumn{5}{|c|}{ Dienstverlening en gezondheidszorg } \\
\hline $\begin{array}{l}\text { dokters-, tandarts- en } \\
\text { dierenartsassistent }\end{array}$ & & & & \\
\hline $\begin{array}{l}\text { dierenartsassistent } \\
\text { apothekersassistent }\end{array}$ & & $\begin{array}{l}16 \\
26\end{array}$ & $\begin{array}{l}3,1 \\
48\end{array}$ & Gemiddeld \\
\hline $\begin{array}{l}\text { apothekersassistent } \\
\text { verpleging }\end{array}$ & $\begin{array}{r}4.500 \\
17.500\end{array}$ & & $\begin{array}{l}4,8 \\
2,5\end{array}$ & Gemiddeld \\
\hline gezondheidstechniek & - & - & - & - \\
\hline sociaal-cultureel & 14.600 & 23 & 4,2 & Hoog \\
\hline verzorging & -800 & 0 & $-0,1$ & Laag \\
\hline uiterlijke verzorging & 9.500 & 15 & 2,8 & Gemiddeld \\
\hline horeca & 16.200 & 20 & 3,7 & Hoog \\
\hline beweging en therapie & 2.500 & 8 & 1,6 & Gemiddeld \\
\hline \multicolumn{5}{|l|}{ Economie } \\
\hline administratie & 52.500 & 16 & 3,1 & Gemiddeld \\
\hline handel & 13.900 & 4 & 0,9 & Gemiddeld \\
\hline secretariaat & 25.600 & 24 & 4,3 & Hoog \\
\hline toerisme en recreatie & 5.100 & 27 & 5,0 & Hoog \\
\hline bedrijfskunde & - & - & - & - \\
\hline automatisering & - & - & - & - \\
\hline geld, bank en belastingen & - & - & - & - \\
\hline verzekeringswezen & - & - & - & - \\
\hline \multicolumn{5}{|l|}{ Openbare orde en veiligheid } \\
\hline openbare orde en veiligheid & 1.200 & 1 & 0,2 & Gemiddeld \\
\hline
\end{tabular}

Bron: ROA 
Tabel 5.5

Verwachte baanopeningen per opleidingstype, 1999-2004

\begin{tabular}{|c|c|c|c|c|}
\hline Opleidingstype & Aantal & $\begin{array}{r}\text { totaal } \\
\%\end{array}$ & $\begin{array}{l}\text { gemiddeld } \\
\text { jaarlijks \% }\end{array}$ & typering \\
\hline \multicolumn{5}{|c|}{ Landbouw en natuurlijke omgeving } \\
\hline $\begin{array}{l}\text { landbouw en veeteelt } \\
\text { milieu en groene ruimte }\end{array}$ & $\begin{array}{r}31.300 \\
6.500\end{array}$ & $\begin{array}{l}34 \\
30\end{array}$ & $\begin{array}{l}6,3 \\
5,6\end{array}$ & $\begin{array}{l}\text { Gemiddeld } \\
\text { Gemiddeld }\end{array}$ \\
\hline \multicolumn{5}{|l|}{ Techniek } \\
\hline laboratorium & 5.100 & 24 & 4,5 & Gemiddeld \\
\hline bouw & 32.100 & 21 & 4,1 & Gemiddeld \\
\hline grond-, weg-en waterbouw & 3.000 & 12 & 2,3 & Laag \\
\hline installatietechniek & 3.900 & 13 & 2,5 & Laag \\
\hline \multicolumn{5}{|l|}{ werktuigbouw en } \\
\hline mechanische techniek & 32.600 & 23 & 4,2 & Gemiddeld \\
\hline fijnmechanische techniek & 2.500 & 18 & 3,3 & Gemiddeld \\
\hline motorvoertuigentechniek & 13.500 & 18 & 3,4 & Gemiddeld \\
\hline vliegtuigtechniek & 1.400 & 24 & 4,5 & Gemiddeld \\
\hline operationele techniek & 2.000 & 28 & 5,2 & Gemiddeld \\
\hline elektrotechniek & 28.400 & 16 & 3,1 & Gemiddeld \\
\hline grafische techniek & 9.800 & 23 & 4,3 & Gemiddeld \\
\hline procestechniek & 5.800 & 23 & 4,5 & Gemiddeld \\
\hline $\begin{array}{l}\text { brood en banket } \\
\text { levensmiddelentechniek/ }\end{array}$ & 2.800 & 15 & 2,9 & Laag \\
\hline vleesverwerking & 5.400 & 22 & 4,2 & Gemiddeld \\
\hline vervoer en logistiek & 16.700 & 32 & 6,0 & Gemiddeld \\
\hline \multicolumn{5}{|c|}{ Dienstverlening en gezondheidszorg } \\
\hline dokters-, tandarts- en & & & & \\
\hline dierenartsassistent & 6.600 & 30 & 5,7 & Gemiddeld \\
\hline apothekersassistent & 9.300 & 54 & 9,9 & Hoog \\
\hline verpleging & 37.900 & 29 & 5,4 & Gemiddeld \\
\hline gezondheidstechniek & - & - & - & - \\
\hline sociaal-cultureel & 24.600 & 38 & 7,1 & Gemiddeld \\
\hline verzorging & 34.200 & 16 & 3,0 & Gemiddeld \\
\hline uiterlijke verzorging & 20.700 & 33 & 6,1 & Gemiddeld \\
\hline horeca & 26.900 & 33 & 6,2 & Gemiddeld \\
\hline beweging en therapie & 9.600 & 31 & 5,8 & Gemiddeld \\
\hline \multicolumn{5}{|l|}{ Economie } \\
\hline administratie & 102.500 & 32 & 6,0 & Gemiddeld \\
\hline handel & 70.700 & 22 & 4,3 & Gemiddeld \\
\hline secretariaat & 43.700 & 41 & 7,4 & Hoog \\
\hline toerisme en recreatie & 6.600 & 35 & 6,6 & Gemiddeld \\
\hline bedrijfskunde & - & - & - & - \\
\hline automatisering & - & - & - & - \\
\hline geld, bank en belastingen & - & - & - & - \\
\hline verzekeringswezen & - & - & - & - \\
\hline \multicolumn{5}{|l|}{ Openbare orde en veiligheid } \\
\hline openbare orde en veiligheid & 17.200 & 17 & 3,2 & Gemiddeld \\
\hline
\end{tabular}

Bron: ROA

\subsection{Perspectieven voor BOL en BBL}

Tabel 5.6 geeft een beeld van de arbeidsmarktperspectieven voor de onderscheiden secundaire beroepsopleidingen. Het perspectief van de opleiding wordt aangegeven met de ITA: Indicator Toekomstig Arbeidsmarktperspectief. Als het aanbod groter is dan de vraag is de ITA groter dan 1, en kent de opleiding slechts een redelijk, matig 
of slecht perspectief. Als er meer vraag is dan aanbod is de ITA juist lager dan 1 en is het perspectief (zeer) goed.

BOL en BBL zijn uiteraard sterke substituten op de arbeidsmarkt. Zoals uit de resultaten uit hoofdstuk 2 naar voren kwam hebben sommige werkgevers echter een voorkeur voor BBL-gediplomeerden, terwijl anderen een voorkeur hebben voor schoolverlaters uit de BOL. De vraag naar nieuwkomers met een kwalificatie op het niveau van het secundair beroepsonderwijs is dus op te splitsen in drie domeinen: vraag die in eerste instantie gericht is op de BBL (BBL-domein), vraag die gericht is op de BOL (BOL-domein) en een gemeenschappelijk domein.

Op grond van de resultaten van de werkgeversenquête is per opleidingstype de omvang van het domein vastgesteld. Op basis van deze domeinen is het mogelijk om de perspectieven voor BOL en BBL afzonderlijk vast te stellen. Als bijvoorbeeld het BBL-domein in vergelijking met het aanbod groot is en het BOL-domein klein, dan zullen de perspectieven van de BBL beter zijn. Naarmate het gezamenlijk domein groter is, zal de gevolgde leerweg minder relevant zijn en zullen de perspectieven daardoor dichter bij elkaar liggen.

Bij alle opleidingstypen blijkt het gezamenlijk domein het grootst te zijn. Doorgaans is daarnaast de specifieke vraag naar onderwijsverlaters van de BBL groter dan de vraag naar BOL'ers. Uitzonderingen daarop zijn bijvoorbeeld motorvoertuigentechniek en verzorging. Omdat het aanbod vanuit de BBL doorgaans kleiner is dan van de $\mathrm{BOL}$, blijken de perspectieven voor de BBL voor alle richtingen gunstiger te zijn dan voor de BOL. In tabel 5.6 staat voor alle opleidingen in het secundair beroepsonderwijs de perspectieven uitgesplitst naar de BOL- en de BBL-variant. In een aantal gevallen bleek het om statistische redenen niet goed mogelijk een perspectief te bepalen voor de BBL-variant, in die gevallen is volstaan met het perspectief voor de BOL-variant.

Vanwege de bovengeschetste vraag- en aanbodverschillen blijken de perspectieven voor de BBL doorgaans beter. De verschillen zijn echter in de meeste gevallen klein. Het verschil in perspectief is met name opmerkelijk groot bij administratie en secretariaat. Verder is er ook een groot verschil bij operationele techniek, elektrotechniek en grafische techniek, apothekersassistent, verzorging, horeca en handel. Vooral voor de richtingen elektrotechniek, sociaal-cultureel, verzorging en horeca zijn de verschillen relevant, omdat voor deze richting een goed of zelfs zeer goed perspectief voor de BBL-gediplomeerden bestaat, terwijl er slechts een matig perspectief voor de BOL-gediplomeerden is. 
Tabel 5.6

Prognoses voor de perspectieven van de BBL en BOL

\begin{tabular}{|c|c|c|c|c|}
\hline \multirow[t]{2}{*}{ Opleidingsrichting } & \multicolumn{2}{|c|}{ BBL } & \multicolumn{2}{|c|}{$\mathrm{BOL}$} \\
\hline & ITA & Typering & ITA & Typering \\
\hline \multicolumn{5}{|l|}{ Landbouw en natuurlijke omgeving } \\
\hline $\begin{array}{l}\text { landbouw en veeteelt } \\
\text { milieu en groene ruimte }\end{array}$ & $\begin{array}{l}0,91 \\
1,11\end{array}$ & $\begin{array}{l}\text { Goed } \\
\text { Matig }\end{array}$ & $\begin{array}{l}0,94 \\
1,13\end{array}$ & $\begin{array}{l}\text { Goed } \\
\text { Matig }\end{array}$ \\
\hline \multicolumn{5}{|l|}{ Techniek } \\
\hline laboratorium & - & - & 1,05 & Redelijk \\
\hline bouw & 1,17 & Slecht & 1,19 & Slecht \\
\hline grond-, weg-en waterbouw & 1,28 & Slecht & 1,28 & Slecht \\
\hline $\begin{array}{l}\text { installatietechniek } \\
\text { werktuigbouw en }\end{array}$ & 1,38 & Slecht & 1,39 & Slecht \\
\hline mechanische techniek & 1,14 & Matig & 1,15 & Matig \\
\hline $\begin{array}{l}\text { fijnmechanische techniek } \\
\text { motorvoertuigentechniek }\end{array}$ & $\begin{array}{l}1,04 \\
1,09\end{array}$ & $\begin{array}{l}\text { Redelijk } \\
\text { Matig }\end{array}$ & $\begin{array}{l}1,06 \\
1,10\end{array}$ & $\begin{array}{l}\text { Matig } \\
\text { Matig }\end{array}$ \\
\hline vliegtuigtechniek & & & 0,95 & Goed \\
\hline operationele techniek & 1,19 & Slecht & 1,26 & Slecht \\
\hline elektrotechniek & 0,99 & Goed & 1,10 & Matig \\
\hline grafische techniek & 1,02 & Redelijk & 1,09 & Matig \\
\hline $\begin{array}{l}\text { procestechniek } \\
\text { brood en banket }\end{array}$ & 0,99 & Goed & 1,00 & Goed \\
\hline $\begin{array}{l}\text { brood en banket } \\
\text { levensmiddelentechniek/ }\end{array}$ & 1,14 & Matig & 1,18 & Slecht \\
\hline $\begin{array}{l}\text { vleesverwerking } \\
\text { vervoer en logistiek }\end{array}$ & $\begin{array}{l}1,10 \\
0,92\end{array}$ & $\begin{array}{l}\text { Matig } \\
\text { Goed }\end{array}$ & $\begin{array}{l}1,11 \\
0,95\end{array}$ & $\begin{array}{l}\text { Matig } \\
\text { Goed }\end{array}$ \\
\hline \multicolumn{5}{|c|}{$\begin{array}{l}\text { Dienstverlening en Gezondheidszorg } \\
\text { dokters- tandarts- }\end{array}$} \\
\hline en dierenartsassistent & 1,06 & Matig & 1,15 & Matig \\
\hline apothekersassistent & 1,13 & Matig & 1,20 & Slecht \\
\hline verpleging & 0,82 & Zeer goed & 0,83 & Zeer goed \\
\hline gezondheidstechniek & 0,81 & Zeer goed & 0,78 & Zeer goed \\
\hline sociaal-cultureel & 0,77 & Zeer goed & 1,11 & Matig \\
\hline verzorging & 0,99 & Goed & 1,07 & Matig \\
\hline uiterlijke verzorging & 1,01 & Redelijk & 1,07 & Matig \\
\hline horeca & 0,97 & Goed & 1,07 & Matig \\
\hline bewegingen therapie & 1,01 & Redelijk & 1,10 & Matig \\
\hline \multicolumn{5}{|l|}{ Economie } \\
\hline $\begin{array}{l}\text { administratie } \\
\text { handel }\end{array}$ & $\begin{array}{l}0,67 \\
0,89\end{array}$ & $\begin{array}{l}\text { Zeer goed } \\
\text { Goed }\end{array}$ & $\begin{array}{l}1,00 \\
1,00\end{array}$ & $\begin{array}{l}\text { Goed } \\
\text { Goed }\end{array}$ \\
\hline secretariaat & 0,76 & Zeer goed & 0,99 & Goed \\
\hline toerisme en recreatie & - & - & 1,03 & Redelijk \\
\hline bedrijfskunde & - & - & - & - \\
\hline automatisering & - & - & - & - \\
\hline geld, bank en belastingen & - & - & - & - \\
\hline verzekeringswezen & - & - & - & - \\
\hline $\begin{array}{l}\text { Openbare orde en veiligheid } \\
\text { openbare orde en veilighe }\end{array}$ & & & & \\
\hline 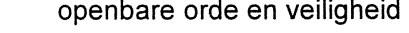 & - & - & 0,97 & Goed \\
\hline
\end{tabular}

De streepjes in de tabel zijn ingevoegd voor die opleidingstypen waarvoor geen betrouwbare prognoses gemaakt konden worden.

Bron: ROA 


\section{Conclusies}

De beroepsbegeleidende leerweg (BBL) is sterk aan de arbeidsmarkt gekoppeld doordat de instroom van leerlingen afhankelijk is van de beschikbaarheid van beroepspraktijkvormingsplaatsen. Deze afhankelijkheid kan zowel een positief als negatief effect hebben. Als het aanbod van beroepspraktijkvormingsplaatsen voornamelijk bepaald wordt door een toekomstige behoefte aan gekwalificeerd personeel, dan worden alleen die mensen opgeleid waaraan in ieder geval binnen het betreffende bedrijf in de toekomst behoefte is. Als daarentegen de huidige personeelsbehoefte met name bepalend is, dan bestaat het gevaar dat er mensen worden opgeleid waar in de toekomst onvoldoende vraag voor is. Voor zinvol beleid gericht op versterking van de $B B L$ is het daarom van groot belang om inzicht te krijgen in factoren die van invloed zijn op het aanbod van beroepspraktijkvormingsplaatsen.

In dit rapport is de markt voor de BBL nader geanalyseerd. Er is zowel gekeken naar vraag en aanbod van leerlingen voor de BBL als naar vraag en aanbod van gediplomeerden. De resultaten van deze analyses zijn vervolgens vertaald in prognoses voor vraag- en aanbod voor de BBL voor de periode 1999-2004. In dit hoofdstuk worden de belangrijkste conclusies nog eens op een rij gezet.

\section{De vraag naar BBL-leerlingen}

De meeste leerbedrijven leiden BBL-leerlingen op vanwege een toekomstige behoefte aan gekwalificeerd personeel. Daarnaast is ook de directe inzetbaarheid van BBL-leerlingen in het productieproces voor veel bedrijven een belangrijke motivatie voor het in dienst nemen van leerlingen. Er zijn hierin wel enkele duidelijke verschillen tussen bedrijfssectoren. In de horeca speelt de directe inzetbaarheid van leerlingen een veel grotere rol dan in de meeste andere bedrijfssectoren. In de zakelijke dienstverlening is de directe inzetbaarheid van leerlingen juist van veel minder belang.

Bijna tweederde van de leerbedrijven zegt dat BBL-leerlingen zich terugverdienen tijdens de aanstellingsperiode. Of leerlingen zich terugverdienen is in sterke mate afhankelijk van hun inzetbaarheid. In bedrijfssectoren waar de directe inzetbaarheid van leerlingen van groot belang is, zoals de horeca, verdienen leerlingen zich inderdaad ook vaak terug. In de zakelijk dienstverlening verdienen leerlingen zich meestal niet terug. De arbeidsproductiviteit van leerlingen is in deze sector ook erg laag.

Een kwart van de BBL-leerlingen heeft al tijdens de opleiding een vaste aanstelling bij het leerbedrijf. Dit betreft waarschijnlijk vooral leerlingen die al langere tijd bij het leerbedrijf werkzaam zijn en op eigen initiatief of op initiatief van het bedrijf alsnog een opleiding zijn gaan volgen. Met name in de handel en in de garagesector komen vaste aanstellingen erg vaak voor. In de zakelijke dienstverlening hebben leerlingen daarentegen vrijwel nooit een vaste aanstelling. De kans dat een BBL-leerling die 
nog geen vaste aanstelling heeft na afloop van de opleiding een vervolgaanstelling aangeboden krijgt is in alle sectoren, met uitzondering van de horeca, vrij hoog. Volgens de geënquêteerde bedrijven kan $74 \%$ van de leerlingen na afloop van de opleiding bij het leerbedrijf blijven werken. Deze kans hangt bovendien vooral af van de kwaliteit van de BBL-leerling en in veel mindere mate van de behoefte aan personeel op dat moment. De kans dat de BBL-leerling zelf bij het leerbedrijf wil blijven wordt door de meeste bedrijven hoog ingeschat, gemiddeld boven de $70 \%$. Uitzondering is weer de horeca, waar de kans veel lager wordt ingeschat.

Ook al vormen de huidige en toekomstige personeelsbehoefte een belangrijke motivatie om BBL-leerlingen in dienst te nemen, de meeste bedrijven passen het opleidingsbeleid niet direct aan als de behoefte aan personeel tijdelijk of structureel toeneemt. De reden hiervoor is waarschijnlijk dat het aannemen van extra leerlingen gepaard moet gaan met het vergroten van de opleidingscapaciteit. Het bedrijf moet bijvoorbeeld meer opleiders en begeleiders in dienst gaan nemen. Bovendien is de toekomstige groei moeilijk in te schatten. De toekomstige behoefte aan personeel als gevolg van natuurlijk verloop binnen het bedrijf is daarentegen veel beter in te schatten. Bedrijven hanteren daarom een vaste vuistregel voor het aantal BBLleerlingen en laten zich niet zo sterk beïnvloeden door de waan van de dag. Dit betekent wel dat de huidige vraag naar BBL-leerlingen achterblijft bij de toekomstige vraag naar gediplomeerden.

Voor veel bedrijven die nu geen BBL-leerlingen in dienst hebben zou het wel kunnen lonen toch leerlingen in dienst te nemen. De meeste van de niet-leerbedrijven $(60 \%)$ verwacht bijvoorbeeld de kosten van een leerling nog tijdens de leeraanstelling terug te kunnen verdienen. De belangrijkste belemmering is echter de beschikbaarheid van BBL-leerlingen. Daarnaast vinden veel bedrijven de kans dat de leerling na afloop van de opleiding vertrekt te groot. Dit is voornamelijk een probleem voor bedrijven die leerlingen zouden willen opleiden vanwege een toekomstige behoefte aan gekwalificeerd personeel.

Overigens komen uit de prognoses vooralsnog geen sterke discrepanties tussen het aanbod van leerlingen en de beschikbaarheid van bpv-plaatsen naar voren. Bij een aanzienlijk deel van de leerlingen gaat het echter om werknemers die al enige tijd in dienst zijn van een bedrijf en vanuit een normale arbeidsrelatie een BLL-opleiding gaan volgen. De problemen om leerlingen te krijgen doen zich dan ook waarschijnlijk vooral voor bij bedrijven die extern leerlingen willen werven. Gezien de huidige krapte op de arbeidsmarkt kan het moeilijk zijn mensen te werven voor bpv-plaatsen die alleen een stagevergoeding of een bescheiden salaris kennen. Voor veel potentiële leerlingen biedt de huidige arbeidsmarkt immers financieel aantrekkelijke alternatieven buiten de BBL. Door te profiteren van de huidige gunstige situatie op de arbeidsmarkt, investeren zij echter mogelijk te weinig in hun kwalificaties, waardoor zij later, als er economisch gezien mindere tijden aan zouden breken, in een moeilijke positie terecht kunnen komen. 
De vraag naar gediplomeerden van de $B B L$

Zoals gezegd zijn beide leerwegen in het middelbaar beroepsonderwijs formeel gelijkwaardig. De eindtermen zijn immers voor beide leerwegen gelijk. Aangezien voor werkgevers echter ook aspecten mee kunnen wegen die niet tot uitdrukking komen in de formele eindtermen kan de arbeidsmarktpositie van beide groepen echter toch verschillen. Voor de hand ligt dat met name de werkervaring van BBLgediplomeerden versus de betere theoretische achtergrond van BOL-gediplomeerden hierbij een rol kunnen spelen.

Onderzocht is daarom in welke mate werkgevers de voorkeur hebben voor gediplomeerden van de BBL of de BOL. Het blijkt dat in de meeste bedrijfssectoren de BBL beter scoort dan de BOL. Volgens veel werkgevers zijn gediplomeerden van de BBL betere vakkrachten, lossen ze sneller nieuwe en onverwachte problemen op, zijn ze flexibeler en sneller ingewerkt. Op het gebied van nascholing en het vermogen om nieuwe dingen bij te leren scoren BBL-gediplomeerden niet beter dan BOLgediplomeerden. De beoordeling van BBL- en BOL-gediplomeerden verschilt wel tussen bedrijfssectoren. In de zakelijke dienstverlening scoort de BBL minder hoog dan in de overige sectoren. Overigens scoren BBL- en BOL-gediplomeerden in meer dan een kwart van de bedrijven gelijk. In de zakelijke dienstverlening is dat zelfs $40 \%$.

De gevolgde leerweg is echter niet het belangrijkste selectiecriterium voor bedrijven. Driekwart van de bedrijven zegt dat de uiteindelijke voorkeur sterk afhankelijk is van de persoon. Blijkbaar is de variatie tussen kandidaten die een bepaalde leerweg hebben gevolgd zo groot dat de gevolgde leerweg alleen een te mager selectiecriterium is. Uit een nadere analyse van het selectiegedrag van werkgevers in garagebedrijven en in de zorgsector blijkt dat vooral zaken als leeftijd, werkervaring, eindcijfers voor vakspecifieke studie-onderdelen een belangrijke rol spelen bij personeelsselectie. Daarnaast is bijvoorbeeld ook de hobby van kandidaten voor veel werkgevers van belang.

Gegeven de informatie die beschikbaar is, is het thans nog moeilijk om na te gaan wat de betekenis van de verschillende niveaus binnen het middelbaar beroepsonderwijs in dit opzicht is. Het zou zo kunnen zijn dat de gunstige positie van de BBL met name voor de lagere opleidingsniveaus geldt, daar de BBL bij deze opleidingen het sterkst vertegenwoordigd is. Bij opleidingen op niveau 4 zou de situatie wel eens omgekeerd kunnen zijn. Veel opleidingen op een hoger niveau zijn echter pas vrij recent via de $B B L$ te volgen. Werkgevers hebben daarom nog minder ervaringen met de BBL voor opleidingen op dit niveau. Daarnaast is een aantal beschikbare databronnen nog onvoldoende toegesneden op de nieuwe structuur. Het is daarom nog te vroeg om te onderzoeken of de voorkeuren van werkgevers sterk verband houden met het vereiste opleidingsniveau.

Uit de arbeidsmarktprognoses voor gediplomeerden van het secundaire beroepsonderwijs komt naar voren dat de arbeidsmarktperspectieven voor de verschillende 
richtingen in de BBL thans doorgaans gunstiger zijn dan voor de BOL. Dit is zeker niet altijd het geval geweest en lijkt dus vooral een uiting van de huidige economische situatie. Momenteel lijkt er vanuit arbeidsmarktperspectief echter duidelijk ruimte voor een uitbreiding van de BBL, met name in opleidingsrichtingen met goede of zeer goede perspectieven. Ook hier speelt echter mogelijk dat de sterke vraag naar BBL'ers deels ook een weerspiegeling is van de sterke behoefte aan personeel dat snel inzetbaar en productief is. De voordelen van gediplomeerden uit de BOL, die veelal een groter leer- en aanpassingsvermogen hebben, raken door de huidige schaarste op de arbeidsmarkt wellicht ondergesneeuwd.

Geconcludeerd kan worden dat de positie van de BBL momenteel erg sterk is. In de meeste sectoren zijn voldoende beroepspraktijkvormingsplaatsen en de grootste belemmeringen lijken voort te komen uit een tekort aan leerlingen. Hoewel vraag en aanbod van leerlingen structureel gezien in evenwicht lijken te zijn, vormen mensen die reeds werken een steeds groter deel van de deelnemers aan de BBL. Voor bedrijven die voor de vervulling van bpv-plaatsen afhankelijk zijn van de instroom van jongeren kan daardoor - zeker bij de huidige personeelstekorten op de arbeidsmarkt - een knelpunt ontstaan. Wel is het van groot belang dat de beschikbaarheid van beroepspraktijkvormingsplaatsen ook in de toekomst onder de aandacht blijft. Hoewel de meeste bedrijven opleiden vanwege een toekomstige behoefte aan personeel, reageren ze toch onvoldoende op verwachte werkgelegenheidsgroei in het bedrijf. Dit kan in de toekomst leiden tot een tekort aan beroepspraktijkvormingsplaatsen en daarmee tot een tekort aan gekwalificeerd personeel.

Het beeld dat in dit rapport naar voren komt, wordt uiteraard in hoge mate gekleurd door de actuele situatie op de arbeidsmarkt. Omdat de aansluiting van de BBL op het werk zeer groot is, is het juist voor deze leerweg van groot belang dat de ontwikkelingen op de arbeidsmarkt op de voet worden gevolgd. Door met enige regelmaat via een bedrijfsenquête en vignetonderzoek de positie van de BBL bij werkgevers te monitoren en door de prognoses van de arbeidsmarktontwikkelingen tijdig te vernieuwen, kan het beleid tijdig reageren op eventuele verschuivingen in thans zo gunstige positie van de BBL op de arbeidsmarkt. 


\section{Literatuur}

Acemoglu, D. en J.S. Pischke (1998), Why do firms train? Theory and evidence, Quarterly Journal of Economics, Vol. 113, no. 1, februari, pp. 79-119.

Acemoglu, D. en J.S. Pischke (1999), The Structure of Wages and Investment in General Training, Journal of Political Economy, Vol. 107, no. 3, juni, pp. 539-572.

Acemoglu, D. en J.S. Pischke (1999), Beyond Becker: Training in Imperfect Markets, Economic Journal, Vol. 109, no. 453, februari, pp. 112-142.

Beek, K.W.H. van (1993), To be hired or not to be hired, the employer decides: relative chances of unemployed job-seekers on the dutch labor market, proefschrift Universiteit van Amsterdam, Amsterdam.

Boerman, F.A. (1992), Het verdiende loon: een onderzoek naar opinies van werknemers over de rechtvaardigheid van individuele inkomens uit arbeid, proefschrift Rijksuniversiteit Utrecht, Utrecht: ISOR.

Borghans, L., A. Jacobs, W. Smits, J.D. Vlasblom, The Labour Market Position of apprenticeship versus school-based learning, ROA-RM-. . . I., verschijnt binnenkort.

Borghans, L., W. Smits (1996), Ontwikkelingen in het leerlingwezen tot 2000, ROAR-1996/6, Maastricht.

Chang, C. en Y. Wang (1996), Human Capital Investments under Asymmetric Information: The Pigovian Conjecture Revisited, Journal of Labor Economics, Vol. 14, no. 3, pp. 505-519.

Dekker, R.J.P., A. de Grip en J.A.M. Heijke (1990), An Explanation of the Occupational Structure of Sectors of industries, Labour, Vol. 4, no. 3, pp. 3-31.

Franz, W. en D. Soskice (1995), The German Apprenticeship System, in F. Buttler, W. Franz, R. Shettkat, D. Soskice (eds), Institutional Frameworks and Labor Market Performance, London and New York: Routledge, pp. 208-234.

Grip, A. de, J.A.M. Heijke en B.J.H. Lodder (1992), De invloed van vraagfactoren op de markt voor leerovereenkomsten, ROA-RM-1992/3, Maastricht.

Grip, A. de, H. Berendsen, L. Borghans en R.J.P. Dekker (1992), Toekomstverkenning leerlingwezen, ROA-R-1993/4, Maastricht.

Grip, A. de, H. Berendsen, L. Borghans en R.J.P. Dekker (1992), Forecasting flows into and out of apprenticeship training: a scenario approach, ROA-RM-1994/2, Maastricht.

Hermkens, P.L.J. (1983), Oordelen over rechtvaardigheid van inkomens: verslag van een vignetonderzoek, proefschrift Rijksuniversiteit Utrecht, Amsterdam: Kobra.

Houtman, D. (1994), Werkloosheid en sociale rechtvaardigheid: oordelen over de rechten en plichten van werklozen, proefschrift Erasmus Universiteit Rotterdam, Amsterdam: Boom.

Hövels, B.W.M. (1985), Arbeidsorganisaties en het leerlingwezen. Een onderzoek naar het aanbod van leer-arbeidsplaatsen door arbeidsorganisaties, Ministerie van Sociale Zaken en Werkgelegenheid, Den Haag. 
Katz, E. en A. Ziderman (1990), Investment in General Training: The Role of Information and Labour Mobility, Economic Journal, Vol. 100, no. 403, december, pp. 1147-1158.

Lieshout, H. van (1996), Beroepsonderwijs in Duitsland, Amsterdam: Max Goote Kenniscentrum voor beroepsonderwijs en volwasseneneducatie.

Lodder, B.J.H., A. de Grip en J.A.M. Heijke (1992), In- en uitstroom op de markt voor leerovereenkomsten, ROA-RM-1992/1, Maastricht.

Meerling (1987), Methoden en technieken van psychologisch onderzoek, deel 1, Meppel: Boom.

Ministerie van Sociale Zaken en Werkgelegenheid (1985), Educatie in CAO's, Den Haag.

Nijhof, W. (1998), Curriculum Characteristics and Labour Market Perspectives, in J.A.M. Heijke and L. Borghans (eds), Towards a Transparent Labour Market for Educational Decisions, pp. 197-222, Aldershot, Ashgate.

ROA (1997a), De Arbeidsmarkt naar Opleiding en Beroep tot 2002, ROA-R-1997/7, Maastricht.

ROA (1997b), De Arbeidsmarkt naar Opleiding en Beroep tot 2002, Actualisering Statistische Bijlage, ROA-R-1998/9b, Maastricht.

ROA (1999a), De Arbeidsmarkt naar Opleiding en Beroep tot 2004, ROA-R-1999/8, Maastricht.

ROA (1999b), De Arbeidsmarkt naar Opleiding en Beroep tot 2004, Statistische Bijlage, ROA-R-1999/8b, Maastricht.

Sar L. van der en B.M.S. van Praag (1993), The Evaluation Question Approach: A method of measuring attitudes, Journal of Economic Psychology, 14, NoordHolland, pp. 183-201.

Sinderman, P.M. en D.B. Grob (1996), Innovations in experimental design in attitude surveys, Annual Review of Sociology, 22, pp. 377-399.

Smits, W. (1999), Schoolverlaters van de BBL 1997, ROA-R-1999/6, Maastricht.

Smoorenburg, M.S.M. van en R.K.W. van der Velden (1995), Werken en leren in het leerlingwezen - de positie van het BBO: schooljaar 1992-1993, LDC, Leeuwarden.

Stevens, M. (1994), A Theoretical Model of On-the-Job Training with Imperfect Competition, Oxford Economic Papers, Vol. 46, no. 4, pp. 537-562.

Stevens, M. (1996), Transferable Training and Poaching Externalities in A.L. Booth en D.J. Snower (eds), Acquiring Skills. Market failures, their Symptoms and Policy Responses, Cambridge: Cambridge University Press, pp. 19-40.

Swanborn, P.G. (1982a), Operationaliseren en meten, in: P.G. Swanborn en L. Rademaker (red.), Sociologische grondberippen, deel 2, Utrecht: Spectrum, pp. 198-218.

Swanborn, P.G. (1982b), Theorie en praktijk van acht eenvoudige procedures, Meppel: Boom.

Thurman Q. (1988), Taxpayer noncompliance and attribution theory: an experimental vignette approach, Public Finance, No. 1, Vol XXXXIII. 
Velden, R. van der en B. Lodder (1993), Alternative Routes from Vocational Education to the Labour Market. Labour Market Effects of Fullime vs. Dualized Vocational Training, ROA-RM-1993/4E, Maastricht.

Velden, R. van der en B. Lodder (1995), Alternative Routes from Vocational Education to the Labour Market, Educational Research and Evaluation, Vol. 1, No. 2, pp. 109-128.

Vries, I. de en F. Heere (1993), Kosten en baten van het leerlingwezen bij bedrijven, Organisatie voor strategisch arbeidsmarktonderzoek, Den Haag.

Wittink D.R. en P. Cattin (1989), Commercial Use of Conjoint Analysis: An Update, Journal of Marketing, 53, July, pp. 91-96.

Wittink D.R., M. Vriens en W. Burhenne (1992), Commercial Use of Conjoint Analysis in Europe: Results and Critical Reflections, Working Paper, State University of Groningen.

Wolf, I. de en R. van der Velden (1999), The influence of educational characteristics in selection processes for academic jobs; an experiment among employers, Rijksuniversiteit Utrecht en Universiteit Maastricht. 


\section{Appendix: De bedrijfsenquête}

De analyses uit hoofdstuk 2 en 3 zijn gebaseerd op een telefonische enquête onder bedrijven. Deze enquête is uitgevoerd in samenwerking met het enquêtebureau NIPO op basis van de NIPO Business Monitor. De Business Monitor is een grootschalig continu onderzoek onder bedrijven. Jaarlijks worden er 20.000 bedrijfsvestingen ondervraagd. Naast algemene vragen over de bedrijfsomvang en de bedrijfssector wordt onder andere gevraagd naar zaken als de orderpositie, investeringen en personele ontwikkelingen.

In totaal zijn er 959 vestigingen in de profit en non-profit sector ondervraagd. De steekproef is disproportioneel gestratificeerd naar branche, bedrijfsgrootte en naar bedrijven met en zonder leerlingen in dienst. In de oorspronkelijke opzet was het de bedoeling om evenveel bedrijven met als zonder leerlingen in dienst te nemen. Tijdens het onderzoek bleek echter dat dit niet haalbaar was. Uiteindelijk zijn er 367 bedrijven ondervraagd met leerlingen en 592 zonder leerlingen. De gesprekken zijn gehouden met degene in het bedrijf die verantwoordelijk is voor het personeelsbeleid.

De vragenlijst omvat twee vraagblokken. In de eerste vraagblok zijn vragen opgenomen die betrekking hebben op de overwegingen die bedrijven hebben om leerlingen via de BBL dan wel stagiaires via de BOL in dienst te nemen. In het tweede vragenblok worden vragen opgenomen die betrekking hebben op de voorkeuren van werkgevers indien ze gekwalificeerd personeel op de arbeidsmarkt werven (het gaat dan om personeel dat elders is opgeleid). Hebben werkgevers in dat geval een voorkeur voor onderwijsverlaters van BOL of BBL? Getracht is om bedrijven met en zonder leerlingen zo veel mogelijk dezelfde vragen te stellen. 


\section{Vragenlijst bedrijfsenquête}

Het NIPO doet momenteel in opdracht van het Ministerie van OC en W een onderzoek onder bedrijven over de kwaliteit van de beroepsopleidingen.

1.

Kunt u mij zeggen hoeveel personen er op dit moment gewoonlijk 15 uur of meer per week bij dit bedrijf/deze vestiging werkzaam zijn? De eigenaar(s)/directeur(en) en eventuele meewerkende gezinsleden, mits 15 uur of meer per week werkzaam, dienen ook meegerekend te worden.

1. 1 persoon

2. 2 - 4 personen

3. 5 - 9 personen

4. 10 - 19 personen

5. 20 - 49 personen

6. 50 - 99 personen

7. 100 en meer personen

8. weet niet/geen opgave

2.

Werken er in dit bedrijf/deze vestiging mensen die nog in opleiding zijn en dus het werk combineren met een leerlingwezenopleiding?

1. ja

2. nee

naar vraag 36

3. weet niet/geen opgave

naar vraag 36

Indien ja

3.

Hoeveel mensen die nog in opleiding zijn en dus het werk combineren met een leerlingwezenopleiding werken op dit moment in dit bedrijf/deze vestiging?

1. geeft antwoord, namelijk à mensen

2. weet niet/geen opgave

4. Hoeveel mensen werken er in dit bedrijf/deze vestiging met een middelbare beroepsopleiding, die ze in het leerlingwezen of gewoon op school hebben afgerond? 
1. geeft antwoord, namelijk à mensen

2. weet niet/geen opgave

5.

Ik noem zo een aantal stellingen die de redenen kunnen zijn om leerlingen te hebben. Wilt $u$ aangeven welk van deze redenen voor dit bedrijf/deze vestiging belangrijk zijn?

Leerlingen zijn van belang om in de toekomst voldoende gekwalificeerd personeel in huis te hebben.

1. onbelangrijk

2. enigszins belangrijk

3. heel belangrijk

4. weet niet/geen opgave

6. Leerlingen vervullen een belangrijke rol in de bedrijfsvoering

7. Dit bedrijf/deze vestiging wil graag een bijdrage leveren aan de scholing binnen de sector.

8. Dit bedrijf/deze vestiging heeft binnen de sector afgesproken leerlingen aan te nemen.

9. Leerlingen brengen nieuwe kennis binnen in het bedrijf.

10.

Wat voor arbeidsovereenkomst hebben de leerlingen in dit bedrijf/deze vestiging meestal?

1. alleen een leercontract, maar geen arbeidscontract

2. vast contract

3. tijdelijk contract

4. contract via een speciale sectororganisatie (bijvoorbeeld de GOA)

11.

Hoe groot is de kans dat een leerling die bij dit bedrijf/deze vestiging werkt zijn diploma behaalt? Wilt u deze kans aangeven in een percentage?

1. geeft antwoord, namelijk \%

2. weet niet/geen opgave 
Indien leercontract/tijdelijk contract/contract sectororganisatie.

12.

Hoe groot is de kans dat dit bedrijf/deze vestiging een leerling na afloop van zijn opleiding een vervolgaanstelling aanbiedt, los van de vraag of de leerling deze aanstelling accepteert? Kunt $\mathrm{u}$ dit aangeven in een percentage?

1. geeft antwoord, namelijk \%

2. weet niet/geen opgave

13.

Hangt het al dan niet aanbieden van een vervolgaanstelling aan een leerling af van de behoefte aan personeel op dat moment?

1. niet

2. enigszins

3. sterk

4. weet niet/geen antwoord

14.

Hangt het al dan niet aanbieden van een vervolgaanstelling aan een leerling af van kwaliteiten van de leerling?

1. niet

2. enigszins

3. sterk

4. weet niet/geen antwoord

15.

Als dit bedrijf/deze vestiging een leerling na het behalen van het diploma een vervolgaanstelling aanbiedt, hoe groot is dan de kans dat deze ook daadwerkelijk blijft? Kunt $u$ dit aangeven in een percentage?

1. geeft antwoord, namelijk $\%$

2. weet niet/geen opgave

16.

Hoe hoog schat $u$ de productiviteit van uw leerlingen in ten opzichte van een gediplomeerde, ingewerkte werknemer? Kunt u hiervoor een percentage geven?

1. geeft antwoord, namelijk \%

2. weet niet/geen opgave 
17.

Als leerlingen al een tijdje in dit bedrijf/deze vestiging rondlopen, welk soort werk verrichten zij dan?

meerdere antwoorden mogelijk

1. in wezen hetzelfde soort werk als andere medewerkers.

2. eenvoudiger/assisterend werk.

3. taken waar ze zoveel mogelijk van kunnen leren.

4. taken waar ze goed in zijn

5. anders, namelijk ...

6. weet niet/geen opgave

18.

Is het makkelijk voor leerlingen die in dit bedrijf/deze vestiging zijn opgeleid om werk te vinden bij een ander verwant bedrijf?

1. ze vinden heel eenvoudig elders werk

2. ze vinden redelijk eenvoudig elders werk

3. het is moeilijk om elders werk te vinden

4. anders, namelijk ...

5. weet niet/geen opgave

19.

Omgekeerd, hoe eenvoudig is het voor dit bedrijf/deze vestiging om werknemers in te zetten die leerling geweest zijn bij een ander verwant bedrijf?

1. het is heel eenvoudig leerlingen van elders in te zetten

2. het is redelijk eenvoudig leerlingen van elders in te zetten

3. het is moeilijk om leerlingen van elders in te zetten

4. anders, namelijk ...

5. weet niet/geen opgave

20.

Hoeveel uur begeleiding van iedere leerling per week is er nodig door uw ervaren personeel? Het gaat hierbij om het totaal aantal uren van alle medewerkers die op de een of andere manier bij de opleiding en begeleiding betrokken zijn.

1. geeft antwoord, namelijk à uur per leerling per week

2. weet niet/geen opgave 
21.

Verdient een leerling zichzelf terug tijdens de aanstellingsperiode?

1. ruim

2. net

3. net niet

4. geheel niet

5. weet niet/geen opgave

22.

Maakt $u$ gebruik van de fiscale faciliteit of ontvangt $u$ andere subsidies vanwege het feit dat er leerlingen in dit bedrijf/deze vestiging werkzaam zijn?

1. ja

2. nee

3. weet niet/geen opgave

Indien gebruik makend van subsidies

23.

Als de subsidie op het aannemen van leerlingen met fl. 4.500,- per jaar per leerling zou stijgen, hoeveel leerlingen zou dit bedrijf/deze vestiging jaarlijks dan extra aannemen?

1. geeft antwoord, namelijk à leerlingen

2. weet niet/geen antwoord

24.

Als de subsidie die dit bedrijf/deze vestiging ontvangt weg zou vallen, hoeveel leerlingen zou dit bedrijf/deze vestiging jaarlijks dan minder aannemen?

1. geeft antwoord, namelijk à leerlingen

2. weet niet/geen antwoord

Indien niet gebruik makend van subsidies

25.

Als dit bedrijf/deze vestiging een subsidie op het aannemen van leerlingen van fl. 4.500,- per jaar per leerling zou ontvangen, hoeveel leerlingen zou dit bedrijf/deze vestiging jaarlijks dan extra aannemen?

1. geeft antwoord, namelijk à

2. weet niet/geen opgave 
26.

We willen ook iets vragen over uw mening over de kwaliteiten van afgestudeerden uit het leerlingwezen en het voltijds onderwijs.

Welke medewerkers zijn betere vakkrachten? Zijn dat medewerkers die in het leerlingwezen hebben gezeten, zijn dat medewerkers die dezelfde opleiding op school hebben gevolgd of is er geen verschil?

1. mensen uit het leerlingwezen

2. mensen van school

3. geen verschil

4. weet niet/geen opgave

27.

Welke medewerkers lossen makkelijker een nieuw en onverwacht probleem op?

Zijn dat medewerkers die in het leerlingwezen hebben gezeten, zijn dat medewerkers die dezelfde opleiding op school hebben gevolgd of is er geen verschil?

1. mensen uit het leerlingwezen

2. mensen van school

3. geen verschil

4. weet niet/geen opgave

28.

Welke medewerkers zijn meer flexibel? Zijn dat medewerkers die in het leerlingwezen hebben gezeten, zijn dat medewerkers die dezelfde opleiding op school hebben gevolgd of is er geen verschil?

1. mensen uit het leerlingwezen

2. mensen van school

3. geen verschil

4. weet niet/geen opgave

29.

Welke medewerkers leren makkelijker nieuwe dingen bij? Zijn dat medewerkers die in het leerlingwezen hebben gezeten, zijn dat medewerkers die dezelfde opleiding op school hebben gevolgd of is er geen verschil?

1. mensen uit het leerlingwezen

2. mensen van school

3. geen verschil

4. weet niet/geen opgave 
30.

Welke medewerkers zijn sneller ingewerkt? Zijn dat medewerkers die in het leerlingwezen hebben gezeten, zijn dat medewerkers die dezelfde opleiding op school hebben gevolgd of is er geen verschil?

1. mensen uit het leerlingwezen

2. mensen van school

3. geen verschil

4. weet niet/geen opgave

31.

Welke medewerkers hebben minder nascholing nodig? Zijn dat medewerkers die in het leerlingwezen hebben gezeten, zijn dat medewerkers die dezelfde opleiding op school hebben gevolgd of is er geen verschil?

1. mensen uit het leerlingwezen

2. mensen van school

3. geen verschil

4. weet niet/geen opgave

32.

Als dit bedrijf/deze vestiging onmiddellijk behoefte heeft aan een gekwalificeerde medewerker op middelbaar niveau, heeft dit bedrijf/deze vestiging dan een voorkeur voor à

1. een gediplomeerde uit het leerlingwezen

2. een gediplomeerde met een voltijds MBO-opleiding

3. voorkeur hangt sterk af van de persoon

4. anders, namelijk ...

5. weet niet/geen opgave

33.

Als dit bedrijf/deze vestiging plotseling een grote hoeveelheid werk krijgt en daardoor voor een periode van twee jaar meer personeel nodig heeft, welke medewerkers zou dit bedrijf/deze vestiging dan aan willen trekken om in deze behoefte te voorzien?

meerdere antwoorden mogelijk

1. gediplomeerden uit het leerlingwezen

2. gediplomeerden met een voltijds MBO-opleiding

3. leerlingen die nog een opleiding volgen

4. stagiaires

5. ongeschoold personeel 
6. hoger opgeleid personeel

7. anders, namelijk ...

8. weet niet/geen opgave

34.

Als het duidelijk zou worden dat dit bedrijf/deze vestiging de komende tijd gestaag zal groeien en daardoor meer personeel nodig heeft, welke medewerkers zou dit bedrijf/deze vestiging dan aan willen trekken om in deze behoefte te voorzien.

meerdere antwoorden mogelijk

1. gediplomeerden uit het leerlingwezen

2. gediplomeerden met een voltijds $\mathrm{MBO}$-opleiding

3. leerlingen die nog een opleiding volgen

4. stagiaires

5. ongeschoold personeel

6. hoger opgeleid personeel

7. anders, namelijk ...

8. weet niet/geen opgave

35.

Ten slotte, het onderzoeksinstituut ROA van de Universiteit Maastricht wil graag naar aanleiding van dit onderzoek met een aantal bedrijven een aanvullend gesprek voeren. Heeft u er bezwaar tegen als onderzoekers van het ROA contact opnemen met $\mathrm{u}$ en langskomen voor zo een gesprek van ongeveer een half uur?

1. ja, heeft bezwaar

2. nee, heeft geen bezwaar

Dit is het einde van de vragenlijst. I $\mathrm{k}$ wil $\mathrm{u}$ hartelijk bedanken voor uw medewerking en $u$ nog een prettige ochtend/middag wensen.

Indien bij vraag 2, code 2 nee, wordt de rest van de vragenlijst vervolgd

36.

Zijn in dit bedrijf/deze vestiging in een recent verleden wel mensen die nog in opleiding zijn en dus het werk combineren met een leerlingwezenopleiding werkzaam geweest?

1. ja

2. nee 
37.

Hoeveel mensen werken er in dit bedrijf/deze vestiging met een middelbare beroepsopleiding, die ze in het leerlingwezen of gewoon op school hebben afgerond?

1. geeft antwoord namelijk à medewerkers

2. weet niet/geen opgave

38.

Hieronder volgen mogelijke redenen om geen leerlingen aan te nemen. Kunt $u$ aangeven welke reden(en) voor dit bedrijf/deze vestiging van belang zijn?

Het vergt veel te veel administratie.

1. onbelangrijk

2. enigszins belangrijk

3. heel belangrijk

4. weet niet/geen opgave

39. De kosten die je maakt voor leerlingen zijn te hoog.

40. De kans dat de leerling tijdens of na afloop van de opleidingsperiode verdwijnt is te groot.

41. De voorwaarden waaraan dit bedrijf/deze vestiging moet voldoen om een erkend leerbedrijf te worden vormen een belemmering.

42. Het is moeilijk om geschikte leerlingen te vinden.

43.

Wat zouden voor dit bedrijf/deze vestiging belangrijke redenen kunnen zijn om toch leerlingen aan te nemen?

Leerlingen kunnen van belang zijn om in de toekomst voldoende gekwalificeerd personeel in huis te hebben.

1. onbelangrijk

2. enigszins belangrijk

3. heel belangrijk

4. weet niet/geen opgave

44. Leerlingen kunnen een belangrijke rol vervullen in de bedrijfsvoering.

45. Dit bedrijf/deze vestiging zouden graag een bijdrage willen leveren aan de scholing binnen de sector.

46. Leerlingen zouden nieuwe kennis binnen kunnen brengen in dit bedrijf/deze vestiging. 
47.

Als dit bedrijf/deze vestiging leerlingen zou hebben, hoe hoog schat $u$ dan de productiviteit van leerlingen ten opzichte van een gediplomeerde, ingewerkte werknemer? Kunt u hiervoor een percentage geven?

1. geeft antwoord, namelijk \%

2. weet niet/geen opgave

48.

Als dit bedrijf/deze vestiging leerlingen zou hebben, welk soort werk zou dit bedrijf/deze vestiging ze laten verrichten?

meerdere antwoorden mogelijk

1. in wezen hetzelfde soort werk als andere medewerkers

2. eenvoudiger/assisterend werk

3. taken waar ze zoveel mogelijk van kunnen leren

4. taken waar ze goed in zijn

5. anders, namelijk ...

6. weet niet/geen opgave

49.

Als dit bedrijf/deze vestiging leerlingen zou opleiden, hoe gemakkelijk zou het voor deze leerlingen zijn om werk te vinden bij een ander, verwant bedrijf?

1. ze zouden heel eenvoudig elders werk kunnen vinden

2. ze zouden redelijk eenvoudig elders werk kunnen vinden

3. het zou heel moeilijk zijn om elders werk te vinden

4. anders, namelijk

5. weet niet/geen opgave

50.

Hoe eenvoudig is het voor dit bedrijf/deze vestiging om werknemers in te zetten die leerling geweest zijn bij een ander, verwant bedrijf?

1. het is heel eenvoudig leerlingen van elders in te zetten

2. het is redelijk eenvoudig leerlingen van elders in te zetten

3. het is moeilijk om leerlingen van elders in te zetten

4. anders, namelijk

5. weet niet/geen opgave 
51.

Hoeveel uur begeleiding van iedere leerling per week schat $u$ dat er nodig zou zijn door uw ervaren personeel? Het gaat hierbij om het totaal aantal uren van alle medewerkers die op de een of andere manier bij de opleiding betrokken zijn.

1. geeft antwoord, namelijk à uur per leerling per week

2. weet niet/geen antwoord

52.

Denkt u dat een leerling zichzelf terugverdient tijdens de aanstellingsperiode?

1. ruim

2. net

3. net niet

4. geheel niet

5. weet niet/geen opgave

53.

Stel dat de subsidie op het aannemen van leerlingen met fl. 4.500,- per jaar per leerling zou stijgen, hoeveel leerlingen zou dit bedrijf/deze vestiging jaarlijks dan aan willen nemen?

1. geeft antwoord, namelijk à leerlingen

2. weet niet/geen antwoord

54.

We willen ook iets vragen over uw mening over de kwaliteiten van afgestudeerden uit het leerlingwezen en het voltijds onderwijs.

Welke medewerkers zijn betere vakkrachten? Zijn dat medewerkers die in het leerlingwezen hebben gezeten, zijn dat medewerkers die dezelfde opleiding op school hebben gevolgd of is er geen verschil?

1. mensen uit het leerlingwezen

2. mensen van school

3. geen verschil

4. weet niet/geen opgave 
55.

Welke medewerkers lossen makkelijker een nieuw en onverwacht probleem op?

Zijn dat medewerkers die in het leerlingwezen hebben gezeten, zijn dat medewerkers die dezelfde opleiding op school hebben gevolgd of is er geen verschil?

1. mensen uit het leerlingwezen

2. mensen van school

3. geen verschil

4. weet niet/geen opgave

56.

Welke medewerkers zijn meer flexibel? Zijn dat medewerkers die in het leerlingwezen hebben gezeten, zijn dat medewerkers die dezelfde opleiding op school hebben gevolgd of is er geen verschil?

1. mensen uit het leerlingwezen

2. mensen van school

3. geen verschil

4. weet niet/geen opgave

57.

Welke medewerkers leren makkelijker nieuwe dingen bij? Zijn dat medewerkers die in het leerlingwezen hebben gezeten, zijn dat medewerkers die dezelfde opleiding op school hebben gevolgd of is er geen verschil?

1. mensen uit het leerlingwezen

2. mensen van school

3. geen verschil

4. weet niet/geen opgave

58.

Welke medewerkers zijn sneller ingewerkt? Zijn dat medewerkers die in het leerlingwezen hebben gezeten, zijn dat medewerkers die dezelfde opleiding op school hebben gevolgd of is er geen verschil?

1. mensen uit het leerlingwezen

2. mensen van school

3. geen verschil

4. weet niet/geen opgave 
59.

Welke medewerkers hebben minder nascholing nodig? Zijn dat medewerkers die in het leerlingwezen hebben gezeten, zijn dat medewerkers die dezelfde opleiding op school hebben gevolgd of is er geen verschil?

1. mensen uit het leerlingwezen

2. mensen van school

3. geen verschil

4. weet niet/geen opgave

60.

Als dit bedrijf/deze vestiging onmiddellijk behoefte heeft aan een gekwalificeerde medewerker op middelbaar niveau, heeft dit bedrij/deze vestiging dan een voorkeur voor à

1. een gediplomeerde uit het leerlingwezen

2. een gediplomeerde met een voltijds MBO-opleiding

3. voorkeur hangt sterk af van de persoon

4. anders, namelijk ...

5. weet niet/geen opgave

61.

Als dit bedrijf/deze vestiging plotseling een grote hoeveelheid werk krijgt en daardoor voor een periode van twee jaar meer personeel nodig heeft, welke medewerkers zou dit bedrijf/deze vestiging dan aan willen trekken om in deze behoefte te voorzien

meerdere antwoorden mogelijk

1. gediplomeerden uit het leerlingwezen

2. gediplomeerden met een voltijds MBO-opleiding

3. leerlingen die nog een opleiding volgen

4. stagiaires

5. ongeschoold personeel

6. hoger opgeleid personeel

7. anders, namelijk ...

8. weet niet/geen opgave 
62.

Als het duidelijk zou worden dat dit bedrijf/deze vestiging de komende tijd gestaag zal groeien en daardoor meer personeel nodig heeft, welke medewerkers zou dit bedrijf/deze vestiging dan aan willen trekken om in deze behoefte te voorzien.

meerdere antwoorden mogelijk

1. gediplomeerden uit het leerlingwezen

2. gediplomeerden met een voltijds MBO-opleiding

3. leerlingen die nog een opleiding volgen

4. stagiaires

5. ongeschoold personeel

6. hoger opgeleid personeel

7. anders, namelijk ..

8. weet niet/geen opgave

63.

Ten slotte, het onderzoeksinstituut ROA van de Universiteit Maastricht wil graag naar aanleiding van dit onderzoek met een aantal bedrijven een aanvullend gesprek voeren. Heeft $u$ er bezwaar tegen als onderzoekers van het ROA contact opnemen met $u$ en langskomen voor zo een gesprek van ongeveer een half uur?

1. ja, heeft bezwaar

2. nee, heeft geen bezwaar

Dit is het einde van de vragenlijst. I $\mathrm{k}$ wil $\mathrm{u}$ hartelijk bedanken voor uw medewerking en $u$ nog een prettige ochtend/middag wensen. 
